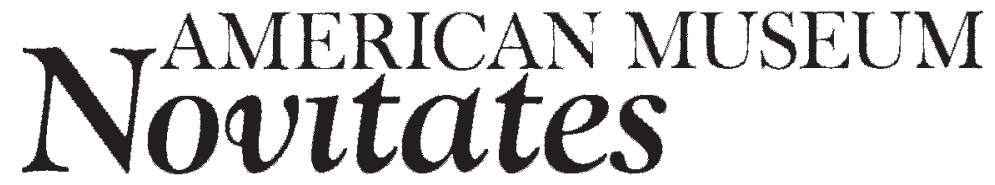

PUBLISHED BY THE AMERICAN MUSEUM OF NATURAL HISTORY CENTRAL PARK WEST AT 79TH STREET, NEW YORK, NY 10024 Number 3622, 46 pp., 14 figures, 8 tables

August 28, 2008

\title{
Systematic Review of Genus Cerradomys Weksler, Percequillo and Voss, 2006 (Rodentia: Cricetidae: Sigmodontinae: Oryzomyini), with Description of Two New Species from Eastern Brazil
}

\author{
ALEXANDRE R. PERCEQUILLO, ${ }^{1}$ ERIKA HINGST-ZAHER, ${ }^{2}$ AND \\ CIBELE R. BONVICINO ${ }^{3}$
}

\begin{abstract}
Cerradomys is a monophyletic genus that includes four known species, Cerradomys subflavus, $C$. maracajuensis, C. marinhus, and C. scotti, distributed throughout the open vegetation belt across South America, from northeastern Brazil to southeastern Bolivia, and from eastern to northwestern Paraguay. We revised the status of the species currently assigned to this genus by analyzing skins, skulls, karyotypes, and cytochrome $b$ DNA sequences. We also described two novel species, one distributed in the Brazilian states of Minas Gerais, Bahia, and Sergipe, and the other in the states of Paraíba, Pernambuco, Piauí, Ceará, and Maranhão. Molecular analysis suggested the following phylogenetics arrangement: (( $C$. subflavus $-C$. sp.n.2) $C$. sp.n.1) $C$. scotti)(C. marinhus-C. maracajuensis)). Apparently, both novel species inhabit the Caatinga domain and penetrated the coastal Atlantic rainforest, differing from the remaining congeneric species that are typical open-area inhabitants.
\end{abstract}

\section{RESUMO}

O gênero Cerradomys é uma entidade monofilética que reúne quatro espécies, Cerradomys subflavus, C. maracajuensis, C. marinhus, e C. scotti, distribuídas através do cinturão de vegetação

\footnotetext{
${ }^{1}$ Departamento de Ciências Biológicas, Escola Superior de Agricultura "Luiz de Queiroz", Universidade de São Paulo, Avenida Pádua Dias, 11, C.P. 9, 13418-900, Piracicaba, SP, Brazil (percequi@esalq.usp.br).

${ }^{2}$ Laboratório de Morfometria, Mastozoologia, Museu de Zoologia da Universidade de São Paulo, C.P. 42594, 04299 970, São Paulo, SP, Brazil (hingstz@usp.br).

${ }^{3}$ Programa de Genética, Instituto Nacional de Câncer, Rua André Cavalcanti, 37, 4th floor, 20231-050, Rio de Janeiro, Brazil and Laboratório de Biologia e Parasitologia de Mamíferos Silvestres Reservatórios, Instituto Oswaldo Cruz, Rio de Janeiro, Brazil (cibelerb@inca.gov.br).
} 
seca que divide a América do Sul do nordeste do Brasil ao sudeste da Bolívia e noroeste do Paraguai. Baseados no estudo de peles, crânios, cariótipos e seqüências de nucleotídeos de ADN, nós revisamos as espécies atualmente atribuídas ao gênero e reconhecemos duas espécies novas, cujas distribuições estão atualmente limitadas aos estados brasileiros de Minas Gerais, Bahia e Sergipe, e aos estados de Paraíba, Pernambuco, Piauí, Ceará e Maranhão, respectivamente. Análises moleculares empregando algoritmos de parcimônia sugerem o seguinte padrão de adjacência entre seis táxons terminais: $(((C$. subflavus $-C$. sp.n. 2) $C$. sp.n.1) $C$. scotti $)(C$. marinhus C. maracajuensis)). Aparentemente, as novas espécies são habitantes típicas da Caatinga, que penetram marginalmente na Floresta Atlântica costeira do nordeste do Brasil, diferindo das demais espécies do grupo que são típicas formas de áreas abertas.

\section{INTRODUCTION}

Oryzomyini (sensu Weksler, 2006; Weksler et al., 2006) is a diverse and ubiquitous tribe, with 26 genera in South America, ranging from northern Colombia to northern Argentina, inhabiting cis-Andean and trans-Andean lowland and highland forests, montane forests, dry forests, savannas, grasslands, scrubs, and coastal marshes (Musser and Carleton, 2005; Weksler et al., 2006).

Several reports on the systematic of this tribe, with emphasis on the traditional conception of the polyphyletic genus Oryzomys (Musser and Carleton, 2005), resulted in more accurate definitions of genera, species group, and species in the past decade (Weksler, 1996; Musser et al., 1998; Percequillo, 1998, 2003; Bonvicino and Moreira, 2001; Langguth and Bonvicino, 2002; Musser and Carleton, 2005; Weksler, 2003, 2006). These studies led to the recent division of Oryzomys species groups in 10 new oryzomyine genera: Aegialomys, Cerradomys, Eremoryzomys, Euryoryzomys, Hylaeamys, Mindomys, Nephelomys, Oreoryzomys, Sooretamys and Transandinomys (Weksler et al., 2006). However, the species group taxa in several of these genera still remain taxonomically unresolved, with undescribed forms and poorly diagnosed species.

Recently, the genus Cerradomys (formerly Oryzomys subflavus group) has been extensively studied by morphologic, karyologic, and molecular approaches (Bonvicino et al., 1999; Bonvicino and Moreira, 2001; Langguth and Bonvicino, 2002; Bonvicino, 2003; Brooks et al., 2004). These studies allowed for the recognition and description of four new species, considerably altering the species diversity in a group known to include only $C$. subflavus until 2002.

Currently, the genus Cerradomys comprises four species, namely: C. maracajuensis Lang- guth and Bonvicino, 2002; C. marinhus Bonvicino, 2003; C. scotti Langguth and Bonvicino, 2002 (including Cerradomys andersoni Brooks et al. 2004; see Emmons et al., 2006); and C. subflavus (Wagner, 1842). The monophyly of this group has been demonstrated in several molecular studies (Bonvicino and Moreira, 2001; Bonvicino, 2003; Brooks et al., 2004), which included cytochrome $b$ DNA haplotypes of all known taxa.

Cerradomys species are distributed throughout an open-vegetation belt, also known as the dry diagonal corridor of South America (Costa, 2003; Bonvicino, 2003). This openvegetation area crosses South America from northeastern Brazil to southeastern Bolivia and northwestern Paraguay, including the Caatinga, Cerrado, and Chaco domains (Costa, 2003).

According to morphologic (Percequillo, 1998), karyologic (Maia and Hulak, 1981; Almeida and Yonenaga-Yassuda, 1985; Svartman and Almeida, 1992; Bonvicino et al., 1999; Andrades-Miranda et al, 2002), and molecular evidence (Bonvicino and Moreira, 2001, Bonvicino, 2003), Cerradomys was considered very diverse, still presenting undescribed forms (see Bonvicino and Moreira, 2001; Bonvicino, 2003). Here we review the current recognized species of genus Cerradomys and describe two new species from eastern Brazil, based on morphologic, morphometric, and karyologic evidence. Moreover, we also show the phylogenetic relationship within Cerradomys based on cytochrome $b$ DNA sequence data.

\section{MATERIAL AND METHODS}

SPecimens: We studied skins, skulls, skeletons, and fluid-preserved specimens deposited in the following collections: 
AMNH American Museum of Natural History, New York

APC uncatalogued specimens collected by Ana Paula Carmingnotto (MZUSP)

ARP uncatalogued specimens collected by Alexandre Reis Percequillo (MZUSP)

BMNH The Natural History Museum, London

CBF Coleccion Boliviana da Fauna, La $\mathrm{Paz}$

CRB uncatalogued specimens collected by Cibele R. Bonvicino (MN)

FMNH The Field Museum, Chicago

GD uncatalogued specimens collected by Guillermo D'Elía (MHNM)

JD uncatalogued specimens collected by Julio Dalponte (UFMT)

LPC uncatalogued specimens collected by Leonora Pires Costa (UFMG)

LV Laboratório de Vertebrados, UFRJ, Rio de Janeiro

MHNM Museo de Historia Natural de Montevideo, Montevideo

MLP Museo La Plata, La Plata

MN Museu Nacional da Universidade Federal do Rio de Janeiro, Rio de Janeiro

MVZ Museum of Vertebrate Zoology, Berkeley

MW uncatalogued specimens collected by Marcelo Weksler (MN)

MZUSP Museu de Zoologia da Universidade de São Paulo, São Paulo

RM uncatalogued specimens collected by Raquel Moura (UFMG)

RP uncatalogued specimens collected by Renata Pardini (MZUSP)

UFMG Departamento de Zoologia da Universidade Federal de Minas Gerais, Belo Horizonte

UFMT Universidade Federal de Mato Grosso, Cuiabá

UFPB Departamento de Sistemática e Ecologia, Universidade Federal da Paraíba, João Pessoa

UMMZ University of Michigan, Museum of Zoology, Ann Arbor

UnB Departamento de Zoologia, Universidade de Brasília, Distrito Federal

USNM National Museum of Natural History, Washington, DC

YL uncatalogued specimens collected by Yuri Leite (UFMG)

A gazetteer of collecting localities is furnished in appendix 1 .

Lists of specimens examined are provided in the species account, along with species de- scriptions with synonymy, type locality, geographic distribution, diagnosis, karyology, and natural history. Uppercase letters preceding museum number refer to sex of voucher specimens, $\mathrm{M}$ for males, $\mathrm{F}$ for females and $\mathrm{I}$ for nonsexed specimens. Lists of examined specimens are arranged in alphabetical order, by country, state or province, and locality of collection.

External and Cranial Measurements: All measurements are expressed in millimeters $(\mathrm{mm})$ except weight, which is expressed in grams (g). The following external measurements were obtained from specimen tags or from wild-caught specimens during fieldwork:

$\begin{array}{ll}\text { TL } & \text { Total length } \\ \text { LT } & \text { Length of the tail } \\ \text { Ear } & \text { Pinnae length } \\ \text { HF } & \text { Length of hind foot } \\ \text { Wt } & \text { Weight }\end{array}$

Head-and-body length (HBL) was obtained by subtracting length of tail from total length.

Fifteen cranial measurements (based on Langguth, 1963; Voss, 1988; Brandt and Pessôa, 1994; Musser et al., 1998) were obtained with digital calipers, to the nearest $0.01 \mathrm{~mm}$ :

CIL Condylo-incisive length, measured from the greater curvature of one upper incisor to the articular surface of the occipital condyle on the same side

LD Length of diastema, from the crown of the first upper molar to the lesser curvature of the upper incisor on the same side

LM Length of molars, crown length from M1 to M3

BM1 Breadth of M1, greatest crown breadth of the first maxillary molar across the paracone-protocone

LIF Length of incisive foramen, greatest anterior-posterior dimension of one incisive foramen

PB Palatal breadth, measured at the labial margin of maxillary bone across the third molars

BR Breadth of rostrum, greatest dimension measured across the external border of the nasolacrimal capsules

LN Length of nasals, greatest anteriorposterior dimension of one nasal bone

LPB Length of palatal bridge, measured from the posterior border of the 
incisive foramen to the anterior border of the mesopterygoid fossa

$\mathrm{HB}$ Height of braincase, greatest height of braincase, measured from the sphenoccipital suture to the frontoparietal suture

LIB Least interorbital breadth, least distance across the frontal bones

ZB Zygomatic breadth, greatest dimension across the squamosal root of zygomatic arches

CZL Condylo-zygomatic length, measured from the occipital condyle to the posteriormost edge of the zygomatic notch

OFL Orbital fossa length, greatest length of the orbital fossa between the squamosal and maxillary roots of the zygomatic arch

$\mathrm{BB}$

Bullar breadth, greatest breadth from the petrosal-basioccipital suture to the dorsal process of the ectotympanic

Age Criteria and Anatomy: We followed the terminology and definitions employed by Musser et al. (1998) for age classes, and those defined by Carleton (1973), Reig (1977), Voss (1988, 1993), Voss and Carleton (1993), Steppan (1995), Voss et al. (2001), and Weksler (2006) for the external and cranial measurements, anatomical traits, and molar nomenclature.

Statistical Analyses: We quantitatively compared adults from all species assigned to Cerradomys. Univariate comparisons among the $C$. subflavus and the two new species were performed through one-way analysis of variance (one-way ANOVA) of body and skull measurements. Principal components analysis was also performed, using the 15 log-transformed cranial measurements and the covariance matrix. We explored morphometric differentiation among the three species through a discriminant analysis of the logtransformed cranial measurements. Statistical procedures are detailed in Neff and Marcus (1980) and Sokal and Rohlf (1995). All the reported results were obtained using SAS v.8.02.

Cytogenetics: Chromosome preparations were obtained from short-term cell cultures. Bone marrow was directly cultured for two hours (around $37^{\circ} \mathrm{C}$ ) in Falcon tubes containing sterile medium ( $80 \%$ RPMI, $20 \%$ fetal calf serum, $5 \mu \mathrm{g} / \mathrm{ml}$ of ethidium bromide and $10^{-6}$
M colchicine). G-banding was carried out for identifying chromosomal homologies as descriced by Seabright (1971). Chromosomes were ordered according to morphology and decreasing size.

Phylogenetic Analysis: Phylogenetic reconstructions were carried out with DNAsequence data of the mitochondrial gene cytochrome $b$. We analyze the two new species herein described (GenBank accession number AF181275, museum specimens MN 35898 and LV-FC 148; and AF181276, museum specimen MN 96786 [AL 3655]), plus C. scotti (AF181277-comprising specimens MN50379 and MN61677 sharing the same haplotype), C. maracajuensis (AF181278 - MN44178), C. marinhus (AF181278 - MN63824) and $C$. subflavus (AF181274 - CEG42), Nectomys squamipes (AF181283 - MN42685), Nectomys garleppii (U03539 - MVZ166700), and Sooretamys angouya (AF181281 - CRB1273). Neotoma albigula (AF108704 - MVZ 147667) and Scotinomys teguina (AF108705 - UMMZ 3373) were used as outgroups. Cerradomys andersoni could not be included in the present analyses due to lack of available nucleotide sequence data in GenBank.

MEGA 3.1 (Kumar et al., 1993) was used to estimate $p$ distances between haplotypes. Parsimony analysis was carried out by branch-and-bound search, with all characters equally weighted. Bootstrap values were estimated on the basis of 1,000 replicates (PAUP* 4.0, Swofford, 2003).

\section{TAXONOMIC ACCOUNTS}

Cerradomys Weksler, Percequillo and Voss, 2006

Type Species: Hesperomys subflavus Wagner, 1842.

Contents: Cerradomys maracajuensis Langguth and Bonvicino, 2002; Cerradomys marinhus Bonvicino, 2003; Cerradomys scotti Langguth and Bonvicino, 2002 (including $C$. andersoni, Brooks et al., 2004); Cerradomys subflavus (Wagner, 1842); and two new species below described (see Comments).

Geographic Distribution: Species attributed to Cerradomys are usually associated to the diagonal belt of open and drier vegetation formed mainly by the Chaco, 
Cerrado, Pantanal, and Caatinga biomes, from northeastern Brazil to eastern Paraguay and central Bolivia (figs. 1, 2). In northeastern Brazil, from Bahia to Paraíba states, there are also samples associated with coastal Atlantic Forest.

Diagnosis: Cerradomys species exhibit a long, dense, lax, and coarsely grizzled dorsal pelage (wool hairs: 6-12 $\mathrm{mm}$; cover hairs: 9$17 \mathrm{~mm}$; guard hairs: 13-22 $\mathrm{mm}$ ); tail longer than head and body length combined (110\%$123 \%$ of head and body length); incisive foramina very long, with lateral margins wider medially and anteroposterior margins sharp; interorbital region strongly convergent anteriorly, with well-developed supraorbital crests; complex posterolateral palatal pits recessed at very deep and wide fossae (except in Cerradomys maracajuensis and C. marinhus); long and wide sphenopalatine vacuities present (except in Cerradomys maracajuensis and C. marinhus); stapedial foramen and posterior opening of alisphenoid canal absent or small, squamosal-alisphenoid groove and sphenofrontal foramen absent, and secondary branch crosses dorsal surface of pterygoid plate (pattern 3 of Voss, 1988); capsular process of lower incisor present; phallus with reduced cartilaginous baculum, two-digitated, with central digit absent; cartilaginous baculum situated outside the glans penis body; bony baculum extremely elongated; length of cartilaginous baculum about $1 / 8$ of the length of osseous baculum (for more diagnostic traits, see also Weksler et al., 2006).

Morphological Description: Large body size (HBL range, $119-185 \mathrm{~mm} ; \mathrm{n}=305$ ) and tail much longer than head and body length (TL range, 131-227 mm; $\mathrm{n}=297$ ); hind-feet robust, presenting a considerable span of size (HFL range, $20-43 \mathrm{~mm}$ in length; $\mathrm{n}=314$ ). Pinnae small (ear range, $15-27 \mathrm{~mm} ; \mathrm{n}=321$ ). Dorsal pelage variably short to long, and dense; wool hairs thin, long and wavy (range: 5-12 mm); cover hairs longer and thicker on distal half (range, 9-17 mm); guard hairs much longer, stiffer, and thicker on its distal third (range, 13-22 $\mathrm{mm}$ ). Dorsal body pelage uniform from head to rump, coarsely grizzled, varying from buffy yellow grizzled with dark brown to buffy orange-red grizzled with black; in some species, head distinctly colored from body (head grayish and body orange to reddish, in $C$. subflavus and the two new species). Ventral pelage short composed by wool, cover and guard hairs (similar, but shorter to dorsal hairs). Ventral pelage ranges from white to buff grizzled with gray (ventral hairs always gray-based). Body flanks buffy yellow to reddish orange. Mystacial vibrissae very dense and long, barely surpassing the ears when laid back; dorsal mystacial vibrissae dark brown with golden tips and ventral entirely white. Tail covered by short hairs (apparently almost naked) or long hairs (hirsute); tail uniformly colored (C. marinhus and $C$. maracajuensis), weakly bicolored $(C$. subflavus) or distinctly bicolored (C. scotti). Dorsal surface of hindfoot densely covered by short hairs; ungual tufts dense, not concealing the claws. Pinnae small, densely covered by short hairs, both internally and externally; pinnae hairs brown, with buffy or orange tips. Four pairs of mammae present, in inguinal, abdominal, postaxial, and pectoral positions.

Skull large and robust (figs. 3-6; CIL range, 28.4-36.6 mm; $\mathrm{n}=313$ ). Rostrum long and broad, tapering, flanked by shallow to deep and wide zygomatic notch; rostral fossae moderately to deeply excavated; premaxillae short, not produced anteriorly (not forming with nasals a rostral tube); nasals long, tapering posteriorly, not extending posteriorly beyond lacrimals; interorbital region strongly converging anteriorly, with well-developed supraorbital crests, forming a distinctly projecting shelf; braincase oblong, with temporal crest developed; interparietal broad, nearly equaling caudal border of parietals; lambdoidal crests well developed and sharp, and occipital region with developed occipital crests. Zygomatic plate (in lateral view) with anterior margin straight or slightly concave; zygomatic spine present in some individuals of some species (e.g., C. maracajuensis), but predominantly rounded in shape; zygomatic plate ranging from narrow to broad (BZP range, $2.8-4.4 \mathrm{~mm} ; \mathrm{n}=344)$. Zygomatic arches strong and slightly divergent posteriorly; jugal present (separating the maxillary and squamosal ramus of zygomatic arch). Incisive foramina very long (LIF range, $6.1-8.6 \mathrm{~mm}$; $\mathrm{n}$ $=344$; occupying ca. $75 \%$ of the length of diastema in all species), with lateral margins 


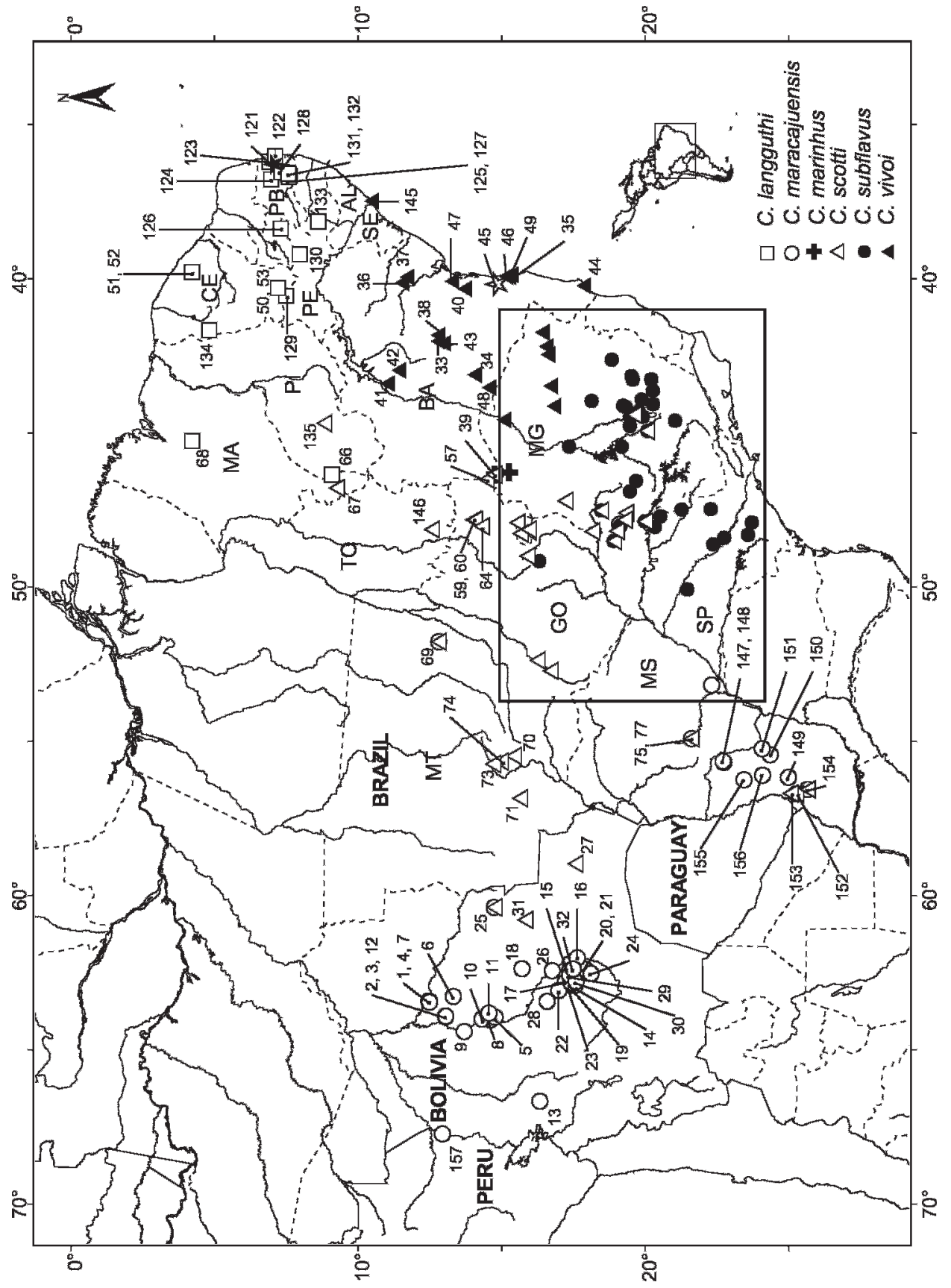

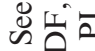

ก․․

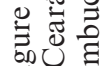

曰山ी

胥茪

च

ฯ 近雪

胥 î

ซ $\cos _{0} \frac{n}{2}$

ถిष

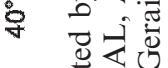

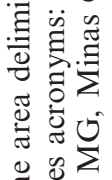

F离苛

롤 윰

选空

至

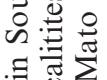

$\lesssim$ 응

ई $\Sigma$

는

ड

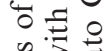

$\frac{0}{0} \bar{z}$

号总

希

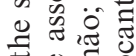

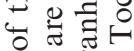

包离离

芯忐这司

๐ี

包椞

8 - 00

כ드

寻芯造

$\therefore \stackrel{\overline{8}}{\circ} 0$

的芒芯 


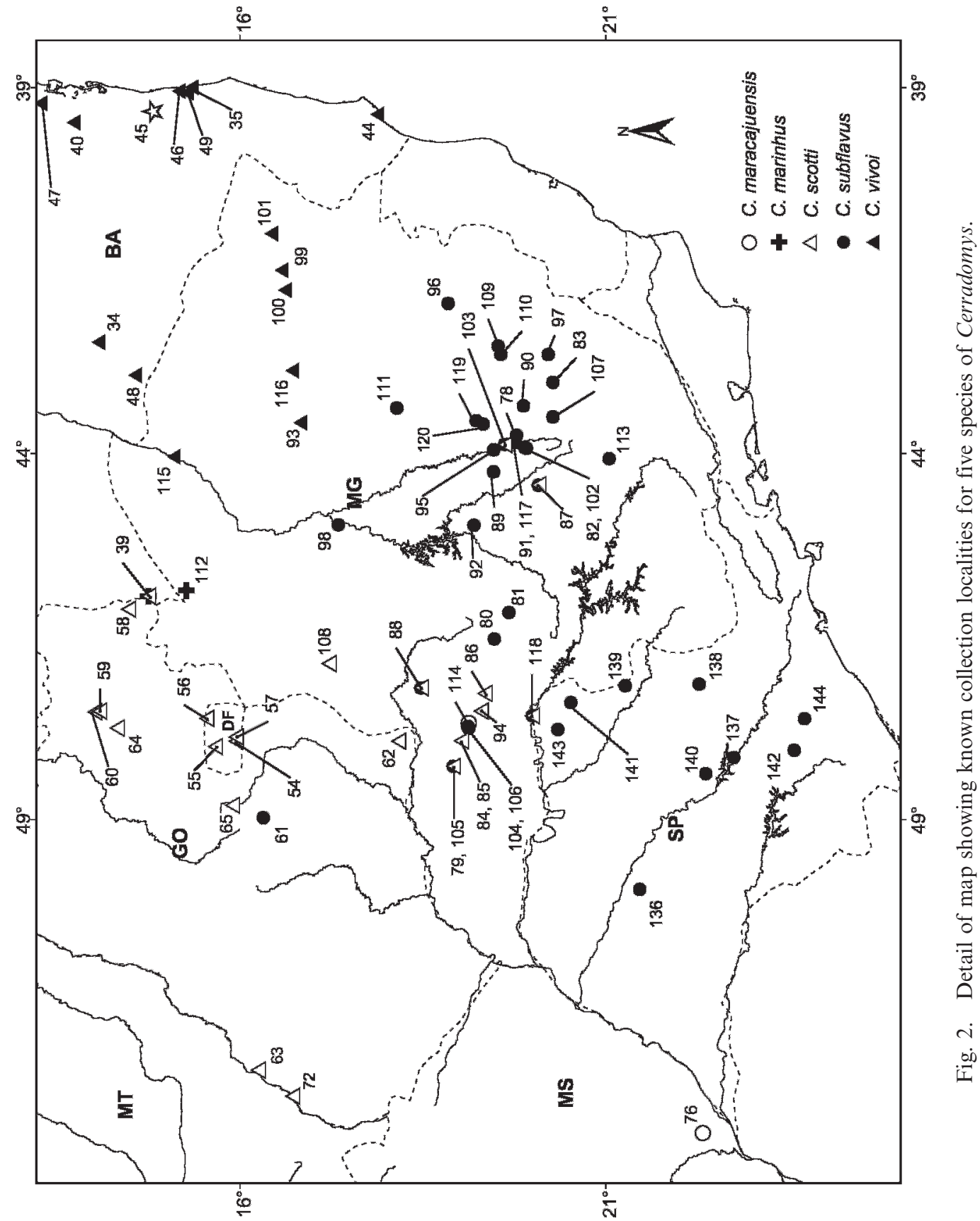




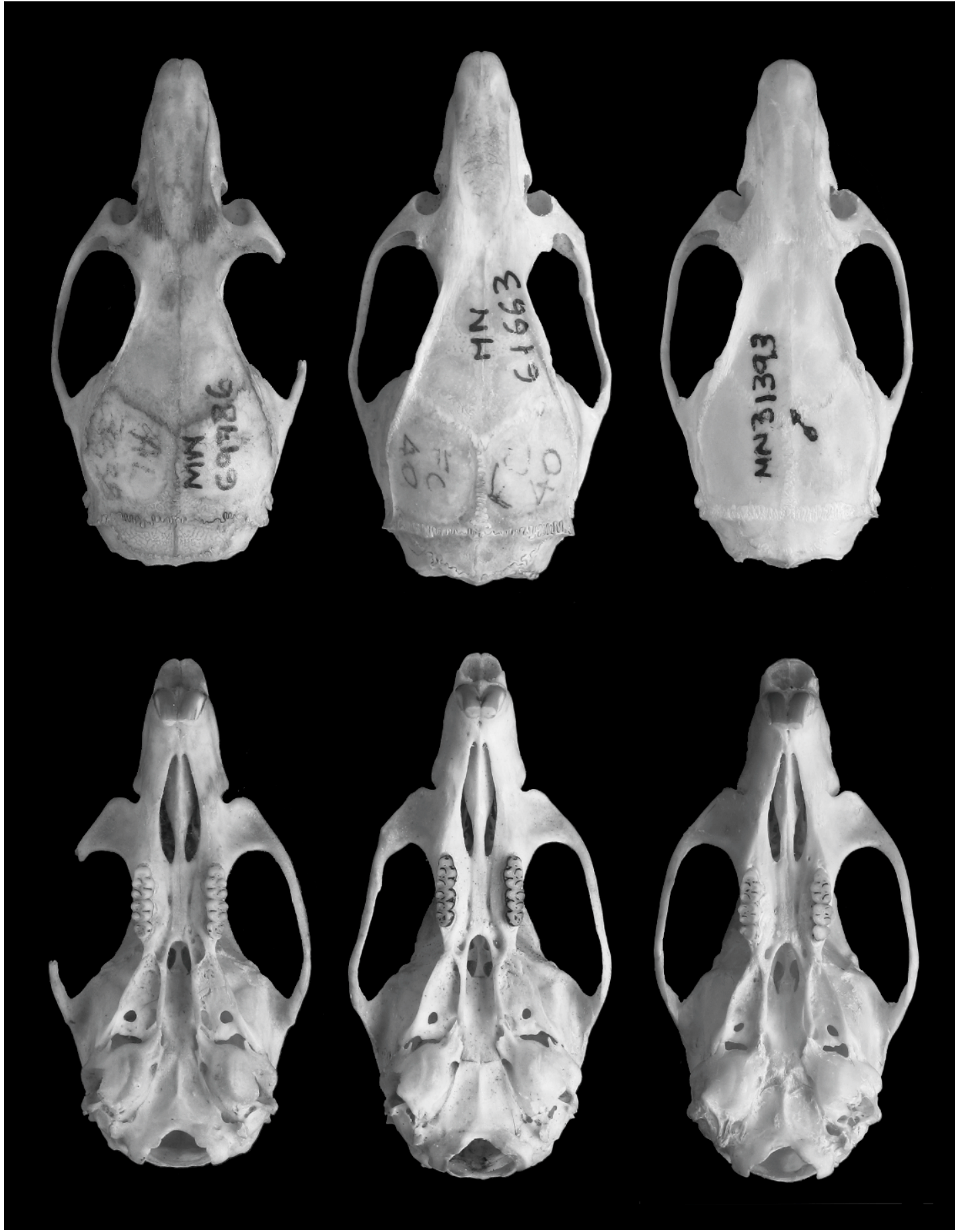

Fig. 3. Dorsal and ventral cranial views of three species of Cerradomys. Left: C. langguthi from Corredor São João-Fazenda Pacatuba, Paraíba (MN 69786; CIL, $32.1 \mathrm{~mm}$ ). Middle: C. vivoi from Fazenda Canoas, Juramento, Minas Gerais (MN 61663; CIL, 32.92 mm). Right: C. subflavus from Parque Nacional da Serra do Cipó, Minas Gerais (MN 31393; CIL, $32.41 \mathrm{~mm}$ ). 


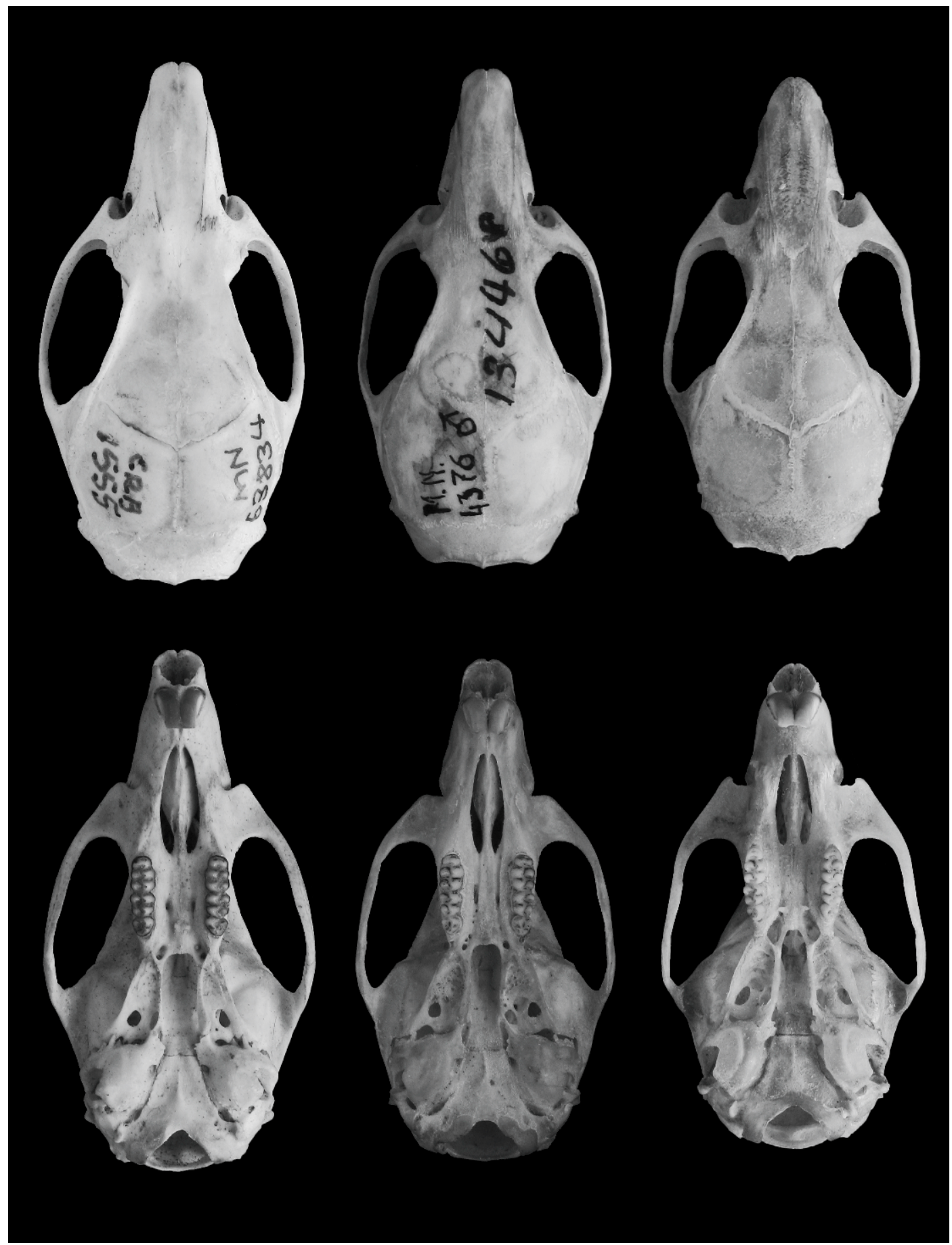

Fig. 4. Dorsal and ventral cranial views of three species of Cerradomys. Left: C. marinhus from Fazenda Sertão do Formoso, Jaborandi (MN 63834; CIL, 33.39 mm). Middle: C. maracajuensis from Maracaju, Mato Grosso do Sul (MN 4376; CIL, 30.83 mm). Right: C. scotti from Estação Ecológica Santa Bárbara, São Paulo (MZUSP APC 1157; CIL, 31.38 mm). 


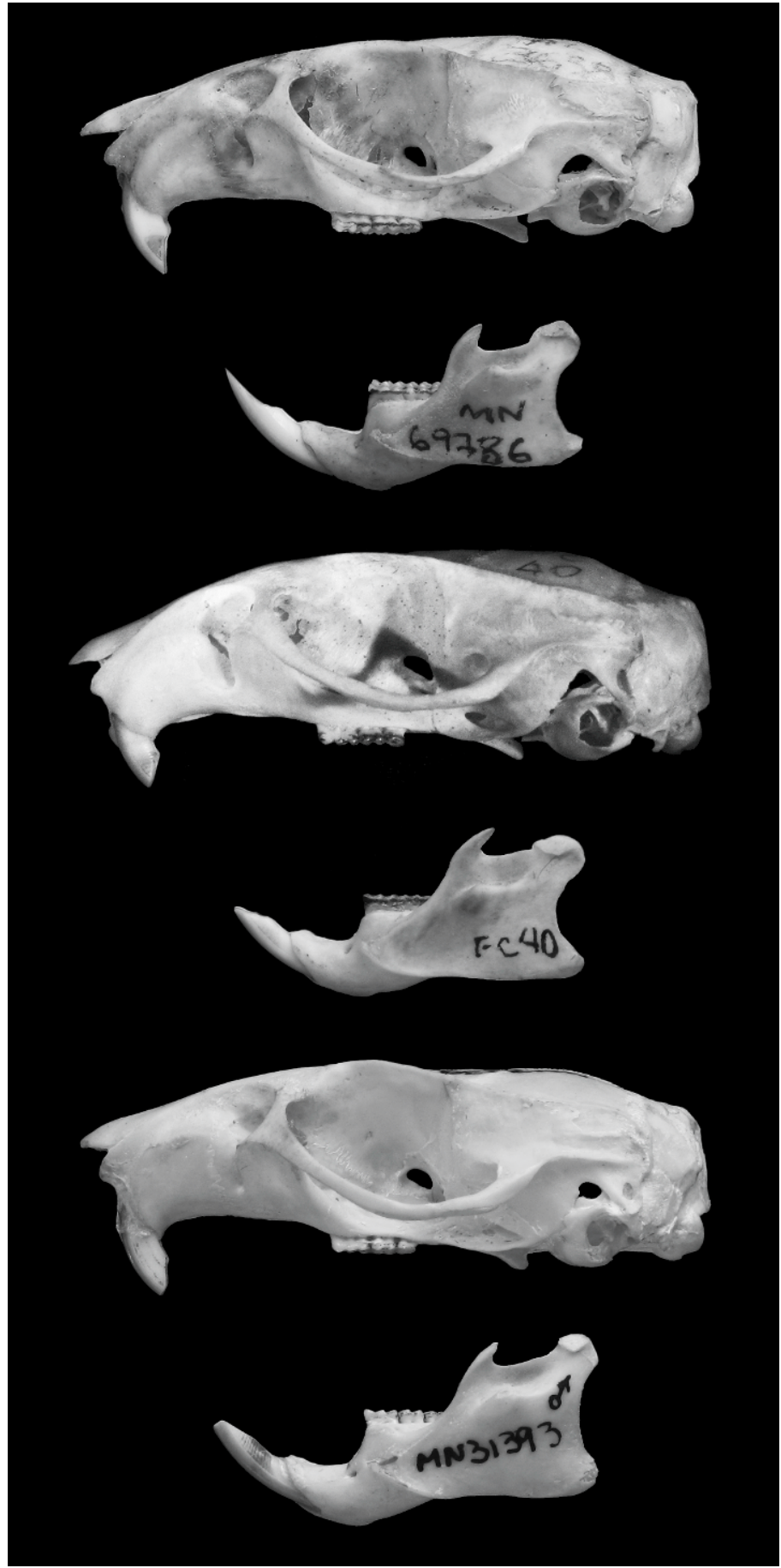

Fig. 5. Lateral cranial and mandible views of three species of Cerradomys. Top: C. langguthi from Corredor São João-Fazenda Pacatuba, Paraíba (MN 69786; CIL, $32.1 \mathrm{~mm}$ ). Middle: C. vivoi from Fazenda Canoas, Juramento, Minas Gerais (MN 61663; CIL, $32.92 \mathrm{~mm}$ ). Bottom: C. subflavus from Parque Nacional da Serra do Cipó, Minas Gerais (MN 31393; CIL, $32.41 \mathrm{~mm}$ ). 


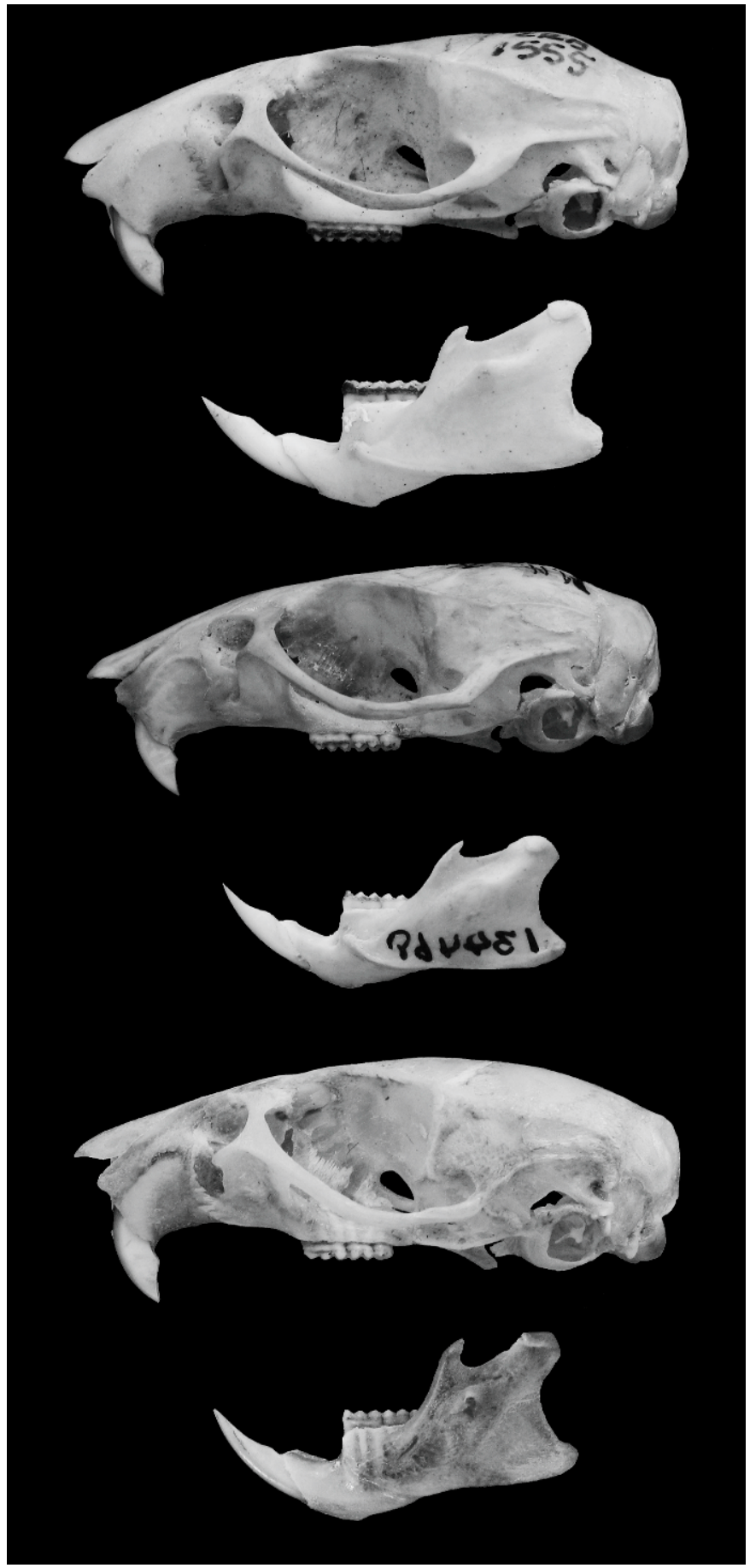

Fig. 6. Lateral cranial and mandible views of three species of Cerradomys. Top: C. marinhus from Fazenda Sertão do Formoso, Jaborandi (MN 63834; CIL, $33.39 \mathrm{~mm}$ ). Middle: C. maracajuensis from Maracaju, Mato Grosso do Sul (MN 4376; CIL, $30.83 \mathrm{~mm}$ ). Bottom: C. scotti from Estação Ecológica Santa Bárbara, São Paulo (MZUSP APC 1157; CIL, 31.38 mm). 
wider medially and anteroposterior margins round to acute; posterior margins of incisive foramina extending to or between M1 alveoli (not extending in some individuals of some species; e.g., C. scotti). Palate with complex posterolateral palatal pits located on deep (in C. maracajuensis and C. marinhus) to very deep and wide palatal notches; palatal excrescences variably present. Mesopterygoid fossa narrow to wide; anterior border of mesopterygoid fossa reach the alveolus of M3 in younger individuals (but this condition persists in some adults of some species); bony roof of fossa completely ossified or perforated by small to very large sphenopalatine vacuities present. Parapterygoid plates wide and moderately excavated, without vacuities or fontanelles. Alisphenoid strut variably present (buccinator-masticatory and accessory oval foramina confluent [in $C$. scotti] or not). Carotid arterial circulation derived, with stapedial foramen and posterior opening of alisphenoid canal absent or small, squamosalalisphenoid groove and sphenofrontal foramen absent, and secondary branch crosses dorsal surface of pterygoid plate (pattern 3 of Voss, 1988). Posglenoid foramen large and rounded to small and narrow; subsquamosal fenestra variably small, vestigial, or absent; hamular process of squamosal wide (indistinct in specimens with obliterated subsquamosal fenestra). Tegmen tympani short, overlapping squamosal or not; posterior suspensory process of squamosal absent. Auditory bulla globose; eustachian tube short to medium, with or without a distinct medial bony lamina dorsal to carotid canal; bony process dorsal to stapedial process of ectotympanic present, overlapped or not to squamosal.

Mandible robust (figs. 5, 6); coronoid process developed, falciform to triangular, nearly equal in height to condyloid process; superior notch shallow; angular process short, variably surpassing the condyloid process posteriorly; inferior notch shallow; capsular projection of lower incisor is present (in adult specimens).

Incisors opisthodont; anterior enamel surface orange. Molars pentalophodont, lowcrowned; main cusps arranged in opposite pairs; labial and lingual flexi overlap at median molar plane. M1 with paracone connected medially to protocone (defining a long and obliquely oriented parafossetus); mesoloph long and narrow; metacone posteromedially connected to posteroloph; posteroloph long and narrow. M2 similar to M1; paracone connected medially to protocone; metacone connected medially and posteromedially to posteroloph; mesolph long and narrow in most species or reduced/absent in other $(C$. scotti and few individuals of $C$. maracajuensis); posteroloph long and narrow. M3 small, with metacone-hypocone pair reduced; mesoloph fused to metacone; deep and well-defined hypoflexus. Lower $\mathrm{m} 1$ with narrow and undivided anteroconid; protolophid and mesolophid narrow (fusing to anterolingual conulid, entoconid with slight wear, respectively). $\mathrm{m} 2$ similar to $\mathrm{m} 1$; anterolabial cingulum well developed; protoflexid deep; mesolophid long and narrow in most species, reduced or absent in others $(C$. scotti and $C$. maracajuensis). $\mathrm{m} 3$ with anterolabial cingulum weakly developed; protoflexid shallow. M1 with four roots, one anterior, one posterior and two accessory rootlets, in labial and lingual positions; M2 and M3 with three roots. $\mathrm{m} 1$ with two roots and two accessory rootlets; $\mathrm{m} 2$ and $\mathrm{m} 3$ with two roots.

Postcranial axial skeleton formed by 7 cervical, 12 toraxic, 7 lumbar, 3-4 sacral, and 33-37 caudal vertebrae (modal number 36); fifth lumbar vertebrae variably present anapophysis, small or large; hemal arches with conspicuous posterior process variably on vertebrae $1 / 2,2 / 3,3 / 4$, and $4 / 5$.

Stomach unilocular and hemiglandular (sensu Carleton, 1973), without extension of glandular epithelium into corpus. Phallus elongate and narrow (fig. 7); distal cartilaginous baculum extremely reduced, central digit reduced or absent (two-digitated); cartilaginous baculum situated outside the glans penis body; bony baculum extremely elongated (length of cartilaginous baculum about $1 / 8$ of the length of osseous baculum). Urethral ventral flaps absent; urethral processes without subapical lobules; dorsal papilla spineless; small spines densely ornament the phallus epidermis.

COMPARISONS: For detailed comparisons with other Oryzomyini genera, see Weksler et al. (2006).

Comments: In addition to the four nominal taxa presently assigned to Cerradomys, 

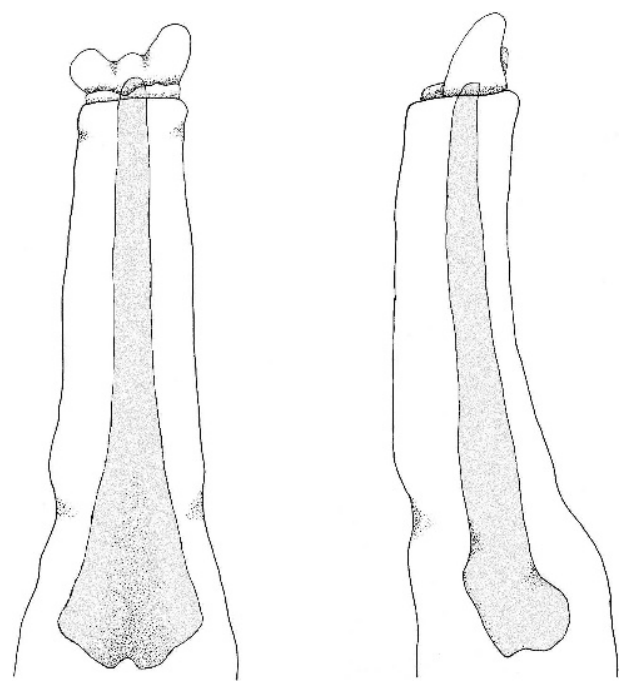

Fig. 7. Ventral (left) and lateral (right) views of the glans penis of Cerradomys vivoi from Jequitinhonha, Minas Gerais (UFMG 1458). Bony baculum length: $8.5 \mathrm{~mm}$.

the existence of new species of this genus has been informally mentioned in literature. This was the case of Cerradomys sp.n.2 (= Oryzomys sp.n.2; Bonvicino and Moreira, 2001), which is the same taxon denominated Oryzomys subflavus variant 3 (Bonvicino et al., 1999) and Oryzomys subflavus 2 (Bonvicino, 2003: 82, table 1). And similarly, of Cerradomys sp.n.1 (= Oryzomys sp.n.1; Bonvicino and Moreira, 2001), a synonym of Oryzomys subflavus variant 1 (Bonvicino et al., 1999) and Oryzomys subflavus 3 (Bonvicino, 2003: 82, table 1).

We compared the voucher specimens of Bonvicino et al. (1999), Langguth and Bonvicino (2002), and Bonvicino (2003) to other museum samples. Samples from northeastern Brazil, from the left bank of Rio Sao Francisco, in the states of Pernambuco and Paraíba, Ceará, and Maranhão are herein assigned as a new species, Cerradomys langguthi n. sp., based on the morphological congruence between the specimen karyotyped by Bonvicino and Moreira (2001; Oryzomys sp.n.1; MN 69786, field number AL 3655) and other examined specimens. Specimens from Sergipe, Bahia, and northern Minas Gerais, from the right bank of Rio Sao Francisco, share several morphologic similarities with specimen LV-FC 148 (named Oryzomys sp.n.2) analyzed by Bonvicino and Moreira (2001) and with the new species herein described, Cerradomys vivoi n. sp.

\section{Cerradomys langguthi, new species}

Figures 1, 3, 5, 8; tables 1 and 2

Holotype: MN 69786, an adult specimen of unknown sex collected by Alfredo Langguth (original field number AL3655), on December 2, 1995. The holotype consists of a skull with an incomplete right zygomatic arch and a partial postcranial skeleton. ${ }^{1} \mathrm{~A}$ bone marrow suspension of cells in Carnoy's fixative (methanol:acetic acid) and a liver tissue sample preserved in ethanol are housed at Laboratório de Biologia e Parasitologia de Mamíferos Reservatórios Silvestres, Instituto Osvaldo Cruz-FIOCRUZ, under the original field number AL 3655. Cytochrome $b$ DNA data were deposited in GenBank with the accession number AF181276.

Selected skull dimensions of holotype are: CIL, 32.1; LD, 9.6; LM, 4.95; BM1, 1.45; LIF, 7.15; PB, 5.7; BR, 5.65; LN, 13.55; LPB, 5.2; HB, 10.4; LIB, 5.35; CZL, 24.3; OL, 11.8.

PARATYPES: All specimens listed under "Specimens Examined" are herein assigned as paratypes of Cerradomys langguthi.

Type Locality: The holotype of Cerradomys langguthi was collected at Corredor São João-Fazenda Pacatuba, Sapé, State of Paraíba, Brazil, at ca. $07^{\circ} 02^{\prime} \mathrm{S}, 35^{\circ} 09^{\prime} \mathrm{W}$. Fazenda São João and Fazenda Pacatuba are Atlantic Forest remnants, which are connected by a corridor of native vegetation.

Distribution: The known collection localities of $C$. langguthi are distributed on the left bank of Rio São Francisco, throughout the Brazilian states of Pernambuco, Paraíba, Ceará, and Maranhão. In Pernambuco, Paraíba, and Ceará, distributional records extend from coastal lowlands to inland highlands and mountain ranges. Collection records in Maranhão are associated with lowlands of the central portion of the state (fig. 1).

\footnotetext{
${ }^{1}$ Although the specimen MN 69786 is lacking its skin, it was selected as the holotype, because it is the only available specimen with skull, karyotype, and tissue sample, together the most informative traits for recognition of this species.
} 


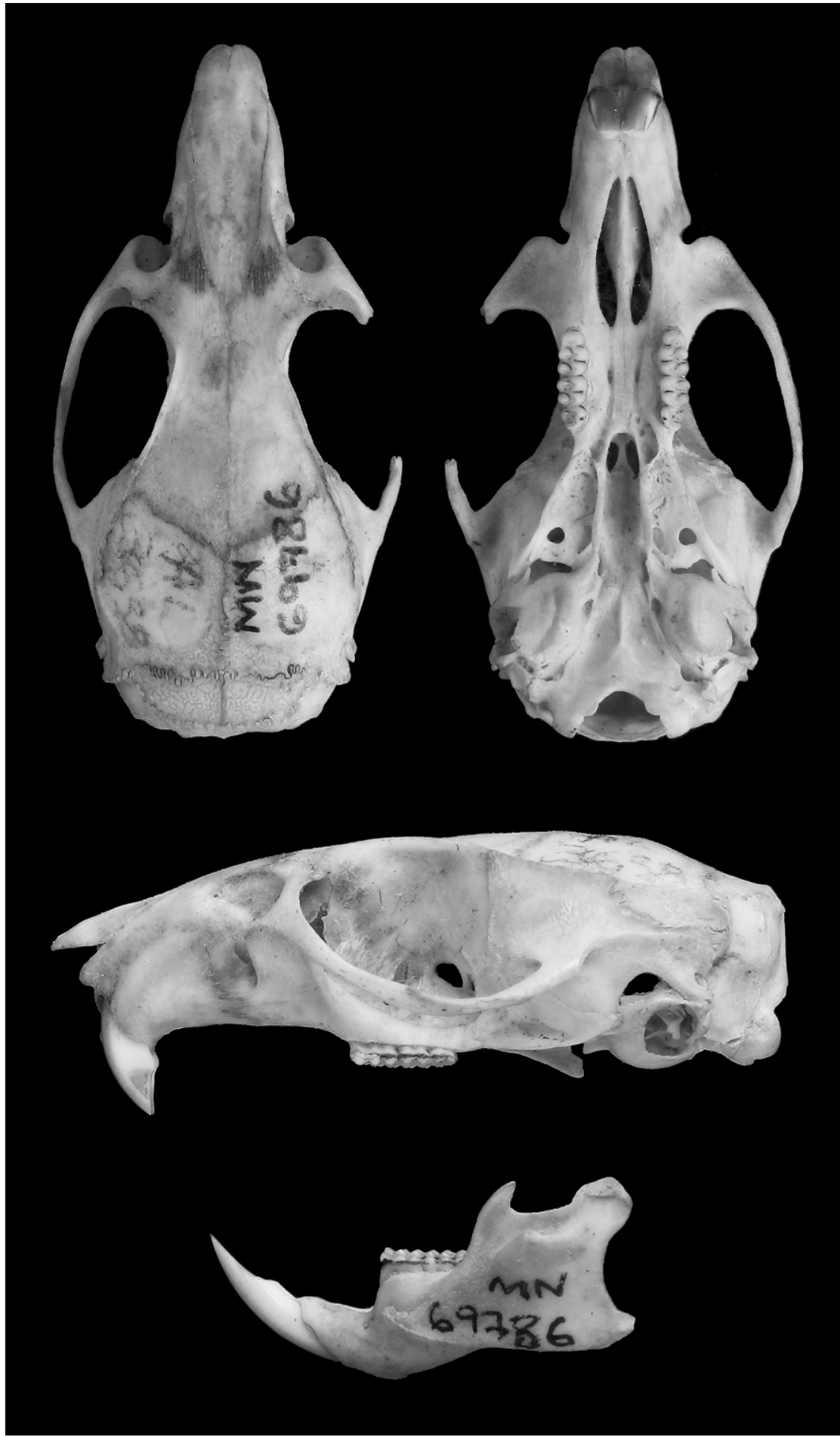

Fig. 8. Dorsal, ventral, and lateral cranial views of holotype of Cerradomys langguthi (MN 69786; CIL, $32.1 \mathrm{~mm})$. 


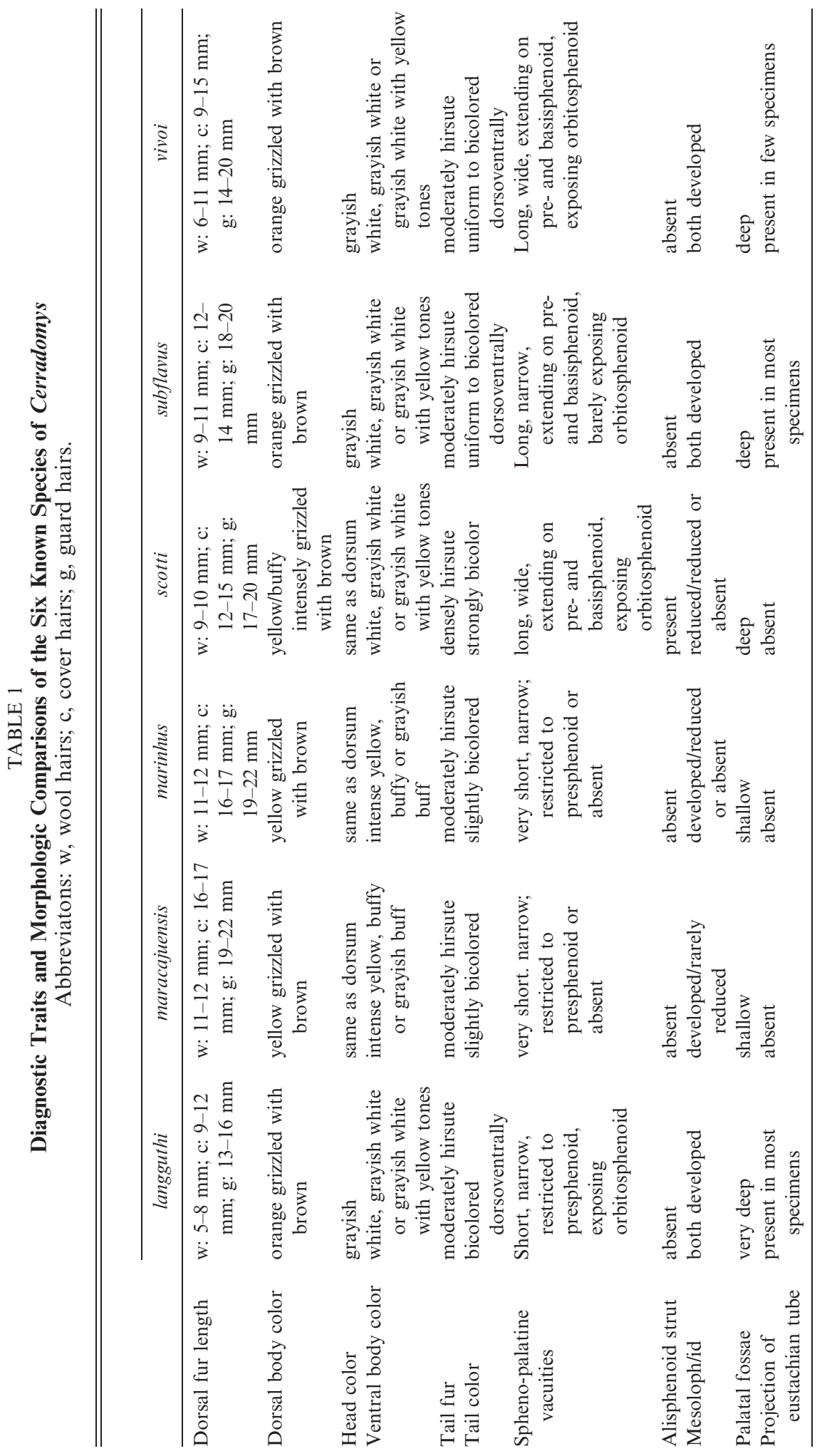


TABLE 2

Descriptive Statistics of External and Skull Measurements for the Three Species of Cerradomys from Eastern Brazil

Mean \pm standard deviation, (minimum-maximum), $\mathrm{N}$.

\begin{tabular}{lccc}
\hline \hline & C. subflavus & C. vivoi & C. langguthi \\
\hline HBL & $151.38 \pm 11.46(125-179) 52$ & $143.31 \pm 8.65(127-160) 36$ & $136.30 \pm 7.76(119-153) 73$ \\
LT & $179.87 \pm 13.44(150-210) 47$ & $177.36 \pm 11.48(153-200) 39$ & $169.61 \pm 10.93(144-195) 69$ \\
HF & $34.02 \pm 2.07(30-38) 51$ & $33.12 \pm 1.53(30-36) 39$ & $32.58 \pm 1.35(30-35) 77$ \\
Ear & $21.35 \pm 2.04(17-25) 52$ & $21.94 \pm 1.70(18-25) 40$ & $20.54 \pm 0.90(19-22) 59$ \\
Wt & $96.44 \pm 16.97(69-129) 27$ & $77.56 \pm 12.49(54.50-110) 38$ & $62.57 \pm 10.86(37.5-85) 70$ \\
CIL & $34.36 \pm 1.40(30.67-36.52) 52$ & $32.93 \pm 1.13(30.76-35.41) 43$ & $31.51 \pm 1.00(29.23-33.45) 65$ \\
LD & $10.32 \pm 0.68(8.79-11.77) 56$ & $10.07 \pm 0.58(8.89-11.24) 42$ & $9.40 \pm 0.45(8.32-10.45) 65$ \\
LM & $5.17 \pm 0.18(4.77-5.52) 56$ & $4.91 \pm 0.17(4.58-5.29) 40$ & $4.90 \pm 0.15(4.52-5.19) 59$ \\
BM1 & $1.49 \pm 0.06(1.35-1.62) 60$ & $1.41 \pm 0.07(1.26-1.58) 43$ & $1.42 \pm 0.06(1.28-1.55) 77$ \\
LIF & $7.69 \pm 0.48(6.53-8.63) 60$ & $7.51 \pm 0.37(6.82-8.38) 43$ & $6.97 \pm 0.30(6.28-7.5) 79$ \\
PB & $6.13 \pm 0.24(5.56-6.77) 59$ & $5.71 \pm 0.26(5.17-6.23) 43$ & $5.71 \pm 0.22(5.18-6.14) 79$ \\
BR & $9.65 \pm 0.56(8.51-10.84) 53$ & $9.34 \pm 0.59(7.89-10.61) 41$ & $9.66 \pm 0.47(8.57-10.78) 69$ \\
LN & $14.17 \pm 0.86(11.98-16.00) 60$ & $13.73 \pm 0.66(12.30-15.01) 41$ & $13.54 \pm 0.57(12.22-14.97) 72$ \\
LPB & $5.94 \pm 0.22(5.39-6.50) 57$ & $5.89 \pm 0.28(5.37-6.60) 42$ & $5.62 \pm 0.31(4.91-6.31) 79$ \\
HB & $11.04 \pm 0.37(10.39-11.97) 54$ & $10.73 \pm 0.42(9.78-11.69) 40$ & $10.32 \pm 0.37(9.58-11.13) 62$ \\
LIB & $6.33 \pm 0.33(5.73-7.06) 60$ & $5.83 \pm 0.26(5.19-6.39) 41$ & $5.67 \pm 0.30(5.14-6.4) 79$ \\
ZB & $18.97 \pm 0.72(17.27-20.56) 47$ & $17.89 \pm 0.62(16.63-19.09) 40$ & $17.52 \pm 0.66(16.17-19.2) 66$ \\
CZL & $26.39 \pm 1.01(24.04-28.31) 52$ & $25.20 \pm 0.82(23.72-26.98) 43$ & $24.15 \pm 0.87(21.92-26.5) 69$ \\
OFL & $13.08 \pm 0.56(11.56-14.01) 60$ & $12.38 \pm 0.45(11.43-13.46) 42$ & $11.81 \pm 0.41(10.81-12.83) 78$ \\
BB & $5.34 \pm 0.15(5.04-5.71) 54$ & $5.03 \pm 0.18(4.64-5.39) 41$ & $4.85 \pm 0.22(4.34-5.34) 68$ \\
\hline
\end{tabular}

ETyMology: This species is named after Dr. Alfredo Ricardo Langguth Bonino for his long-term dedication and commitment to the development of Brazilian mammalogy.

Diagnosis: Cerradomys langguthi is characterized by small body size, short and dense dorsal pelage, dorsal body color orange grizzled with brown, head color grayish, ventral body color grayish or slightly yellowish, short and narrow sphenopalatine vacuities, restricted to presphenoid, exposing partially orbitosphenoid, alisphenoid strut absent, deep palatal fossae (complex posterolateral palatal pits), and a unique chromosomal formula $(2 \mathrm{n}=48-50, \mathrm{FN}=56)$.

Morphological Description: Head and body size small (table 2); tail length longer than head and body $(102 \%-144 \%$ of head and body length); hindfeet moderately narrow and long ( $21 \%-24 \%$ of head and body length), with large and fleshy interdigital, thenar, and hypothenar pads; pinnae rounded and small $(11.3 \%-17 \%$ of head and body length). Dorsal pelage short and dense (table 1), consisting of short, dense underfur (wool hairs; thin, wavy, short) and longer and lax overfur (cover and guard hairs; thick, long). Dorsal body color buffy orange densely grizzled with black; wool hairs (range: 5-8 $\mathrm{mm}$ ) with basal part grayish and distal part (1/10 of total length) orange or brown; cover hairs long (range: 9-12 mm), with distal 1/4 dark brown with a subterminal orange band; guard hairs sparse and long (range: 13-16 mm), with distal half entirely black or dark brown. Anterior half of head (until eyes) covered with gray-based and white- or buffy-tipped hairs, clearly distinct from color of posterior half of head and dorsal body fur. Ventral pelage composed of wool underfur and cover and guard hairs, with individual hairs grayish-based and tipped with white, buffy or yellowish; general ventral color grayish, buffy, or yellowish, slightly grizzled, and distinctively lighter than dorsal pelage. Flanks bright orange; banded cover hairs and dark guard hairs rare. Mystacial vibrissae long, reaching but not surpassing pinnae when laid back. Tail slightly bicolored to bicolored, covered with short, sparse brown hairs and scales on dorsal surface and unpigmented hairs and scales on ventral surface. Dorsal surface of hind foot white, covered with short, entirely white hairs (only young individuals present hairs with $3 / 4$ distal portion white and 
basal 1/4 grayish or washed brown); ungual tufts sparse, shorter than claws especially on digit I; ventral surface naked, unpigmented, with four interdigital pads and two tarsal pads (thenar and hypothenar). Pinnae covered internally with short orange hairs and externally with orange, brown-tipped hairs.

Skull size small (tables 1, 2; figs. 3, 5, 8). Rostrum long and broad, tapering, with inflated capsular projection of nasolacrimal foramen, and flanked by deeply excavated zygomatic notches; interobital region long and narrow (table 2), converging anteriorly, with dorsolateral margins with sharp and welldeveloped supraorbital crests; braincase oblong, with prominent temporal crests. Zygomatic plate (in lateral view) projected forward, with dorsal free margin rounded and anterior margin straight or slightly concave, and zygomatic spine absent. Incisive foramina long (averaging about $74.4 \%$ of length of diastema), with lateral margins concave and diverging posteriorly, and wider posteriorly; posterior margins extending or not between the alveolus of upper first molars. Palate long and wide (sensu Hershkovitz, 1962); posterolateral palatal pits numerous and complex, recessed in very deep palatal fossae; palatal excrescences rarely present. Mesopterygoid fossa narrow, with anterior margin rounded or slightly acute, not reaching the alveolus of M3; bony roof of mesopterygoid fossa perforated by short, narrow to wide sphenopalatine vacuities, restricted to presphenoid, partially or totally exposing the orbitosphenoid. Alisphenoid strut absent (buccinator-masticatory foramen and ovale foramen confluent). Postglenoid foramen large and nearly semicircular in shape separated from small or absent subsquamosal fenestra (small in 62.5\% and absent in $37.5 \%$ of 16 specimens examined for this trait), by a wide hamular process of squamosal. Tegmen tympani weakly overlapping squamosal; posterior suspensory process of squamosal absent. Ectotympanic bullae globose; eustachian tube short, with distinct medial laminae in a few specimens; stapedial process short and wide, overlapping squamosal; bony process dorsal to stapedial process present, overlapping squamosal.

Mandible long and deep (figs. 5, 8); coronoid process large, falciform or triangular, nearly equal to condyloid process; superior notch shallow; angular process short, not surpassing the condyloid process posteriorly; inferior notch shallow; capsular process of lower incisor well developed.

Incisors, upper and lower molars as for the genus (no mesoloph/mesolophid reduction was observed in $C$. langguthi). Mammary counts and soft anatomy (stomach and glans penis) as described for the genus.

KaRYology: The Cerradomys langguthi holotype shows a karyotype with $2 \mathrm{n}=50$ and $\mathrm{FN}=56$ (table 7). The autosomal complement of specimens with $2 \mathrm{n}=50$ comprises four biarmed pairs (1 large, 3 medium to small pairs) and 20 acrocentric pairs (3 large and 17 medium to small pairs). The $\mathrm{X}$ chromosome is a medium-sized acrocentric and the $\mathrm{Y}$ chromosome a small-sized acrocentric. Variation in diploid number is due to centric fusion affecting two acrocentric pairs.

Maia and Hulak (1981) reported a variation on the chromosomal diploid number in Pernambuco samples (Tupanatinga, Buíque, Bom Conselho, Capoeiras, Correntes, Panelas, Caruaru, São Lourenço, and Exu), with $2 \mathrm{n}=$ 48, 49, and 50; all karyotypes present the same fundamental number $\mathrm{FN}=56$. The karyotype of the holotype is coincident with the $2 \mathrm{n}=50$, $\mathrm{FN}=56$ karyotype presented by Maia and Hulak (1981). Moreover, when examining specimens from Buique, one of the localities sampled by Maia and Hulak (1981), we found them to be conspecific with $C$. langguthi.

The $2 \mathrm{n}=48-49-50$ polymorphism reported by Maia and Hulak (1981) results from multiple centric fusions. The karyotype observed in the Exu sample, $2 \mathrm{n}=46, \mathrm{FN}=56$, differs from the basic complement by the presence of two large submetacentric pairs formed by centric fusions. Bonvicino (2003) recognizes this karyotype as a distinct karyomorph, altough we do not have compelling morphologic or molecular evidence to consider it a separate form.

Natural History: Cerradomys langguthi inhabits several vegetation types: the coastal lowland humid Atlantic Forest (locally called "Zona da Mata"); the open and relatively dry forests (locally called as "Agreste") in the zone between the more humid and dense coastal forest and the more open and drier Caatinga; 
the arbustive and arboreal Caatinga; and the forests restricted to humid slopes of mountain ranges in areas of Caatinga ("Brejos").

Paiva (1973) associated this species with sugar-cane plantations, near humid and mesic areas, in Ceará. This habitat is also pointed by Mares et al. (1981) and Streilein (1982) as typical for $C$. langguthi in Pernambuco. Karimi et al. (1976) also obtained this species in natural and cultivated fields, reporting nests in more humid grass patches. We trapped specimens of $C$. langguthi at secondary forests and shade coffee plantations on the slopes of Serra de Baturité (a typical "Brejo") in Ceará.

Specimens Examined: BRAZIL: Ceará: Pacoti (Sítio Friburgo), Serra de Baturité: M: MZUSP ARP 11, 45, 77. Crato (Guaribas, Sítio Páscoa): UFMG YL 264, 289. Maranhão: Alto Parnahyba $(=$ Alto Parnaíba): F: FMNH 26446. Fazenda Lagoa Nova, Bacabal: F: MPEG 23482. Paraíba: Corredor São João-Fazenda Pacatuba, Sapé: I: MN 69786 (holotype of C. langguthi). João Pessoa: M: UFPB 31, 92, 386; F: UFPB 2081; I: UFPB 2079. Mamanguape, Fazenda Alagamar, Mamanguape: M: UFPB 2061. Areias, Mata de Pau Ferro, Areias: M: UFPB 2065. Natuba: M: UFPB 24, 38, 41, 63, 175, 258, 2066, 2073, 2078; F: UFPB 25, 31, 35, 257, 2068. Pirauá, Natuba: M: UFPB 1, 178, 180, 181, 182, 183, 221, 2059; F: UFPB 12, 220; I: UFPB 47. Salgado São Félix: M: UFPB: M 28, 37, 39, 45, 46, 228, 231, 2057; F: UFPB 29, 37, 233; I: UFPB 229. Teixeira, Pico do Jabre: M: UFPB 1955, 1977, 2367; F: UFPB 1976, 2060, 2366. Pernambuco: Exu: M: MZUSP 18900-1, 18906, 18908, 18910; F: MZUSP 18904, 18909; I: MZUSP 18903. Fazenda Saco, Exu: M: MZUSP 18905. Macaparana: UFPB 14, 33, 224, 269, 271, 272, 2056, 2070; F: UFPB 15, 21; I: UFPB 148. São Vicente Ferrer: M: UFPB 19, 150, 151, 267, 2072; F: UFPB 18, 38, 155, 156. Sítio Mata Verde, Buíque: M: MZUSP 20604. Piauí: Arara: M: FMNH 25246; F: FMNH 25247.

\section{Cerradomys maracajuensis (Langguth and Bonvicino, 2002)}

Oryzomys maracajuensis Langguth and Bonvicino, 2002: 292; type locality: "Brazil, Mato Grosso do Sul:
Municipality of Maracaju (approx. $21^{\circ} 38^{\prime} \mathrm{S}, 55^{\circ} 09^{\prime} \mathrm{W}$ ) Fazenda da Mata".

[Cerradomys] maracajuensis: Weksler et al., 2006: 8.

Type Locality: "Brazil, Mato Grosso do Sul: Municipality of Maracaju (approx. $\left.21^{\circ} 38^{\prime} \mathrm{S}, 55^{\circ} 09^{\prime} \mathrm{W}\right)$ Fazenda da Mata”.

Geographic Distribution: The known collection localities of $C$. maracajuensis (figs. 1, 2) are distributed across the Brazilian Cerrado on Minas Gerais, Mato Grosso do Sul, and Mato Grosso to Paraguayan open areas of Amambay, Caaguazu, Canendiyu, Paraguari, La Cordillera, San Pedro, and Concepcion. To west, C. maracajuensis penetrates the open vegetation lowlands of Bolivia, at Beni, Santa Cruz, and La Paz, and Peru, at Puno. Most records are from lowlands although there are also records of specimens from highlands and dissected highlands of central South America; the known altitudinal range varyies from $102 \mathrm{~m}$ (Tacuati, Paraguay; USNM 293154) to 1750 m (Pitiguaya, Bolívia; e.g., AMNH 72641).

Diagnosis: C. maracajuensis is characterized by large body and tail size (HBL range: $140-185 \mathrm{~mm}$; TL range: $171-227 \mathrm{~mm}$; see table 3 ), long and more robust feet (HF range: $34-43 \mathrm{~mm}$ ), dorsal body color coarsely grizzled, buffy brown to orange brown, ventral body color grayish to buffy to yellow gray, skull (figs. 4, 6) with shallow rostral fossa, mesopterygoid fossa with small and narrow sphenopalatine vacuities or fully ossified, shallow palatal fossae (simple and large posterolateral palatal pits), developed palatal excrescences, mesolophid developed (narrow and reduced in few individuals from Bolivia), central cartilaginous digit of distal baculum absent, and a unique chromosomal formula $(2 \mathrm{n}=56, \mathrm{FN}=58)$.

KARYOLOGY: Diploid number of 56 chromosomes and low fundamental number of 58 autosomes are diagnostic for this species when compared with other congeneric species (see Bonvicino et al., 1999; Langguth and Bonvicino, 2002: fig. 3).

Natural History: Available data on museum specimens relating to the natural history of $C$. maracajuensis report habitat preference: Near the type locality, Maracaju, specimens were collected in some distinct habitats like "woods", "bush and grass", "Brush pile in 
TABLE 3

Descriptive Statistics of External and Skull Measurements for the Three Species of Cerradomys Mean \pm standard deviation, (minimum-maximum), N.

\begin{tabular}{lccc}
\hline \hline & C. maracajuensis & C. marinhus & C. scotti \\
\hline HBL & $151.48 \pm 13.17(123-185) 88$ & $168.00 \pm 11.07(153-179) 5$ & $148.23 \pm 13.02(125-181) 60$ \\
LT & $181.26 \pm 13.72(157-215) 87$ & $203.58 \pm 6.25(198-212) 6$ & $164.98 \pm 12.71(141-198) 55$ \\
HF & $35.16 \pm 2.30(30-40) 84$ & $40.33 \pm 1.75(38-43) 6$ & $31.65 \pm 2.11(27-37) 56$ \\
Ear & $20.49 \pm 0.97(19-22) 70$ & $22.58 \pm 1.07(21.50-24) 6$ & $22.18 \pm 1.92(18-26) 58$ \\
Wt & $91.10 \pm 16.78(54-125) 46$ & $130 \pm 18.03(105-150) 5$ & $91.95 \pm 18.10(55-133) 45$ \\
CIL & $32.60 \pm 1.14(29.68-35.39) 80$ & $36.05 \pm 1.38(34.32-38.25) 6$ & $33.08 \pm 1.41(30.27-36.07) 63$ \\
LD & $9.50 \pm 0.49(8.50-10.82) 93$ & $10.38 \pm 0.20(10.18-10.63) 4$ & $9.66 \pm 0.60(8.59-10.95) 61$ \\
LM & $5.26 \pm 0.19(4.79-5.67) 95$ & $5.74 \pm 0.11(5.58-5.86) 6$ & $5.05 \pm 0.16(4.71-5.39) 61$ \\
BM1 & $1.54 \pm 0.08(1.37-1.74) 96$ & $1.72 \pm 0.04(1.66-1.77) 6$ & $1.52 \pm 0.04(1.44-1.60) 54$ \\
LIF & $7.07 \pm 0.40(6.10-7.96) 95$ & $7.47 \pm 0.40(7.09-8.15) 6$ & $6.83 \pm 0.32(6.14-7.55) 65$ \\
PB & $6.22 \pm 0.26(5.60-6.80) 94$ & $6.41 \pm 0.12(6.25-6.57) 5$ & $6.22 \pm 0.31(5.55-6.92) 65$ \\
BR & $9.80 \pm 0.75(7.65-11.48) 92$ & $9.92 \pm 0.50(9.62-10.67) 4$ & $9.89 \pm 0.66(8.55-11.49) 54$ \\
LN & $14.02 \pm 0.74(12.3015 .88) 92$ & $16.16 \pm 0.59(15.14-16.70) 6$ & $14.54 \pm 0.99(12.08-16.93) 64$ \\
LPB & $6.37 \pm 0.39(5.62-7.32) 96$ & $7.53 \pm 0.59(6.84-8.46) 6$ & $6.45 \pm 0.42(5.66-7.39) 64$ \\
HB & $11.06 \pm 0.34(10.26-11.82) 87$ & $11.74 \pm 0.33(11.22-11.99) 6$ & $11.24 \pm 0.46(10.34-12.26) 60$ \\
LIB & $5.92 \pm 0.42(5.14-6.84) 90$ & $7.08 \pm 0.34(6.73-7.56) 6$ & $5.83 \pm 0.40(4.89-6.72) 64$ \\
ZB & $18.88 \pm 0.74(17.12-20.69) 84$ & $19.85 \pm 0.77(18.79-20.66) 6$ & $18.82 \pm 0.90(17.12-20.89) 57$ \\
CZL & $25.63 \pm 0.99(23.29-27.72) 84$ & $27.47 \pm 0.52(26.71-28.01) 5$ & $25.76 \pm 1.11(23.46-27.91) 63$ \\
OFL & $12.80 \pm 0.40(11.93-13.64) 90$ & $13.58 \pm 0.45(13.09-14.20) 6$ & $13.32 \pm 0.53(12.32-14.44) 64$ \\
BB & $5.26 \pm 0.19(4.85-5.73) 92$ & $5.42 \pm 0.08(5.34-5.55) 6$ & $5.35 \pm 0.21(4.79-5.70) 61$ \\
\hline
\end{tabular}

grass at edge of rice field", "Brush-Swampy", "Forest", and "Brush and grass" (R.M. Gilmore, in museum tags at AMNH and $\mathrm{MN}$ ), but also in gallery forest (Langguth and Bonvicino, 2002). In Bolivia, specimens were collected in dense shrub-grass field (cleared forest), dense forest adjacent (G. Schmitt, AMNH tags). Pregnant females were observed in Bolivia during June and September, with two and four embryos (Anderson, 1997).

SPecimens Examined: BOLIVIA: Beni: Boca del Rio Baures: M: AMNH 210227; F: AMNH 210025. Camino Vilches: F: FMNH 116820. Centenela, Rio Machupo, E San Joaquin: M: FMNH 116835-7, 116839, 1168412, 116844, 116846; F: FMNH 116833-4, 116838, 116840, 116845. Pampa de Meio: F: AMNH 210024. Puerto Almacen: M: AMNH 255956, 255979. Rio Beni, Magdalena: M: FMNH 116823; F: FMNH 116908. Rio Itenez, opposite Costa Marques: M: AMNH 210026-7. Rio Mamore, circa $10 \mathrm{~km}$ W San Pedro: M: AMNH 211801; F: AMNH 211802. Rio Mamore, en la boa del Rio Ibare: M: AMNH 211793. Rio Mamore, Puerto Caballo: M: AMNH 211794, 211799; F: AMNH 211795-8. Rio Mamore, W San Javier: M: AMNH 211800. San Joaquin:
M: FMNH 96103, 116762, 116773, 116775-8, $116810,116812,116819,116848-9,116852$, 116855-6, 116858-9, 116880, USNM 364746, 390673; F: FMNH 96109, 116754-6, 116760-1, 116763, 116767, 116788, 116790, 116832, 116854, 116866, 116875, 116902, 116910. LA PAz: La Florida (= Pitiguaya): M: AMNH 72641, 72717; F: AMNH 72642-3, 72719, 72780. Rio Beni: F: AMNH 262077. SANTA Cruz: $1 \mathrm{~km}$ NE Estancia Las Cuevas: F: AMNH 264196. $3 \mathrm{~km}$ SE Montero: F: AMNH 264194. $3.5 \mathrm{~km} \mathrm{~W}$ W Estacion Pailon: F: AMNH 260383-4. 6 km N Buen Retiro: F: AMNH 260378-9. $6 \mathrm{~km}$ W Ascencion: F: AMNH 262076. $7 \mathrm{~km} \mathrm{~N}$ and $17 \mathrm{~km} \mathrm{~W}$ Buena Vista: F: AMNH 246934. $12 \mathrm{~km} \mathrm{~S}$ and $8 \mathrm{~km} \mathrm{E}$ Santa Cruz: F: AMNH 255954. 15 km S Santa Cruz: F: AMNH 264195. Ayacucho: M: AMNH 263342; F: AMNH 263343, USNM 391395. Buena Vista: M: BMNH 26.12.4.42-43, FMNH 51911; F: BMNH: 28.2.9.33. Cordillera, Basilio: F: USNM 390678. El Refugio Pampa, NE from camp: M: USNM 584576, 584580; F: USNM IGP 43-4, 50-1, 584578-9. Estancia Cachuela Esperanza: M: AMNH 260380-1. Rio Palomitillas, Buena Vista: M: BMNH 28.2.9.36-37. San Miguel Rincon: M: AMNH 
260385, 260388; F: AMNH 260386-7. San Rafael de Amboro: M: AMNH 262073. Warnes: USNM: F: USNM 390675-6. BRAZIL: Mato Grosso: $264 \mathrm{~km} \quad \mathrm{~N}$ Xavantina, Serra do Roncador: M: BMNH 81.450; F: BMNH 81.449. Mato Grosso do Sul: Fazenda da Mata, Maracaju: M: MN 44178 (holotype of C. maracajuensis). Fazenda Primavera, Bataiporã: M: MZUSP 28766. Maracaju: M: AMNH 134518, 134705, 134710, MN 4409, 4376; F: AMNH 134708, 134711-2, MN 4410; I: AMNH 134832, 134854. Minas Gerais: Reserva do Jacob, Nova Ponte: UFMG 1970. PARAGUAY: Amambay: $28 \mathrm{~km}$ SW Pedro Juan Caballero: F: UMMZ 125228. Parque Nacional Cerro Corá: M: USNM 554541; F: USNM 554542-3. Caaguazu: $24 \mathrm{~km}$ NNW Carayao: F: UMMZ 133797. Canendiyu: $13.3 \mathrm{~km}$ N Curuguaty: M: UMMZ 133799-800; F: UMMZ 133798. Villa Igatimi: MLP C 02589. PARAguarI: Sapucay: M: BMNH 3.2.3.5, 3.4.7.14, 4.1.5.13, 4.1.5.14, 4.1.5.15; F: BMNH 3.4.7.15, 3.2.3.9, 4.1.5.16; I: BMNH 3.2.3.6. Tacuati, Aca Poi: M: USNM 293154. SAN Pedro: Ganadera La Carolina: F: GD 371-32. PERU: Puno: Rio Heath, Aguas Claras Camp: M: USNM 579688.

\section{Cerradomys marinhus (Bonvicino, 2003)}

Oryzomys marinhus Bonvicino, 2003: 84; type locality: "Fazenda Sertão do Formoso (known before as Fazenda Jucurutu, $14^{\circ} 40^{\prime} 20^{\prime \prime} \mathrm{S} 45^{\circ} 49^{\prime} 71^{\prime \prime}$ [sic]W, altitude around $775 \mathrm{~m}$ ), Jaborandi municipality, state of Goiás, Brazil".

[Cerradomys] marinhus: Weksler et al., 2006: 8.

Type Locality: "Fazenda Sertão do Formoso (known before as Fazenda Jucurutu, $14^{\circ} 40^{\prime} 20^{\prime \prime} \mathrm{S} 45^{\circ} 49^{\prime} 71^{\prime \prime}[\mathrm{sic}] \mathrm{W}$, altitude around $775 \mathrm{~m}$ ), Jaborandi municipality, state of Goiás, Brazil". However, Bonvicino (2003: 79) previously reported that Fazenda Sertão do Formoso was "located in Jaborandi and Cocos municipalities, Bahia state" (see also IBGE, 1972, for the location of these municipalities). Moreover, the geographical coordinates originally presented by Bonvicino did not refer to the collecting locality of the type series. More precisely, all these specimens were captured in

\footnotetext{
${ }^{2}$ These specimens were employed by D'Elía et al. (submitted) as vouchers for the first record of $C$. maracajuensis for Paraguay.
}

one specific habitat type, "veredas", whose geographical coordinates were also furnished by the author (Bonvicino, 2003: 79). Thus, the correct type locality for this species is herein corrected and restricted to: Fazenda Sertão do Formoso, (formerly known as Fazenda Jucurutu, $14^{\circ} 48^{\prime} \mathrm{S}, 45^{\circ} 57^{\prime} \mathrm{W}$, altitude around $775 \mathrm{~m}$ ), Jaborandi municipality, state of Bahia, Brazil.

Geographic Distribution: Besides the type locality, $C$. marinhus is known from one collection locality in northwestern Minas Gerais state (figs. 1, 2).

Diagnosis: C. marinhus is characterized by large body and tail size (HBL range, 153$179 \mathrm{~mm}$; TL range, $198-212 \mathrm{~mm}$; table 3), long and robust feet (HF range, 38-43 mm), dorsal body color coarsely grizzled, buffy brown to orange brown, ventral body color grayish to buffy to yellowish gray, skull with shallow rostral fossa (figs. 4, 6), mesopterygoid fossa with small and narrow sphenopalatine vacuities or fully ossified, shallow palatal fossae (simple and large posterolateral palatal pits), m3 with reduced or absent mesolophid, and a unique chromosomal formula $(2 \mathrm{n}=56$, $\mathrm{FN}=54)$.

KARYOLOGY: The karyotype of $C$. marinhus presents $2 \mathrm{n}=56$ and $\mathrm{FN}=54$; the autosomal complement comprises 27 acrocentric pairs, from large to small. Sexual chromosomes differ in size, with the $\mathrm{X}$ chromosome being a large acrocentric and the $\mathrm{Y}$ a small-size acrocentric (Bonvicino et al., 1999; Bonvicino, 2003).

Natural History: Specimens of $O$. marinhus from Fazenda Sertão do Formoso were captured in a particular Cerrado habitat, called "vereda". "Vereda" is a periodically flooded grassland habitat with scattered palm species of genera Mauritia and Mauritiella, generally in Cerrado stream headwaters (see detailed decription in Bonvicino, 2003: 79, 87). Specimens from Parque Nacional Grande Sertão Veredas were captured at seasonally flooded semideciduous forests (A.P. Carmignotto field notes).

Reproductive data suggested that females breed throughout the year because pregnant females were captured both in dry and rainy seasons, with embryo numbers ranging from $2-4$, and with a modal number of 4 embryos 
(Bonvicino, 2003: 87). Cerradomys marinhus is infested by ectopasites like mites and ticks of the order Mesostigmata (family Ixodidae); fleas Polygenis [Polygenis] tripus; and flies of the family Hippoboscidae (Bonvicino, 2003: 88).

Specimens Examined: BRAZIL: Bahia: Fazenda Sertão do Formoso, Jaborandi: M: MN 63822-3, 63830 (holotype of C. marinhus), 63834; F: MN 63831, 63837. Minas Gerais: Parque Nacional Grande Sertão Veredas: M: MZUSP APC 764; F: MZUSP APC 742.

\section{Cerradomys scotti}

(Langguth and Bonvicino, 2003)

Oryzomys scotti Langguth and Bonvicino, 2003: 290; type locality: "Brazil, Goiás: municipality of Corumbá de Goiás

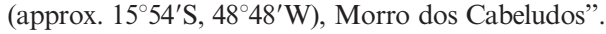

Oryzomys andersoni Brooks, Baker, Vargas, Tarifa, Aranibar and Rojas, 2004: 3; type locality: "Pozo Mario, Estancia Las Conchas, Santa Cruz, Bolivia; $1735^{\prime} 46.9^{\prime \prime}$ S; $5930^{\prime} 20.5^{\prime \prime} \mathrm{W}^{\prime \prime}$

[Cerradomys] scotti: Weksler et al., 2006: 8.

Type Locality: "Brazil, Goiás: municipality of Corumbá de Goiás (approx. $\left.15^{\circ} 54^{\prime} \mathrm{S}, 48^{\circ} 48^{\prime} \mathrm{W}\right)$, Morro dos Cabeludos".

Geographic Distribution: Cerradomys scotti presents a large distribution area in central South America (figs. 1, 2), with limits similar to those of the biome Cerrado. Collecting records were found along a northsouth transect, from the Brazilian states of Piauí, Maranhão, and Tocantins to the southcentral state of Paraguari in Paraguay. Similarly, collecting records of $C$. scotti were found across an east-west transect, from the eastern Brazilian state of Minas Gerais to the eastern Departamento de Santa Cruz in Bolivia.

This species is geographically restricted to the central Brazilian highlands and several adjacent areas. Altitudinally, $C$. scotti is distributed from $250 \mathrm{~m}$ in Santa Rosa de la Roca, Santa Cruz, Bolivia, to $1180 \mathrm{~m}$ in Alto Paraíso, Goiás, Brazil.

TAXonomic Comments: Based on molecular evidence, Emmons et al. (2006) suggest that Cerradomys andersoni is conspecific with, and consequently a junior synonym of $C$. scotti. Brooks et al. (2004) also highlighted the close relationship of cytocrome $b$ haplotype of C. andersoni holotype (CBF 6151) and the specimen deposited in GenBank under the accession number AF181277 (voucher specimens: MN50379, MN61677), herein identified as C. scotti.

The only known specimen of $C$. andersoni shared similarities with specimens of $C$. scotti (based on photographs of the holotype provided by Dr. Julieta Vargas): bicolored tail, presence of alisphenoid strut, and reduction of mesoloph on M2. Additionally, it was nearly identical with the C. scotti holotype, with some other Bolivian specimens from Santa Cruz (AMNH 263872), and with some Paraguayan specimens from Sapucay (USNM 121389-91, 121393-5), Tobati (UMMZ 126005, MVZ 145148), Altos (MVZ 145147), and Concepcion (MVZ 141890).

The karyotype of $C$. andersoni is unknown, precluding comparisons with our samples of C. scotti. However, our data support the taxonomic decision held by Emmons et al. (2006), and we also consider $C$. andersoni a junior synonym to $C$. scotti.

Diagnosis: $C$. scotti is characterized by medium body and tail size (HBL range, 125$181 \mathrm{~mm}$; TL range, $141-198 \mathrm{~mm}$; table 3), small feet (HF range, 24-37 mm), dorsal body color coarsely grizzled, buffy brown, ventral body color grayish, tail bicolored and hirsute, skull (fig. 4, 6) with deep rostral fossa, mesopterygoid fossa with large and wide sphenopalatine vacuities (exposing orbitosphenoid), alisphenoid strut present, deep palatal fossae (complex posterolateral palatal pits), M2 with reduced mesoloph, $\mathrm{m} 1$ and $\mathrm{m} 2$ with reduced or absent mesolophid, central cartilaginous digit of distal baculum absent, and a unique chromosomal formula $(2 \mathrm{n}=58, \mathrm{FN}=70-72)$.

Karyology: The Cerradomys scotti karyotype exhibits a $2 \mathrm{n}=58$ and $\mathrm{FN}=70-72$ (table 7). The autosomal complement comprises seven biarmed pairs and 20 acrocentric pairs from large to small. The $\mathrm{X}$ chromosome is a large submetacentric and the $\mathrm{Y}$ a medium submetacentric (Bonvicino et al., 1999; Langguth and Bonvicino, 2002).

NATURAL History: Distinctly from other congeneric species (more associated with forest habitats, as gallery forest and "cerradão"), Cerradomys scotti is most frequently captured on the open habitats of Cerrado and on the ecotone between forested and open 
areas. Thus, based on tags, journal notes, and collector information this species is frequently observed on "campo sujo", "campo cerrado", and "cerrado sensu stricto". Langguth and Bonvicino (2002) stated that this species is also found on "veredas" and gallery forests, but less frequently than in more open vegetational habitats of the Cerrado. Cerradomys scotti is known to present scansorial ability (Alho and Villela, 1984).

Specimens Examined: BOLÍVIA: Santa Cruz: El Refugio Pampa, NE from camp: F: USNM 584583. Pozo Mario, Estância Las Conchas: M: CBF 6151 (photography). Santa Rosa de La Roca: M: AMNH 263872. BRAZIL: BAHIA: Fazenda Sertão do Formoso, Jaborandi: I: MN 61667-72. Distrito FedERAL: Brasília: I: FMNH 128313. Fazenda Água Limpa: M: UFPB 1925. Parque Nacional de Brasília: M: UnB 338, 346, 348, 922, 957; F: UnB 343, 347, 923, 924. Reserva Biológica de Águas Emendadas: M: UnB 488, 493, 527, 529, 535, 554, 574, 576, 586, 1314; M: UnB 499, 526, 553, 577; I: UnB 597, 603. Reserva Ecológica Roncador: M: UnB 954; F: UnB 939. GoIÁs: 3 km E Mambaí: F: UFPB 1917-8, 1920. 5/ $14 \mathrm{~km}$ N Alto Paraíso, Alto Paraíso: I: MN 61677, 61682, 61684, 61686, 61687. Fazenda Bandeirantes, Baliza: M: UnB 1171; F: UnB 1172; I: UnB 1173. Cerrado Alto, Catalão: M: UFMG 1683; F: UFMG 1685. Fazenda Fiandeira, Parque Nacional de Chapada dos Veadeiros, $65 \mathrm{~km}$ SSW de Cavalcante: I: MN 61675-6, 61679-80, 61688. Morro dos Cabeludos, Corumbá de Goiás: F: MN 44176 (holotype of C. scotti); I: MN 50379, 50380. Maranhão: Estiva, Município Alto Parnaíba: F: MPEG 22670. Mato Grosso: 264 km N Xavantina, Serra do Roncador: M: BMNH 81.444; F: BMNH 81.439, 81.443, 81.446. Escola Evangélica Buriti: M: UFMT JD 151, 166; F: UFMT JD 123, 141, 148, 156. Estação Ecológica Serra das Araras: M: UFMT JD 193, 197, 210; F: UFMT JD 195. Ponte Branca, Fazenda Altamira: F: UnB 1187, 1188. UHE Manso, Chapada dos Guimarães: M: UnB 610; F: UnB 626, 634, 868. UHE Manso, $100 \mathrm{~km} \mathrm{~N}$ de Cuiabá: M: UnB 801; F: UnB 800. Мато Grosso do Sul: Maracaju: I: MN 4414. Minas GeraIs: [Área 23,] Usina Hidroelétrica de Miranda, Uberlândia: M: UFMG 2851. Cerrado de Indianópolis, Indianópolis: M:
UFMG 1749, UFMG Miranda 51. Cerrado Fazenda Boa: F: UFMG 1746. Cerrado João Alonso, Perdizes: M: UFMG 1795-8, 1801-3; F: UFMG 1794, 1799, 1800. COPASA, Área de Proteção Ambiental Serra Azul, Mateus Leme: M: UFMG 1523. Coromandel, Cerrado do Gato Mourisco: M: UFMG 1684. Fazenda Capão Grande, Santa Juliana: M: UFMG 1804; F: UFMG 1805-6. Lagoa Santa: M: BMNH 88.1.9.5. Paracatu, Parque Acangau, M: UnB 1019, 1021, 1023. Usina Hidroelétrica de Igarapava, Conquista: I: UFMG 1623-4. PIaUi: Estação Ecológica de Uruçuí-Una: M: MZUSP 137, 161; F: MZUSP 344. Tocantins: Rio da Palma, Paranã: M: ARP 3836, 3843. PARAGUAY: CONCEPCION: $28 \mathrm{~km}$ S junction route $3 \&$ route 5 on route 3: M; MVZ 141890. Cordillera: $1.6 \mathrm{~km}$ S Tobati: M: UMMZ 126005; F: MVZ 145148. 20 km N Altos: M: MVZ 145147. Paraguari: Sapucay: M: BMNH 3.4.7.13, 4.1.5.12, MZUSP 1999, USNM 121389-91, 121393; F: BMNH 2.11.7.7, 3.2.3.8, USNM 121394-5.

\section{Cerradomys subflavus (Wagner, 1842)}

Mus vulpinus Lund, 1840: 279; type locality: "Lagoa Santa, Minas Gerais, Brazil". Pre-occupied by Mus vulpinus Brants 1827, a name associated with genus Holochilus.

Hesperomys subflavus Wagner, 1842: 362; type locality: "Brasilia", subsequently restricted to "Lagoa Santa, Minas Gerais, Brazil" by Cabrera (1961).

Mus vulpinoides Schinz, 1845: 193; renaming of Mus vulpinus Lund, 1840.

Calomys laticeps: Winge, 1888: 51 (erroneous name combination; see Musser et al., 1998: 263, 298).

Oryzomys subflavus: Thomas, 1901: 528.

C[erradomys] subflavus: Weksler et al., 2006: 8.

Type Locality: Lagoa Santa, Minas Gerais, Brazil; $19^{\circ} 37^{\prime} \mathrm{S}, 43^{\circ} 53^{\prime} \mathrm{W} ; 760 \mathrm{~m}$.

Geographic Distribution: Populations currently assigned to Cerradomys subflavus (figs. 1, 2) are distributed throughout the Brazilian states of Goiás, Minas Gerais, and São Paulo, usually associated with the interior highlands in Minas Gerais and São Paulo, and with the Central Brazilian Highland in Goiás.

Diagnosis: C. subflavus is characterized by medium to large body and tail size (HBL range, $120-179 \mathrm{~mm}$; TL range, $150-210 \mathrm{~mm}$; table 3), small feet (HF range, 31-34 mm), 
dorsal body color coarsely grizzled, buffy to orange brown, head color grayish, ventral body color grayish, skull (figs. 3, 5) with deep rostral fossa, mesopterygoid fossa with large and wide sphenopalatine vacuities (exposing orbitosphenoid), deep, narrow, and long palatal fossae (complex posterolateral palatal pits), eustachian tube short with a distinct medial bony lamina dorsal to carotid canal, central cartilaginous digit of distal baculum reduced, and a unique chromosomal formula $(2 \mathrm{n}=54, \mathrm{FN}=62)$.

KARYOLOGY: The Cerradomys subflavus karyotype shows $2 \mathrm{n}=54$ and $\mathrm{FN}=62$ (table 7, fig. 10). The autosome complement comprises five biarmed pairs (three large and two small) and 21 small acrocentric pairs. The $\mathrm{X}$ chromosome is a medium acrocentric and the $\mathrm{Y}$, a small acrocentric (Bonvicino et al., 1999; Langguth and Bonvicino, 2002).

Natural History: The Brazilian populations of Cerradomys subflavus are known to occur at the mesic habitats of Cerrado, in gallery forest and "cerradão", as well the patches of semideciduous forest of Brazilian highlands, and the coastal Atlantic Forest. On the other hand, museum tags of specimens from the Brazilian locality of Anápolis, Goiás, describe C. subflavus habitats as: "high dry grass, edge woods and farm"; "Brush and high grass-dry-hill-edge of woods-farm"; "edge of cane fields and woods-dry"; "edge of woods and dry grass"; "high dry grass-near woods"; "edge of corn field and woods"; "heavy grass, open woods, small stream"; "Edge of high grass, woods, and farms"; "Dry, high grass on hill-50 y[ar]ds. from woods"; "Capim seco [= Dry grass], near woods + farm, farm" (R.M. Gilmore, in museum tags at AMNH and MN). Cerradomys subflavus is predominantly a terrestrial species (Stallings, 1989), although it might eventually be captured in trees (Fonseca and Kierulff, 1989).

SPecimens ExAmined: BRAZIL: Bahia: Nova Viçosa: M: LV-MW 13. GoIÁs: Anápolis: M: AMNH 134633, 134640, 134655, 134660, MN 4338, 4345; F: AMNH 134629, 134636, 134650, 134785, MN 4347. Minas Gerais: Águas Claras, Ravena: M: UFMG 684, 686. BR 262, km 580, Ibiá: M: UnB 837. BR 262, km 609, Campos Altos: M:
UnB 815, 817, 821; F: UnB 836, 839. Belo Horizonte (includes Pampulha e Campus UFMG): M: UFMG 913, UFMG 55. Caqui, Barra Longa: M: UFMG 567. COPASA, Área de Proteção Ambiental Serra Azul, Mateus Leme: M: UFMG 1521, 1532-3; F: UFMG 1528, 1534. Coromandel: F: UFMG 6. E.P.D.A. PETI, Santa Bárbara: F: UFMG 85; I: UFMG 75. Fazenda Barreiro Grande, Pompeu: M: UFMG 459; F: UFMG 456. Fazenda EPAMIG, Governador Valadares: F: UFMG 383; I: UFMG 381-2. Fazenda Esmeralda, Rio Casca: M: UFMG 1200; F: UFMG 1201. Fazenda Triângulo Formoso, Buritizeiros: M: UFMG 1; F: UFMG 3 . Lagoa Santa (includes Fazenda Cavaia and Sítio Bairro Quebra): M: UFPB 1921, 2363-4, 2699, 2706, 3017; F: UFPB 1919, 2062, 2365 , 2700, 2710, BMNH 88.1.9.6; I: UFPB 1927. Mata do Eixo, Uberlândia (Usina Hidroelétrica de Nova Ponte): M: UFMG 1744; F: UFMG 1748, 1750. NW Nova Ponte (includes Mata do Edésio and Mata do João Lindolfo): M: UFMG 2869, 2870. Ouro Preto: F: UFMG 602. P. E. Rio Doce, $13 \mathrm{~km}$ E Marliéria (includes P. E. Rio Doce, Marliéria): M: UFMG 570, YL 97, 1120; F: UFMG 1152, UFMG 2858. P. E. Rio Doce (includes P. E. Rio Doce and P. E. Rio Doce, Coronel Fabriciano): M: UFMG 139. P. E. Rio Preto, 15 km S São Gonçalo do Rio Preto: M: UFMG 2852-3; F: UFMG LPC 70, YL 68. Prados, Biquinha: M: UFMG 448; F: UFMG 449. Santa Luzia (includes Fazenda Baroneza e Rio Bagaço): M: UFMG 432, 444, 445; F: UFMG 441-2, 536. Sete Lagoas (includes EMBRAPA e Fazenda Baroneza): M: UFMG 443, 576, 577, 599; F: UFMG 556, 607. Usina Hidroelétrica de Igarapava, Conquista: I: UFMG 23. Val da Lagoa, Serra do Cipó: M: UFMG 646. Vargem do Retiro, Ribeirão Mascates, Parque Nacional da Serra do Cipó: M: MN 31393, 31435. São Paulo: Avanhandava: F: MZUSP 2872. Barreiro Rico, Santa Maria da Serra: F: UFPB 160. Campininha, Mogi-Guaçu, Reserva Biológica de Mogi-Guaçu: M: MZUSP 13591. Cássia dos Coqueiros: I: MZUSP 25587. Dois Córregos: M: MZUSP 7050. Franca: M: MZUSP 820-1. Itapetininga: M: UFMG MAM 182; F: UFMG MAM 179. Ituverava: M: MZUSP 2956; F: MZUSP 2955. Salto de Pirapora: M: MZUSP 24599. 


\section{Cerradomys vivoi, new species}

Figures 1-3, 5, 7, 9-11; tables 1 and 2

Holotype: MN 35898, an adult male collected by E. Hingst-Zaher and M. Lara (original field number $\mathrm{EDH} 60$ ), on 29 December, 1992. The holotype consists of an undamaged skin, skull with fractured left zygomatic arch and right auditory bulla missing, and postcranial skeleton. ${ }^{3}$ The cell suspension of bone marrow in Carnoy's fixative (methanol:acetic acid) and the livertissue aliquot preserved in ethanol are housed at Laboratório de Biologia e Parasitologia de Mamíferos Reservatórios Silvestres, Instituto Osvaldo Cruz-FIOCRUZ, under original field number EDH 60. Cytochrome $b$ DNA data are available in GenBank under the accession number AF181275.

External and selected skull dimensions of holotype are: HBL, 152; LT, 180; HF, 34 (including claw); Ear, 21; Wt, 82.15; CIL, 32.23; LD, 9.62; LM, 4.88; BM1, 1.40; LIF, 6.82; PB, 5.45; BR, 6.56; LN, 13.79; LPB, 5.89; HB, 10.36; LIB, 5.19; CZL, 25.10; OL, 12.62.

PARATYPES: We assign all specimens herein examined (see below) as paratypes of $C$. vivoi.

Type Locality: The Cerradomys vivoi holotype was captured in coastal Atlantic Forest, near Itabuna in the Brazilian state of Bahia. The type locality is situated at Parque Zoobotânico da Comissão Executiva do Plano da Lavoura Cacaueira (CEPLAC), situated $6 \mathrm{~km} \mathrm{E}$ of Itabuna by road, state of Bahia, Brazil, at $14^{\circ} 48^{\prime} \mathrm{S}, 39^{\circ} 16^{\prime} \mathrm{W}$, on sea level (figs. 1, 2).

Distribution: Known collection localities of C. vivoi are distributed in the Brazilian states of Minas Gerais, Bahia, and Sergipe. In the state of Minas Gerais, distribution records are restricted to the northern portion of this state, around Rio Jequitinhonha, and Rio São Francisco and its right bank tributaries. In Bahia, sampling localities of $C$. vivoi extend from the coastal region to the eastern bank of Rio São Francisco. In Sergipe, the only recorded site of collection is in the coastal

\footnotetext{
${ }^{3}$ The specimen MN 35898 was selected as holotype, because it is the only available specimen with karyotype and tissue sample.
}

region, near the mouth of Rio São Francisco (figs. 1, 2).

ETYMOLOGY: This species is named after Dr. Mario de Vivo, mammal curator of Museu de Zoologia da Universidade de São Paulo, for his outstanding contribution to the development of mammalogy in Brazil.

Diagnosis: Cerradomys vivoi is characterized by intermediate body size, short and dense dorsal pelage, dorsal body color orange grizzled with brown, head color grayish, ventral body color grayish or slightly yellowish, skull with long and wide sphenopalatine vacuities, alisphenoid strut absent, deep palatal fossae (complex posterolateral palatal pits), and a unique chromosomal formula $(2 \mathrm{n}=50$, $\mathrm{FN}=62-64$ ).

Morphological Description: Head and body medium sized (table 2); tail length longer than head and body $(127 \%-150 \%$ of head and body length); hind feet moderately narrow and long ( $21 \%-24 \%$ of head and body length), with large and fleshy interdigital, thenar, and hypothenar pads; pinnae rounded and small (12.5\%-16\% of head and body length). Dorsal pelage short and dense (table 1), consisting of short and dense underfur (wool hairs; thin, wavy, short) and longer and lax overfur (guard and cover hairs; thick, long). Dorsal body color buffy orange densely grizzled with black; wool hairs (range: 6-11 mm) with basal part grayish and distal part (1/10 of total length) orange or brown; cover hairs long (range: 9-15 mm), with distal 1/4 dark brown with a subterminal orange band; guard hairs sparse and long (range: 14-20 mm), with distal half entirely black or dark brown. Anterior half of head (until eyes) covered with gray-based and white- or buffy-tipped hairs, clearly distinct from color of posterior half of head and dorsal body fur. Ventral pelage composed of wool, cover and guard hairs, with individual hairs gray at the base and tipped with white, buff, or yellow; general ventral color grayish, buffy, or yellowish, slightly grizzled, and distinctively lighter than dorsal pelage. Flanks bright orange; banded cover hairs and dark guard hairs rare. Mystacial vibrissae long, reaching but not surpassing pinnae when laid back. Tail slightly bicolored, covered with short, sparse brown hairs and scales on dorsal surface and 


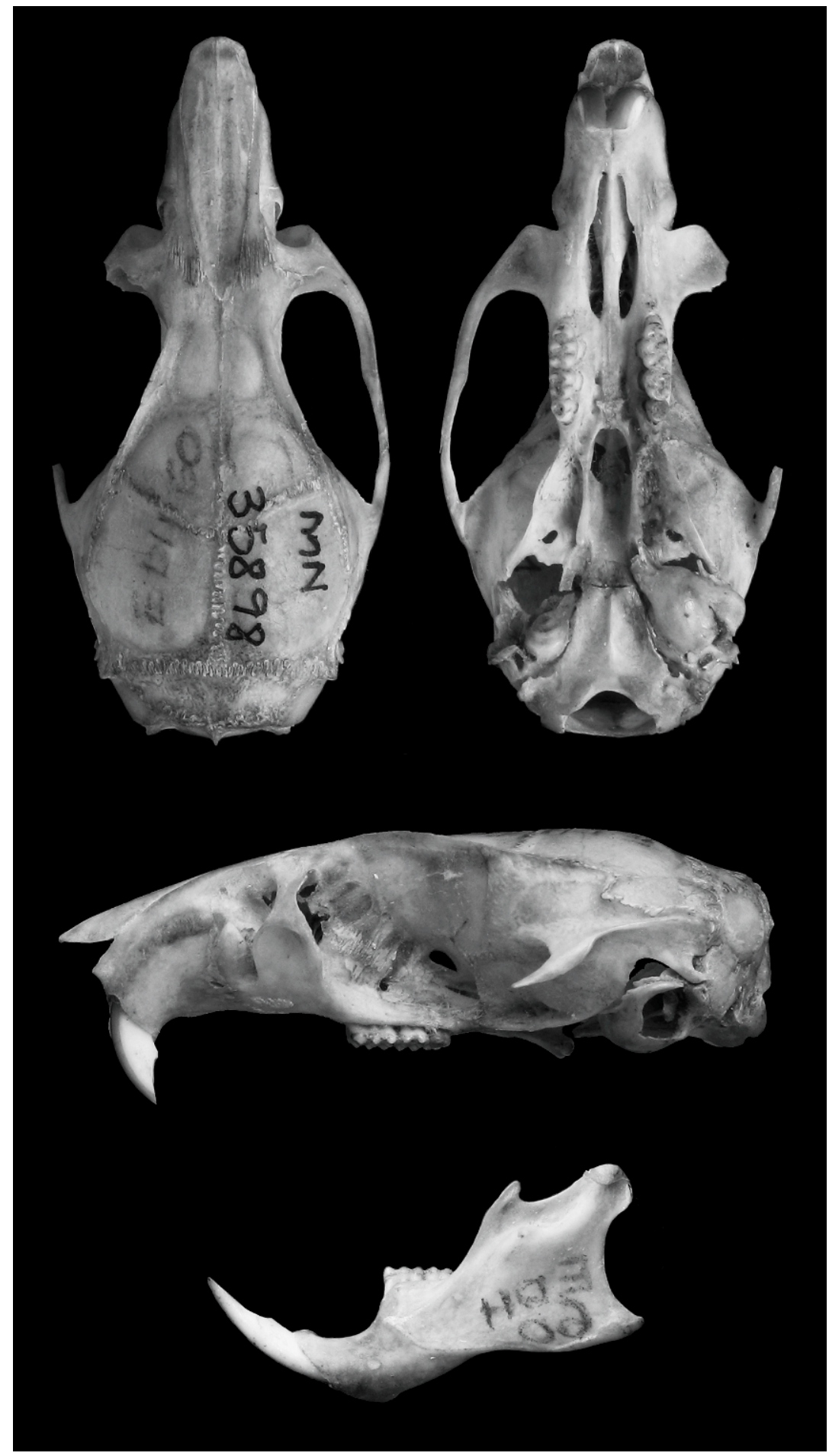

Fig. 9. Dorsal, ventral, and lateral cranial views of the holotype of Cerradomys vivoi (MN 35898; CIL, $32.2 \mathrm{~mm})$. 

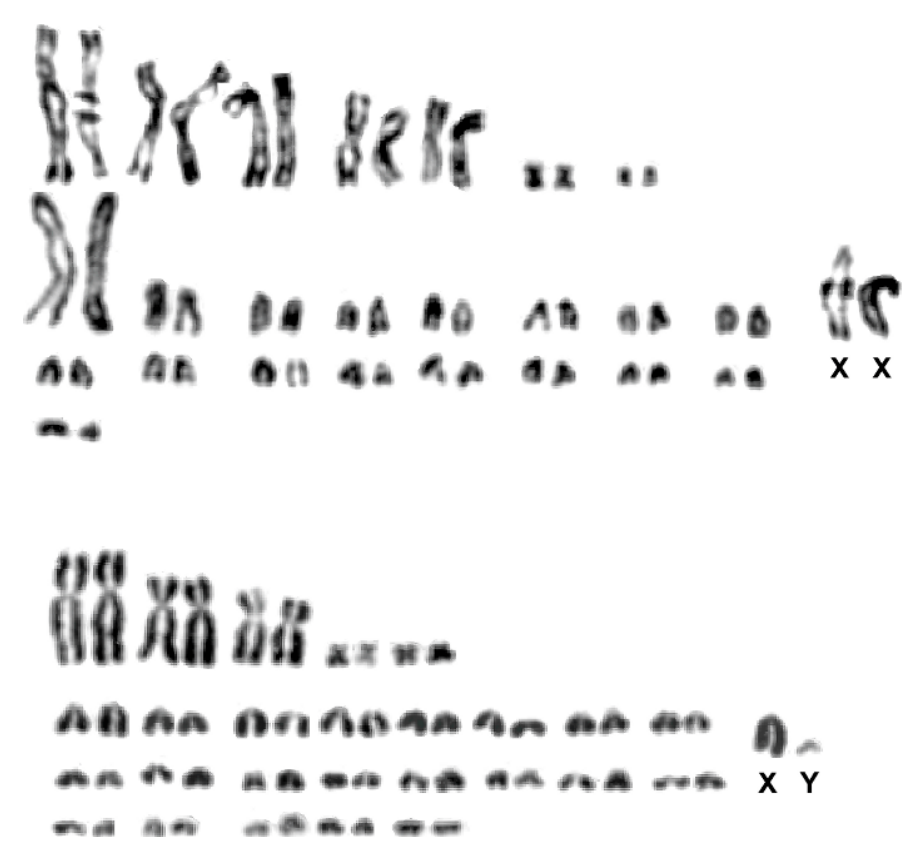

Fig. 10. Karyotypes of female C. vivoi (MN 63377) from Caetité, Bahia, Brazil (above) and of male $C$. subflavus (LV-MW 13) from Nova Viçosa, Bahia, Brazil (below); both prepared in conventional stain.

unpigmented hairs and scales on ventral surface. Dorsal surface of hind foot predominantly white, covered with short hairs, with $3 /$ 4 distal portion white and basal $1 / 4$ grayish or washed brown; ungual tufts sparse, shorter than claws especially on digit I; ventral surface naked, unpigmented, with four interdigital pads and two tarsal pads (thenar and hypothenar). Pinnae covered internally with short orange hairs and externally with orange, brown-tipped hairs.

Skull size intermediate (tables 1, 2; figs. 3, 5). Rostrum long, broad, tapering, with inflated capsular projection of nasolacrimal foramen, and flanked by deeply excavated zygomatic notches; interobital region long and narrow (table 2), converging anteriorly, with dorsolateral margins with sharp and welldeveloped supraorbital crests; braincase oblong, with prominent temporal crests. Zygomatic plate (in lateral view) projected forward, with dorsal free margin rounded and anterior margin straight or slightly concave, and zygomatic spine absent. Incisive foramina long (averaging about $74 \%$ of length of diastema), with lateral margins concave and

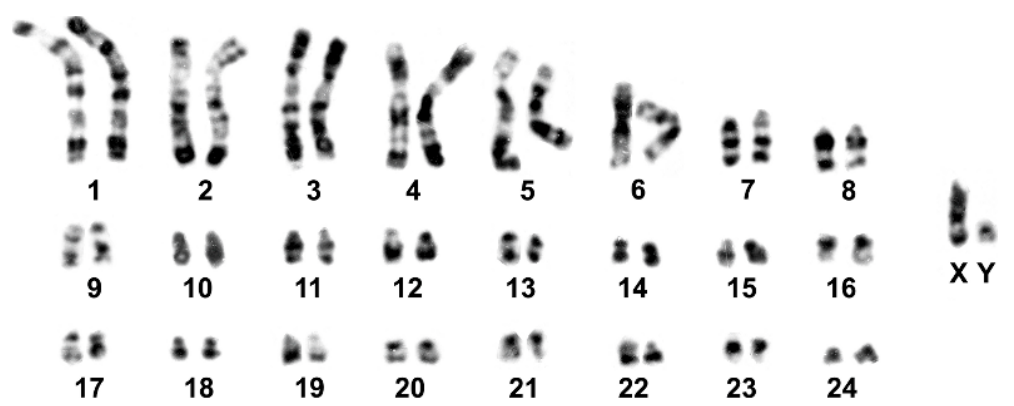

Fig. 11. G-band karyotype of the holotype of C. vivoi (male MN 35898) from Parque Zoobotânico da Comissão Executiva do Plano da Lavoura Cacaueira (CEPLAC), Itabuna, Bahia, Brazil. 
diverging posteriorly, wider posteriorly; posterior margins extending or not between the alveolus of upper first molars. Palate long and wide (sensu Hershkovitz, 1962); posterolateral palatal pits numerous and complex, recessed in moderately deep palatal fossae; palatal excrescences rarely present. Mesopterygoid fossa narrow, with anterior margin rounded or slightly acute, not reaching the alveolus of M3; bony roof of mesopterygoid fossa perforated by long and wide sphenopalatine vacuities, exposing the orbitosphenoid. Alisphenoid strut absent (buccinator-masticatory foramen and ovale foramen confluent). Postglenoid foramen large and nearly semicircular in shape separated from small subsquamosal fenestra (absent in specimens with moderate to heavy tooth wear), by a wide hamular process of squamosal. Tegmen tympani weakly overlapping squamosal; posterior suspensory process of squamosal absent. Ectotympanic bullae globose; eustachian tube short, with distinct medial laminae in a few specimens; stapedial process short and wide, overlapping squamosal; bony process dorsal to stapedial process present, overlapping squamosal.

Mandible long and deep (fig. 9); coronoid process large, falciform or triangular, nearly equal to condyloid process; superior notch shallow; angular process short, not surpassing the condyloid process posteriorly; inferior notch shallow; capsular process of lower incisor well developed.

Incisors, upper and lower molars as for the genus (no mesoloph/mesolophid reduction was observed in C. vivoi). Mammary counts and soft anatomy (stomach and glans penis) as described for the genus.

KARYOLOGY: The holotype of Cerradomys vivoi (MN 35898), as well as seven specimens collected in Caetité, Bahia, and Juramento, Minas Gerais, showed a karyotype with $2 \mathrm{n}=$ 50 and $\mathrm{FN}=62-63$ (table 7, figs. 10, 11). The autosomal complement comprises seven biarmed pairs (1 large, 4 medium, and 2 small pairs) and 17 acrocentric pairs (1 large and 16 small pairs). The $\mathrm{X}$ chromosome is a mediumsized acrocentric and the Y, small-sized. Variation in autosome fundamental number is due to pericentric inversion affecting a medium acrocentric. The G-banding pattern of $C$. vivoi allowed the unequivocal identification of homologues in autosome pairs and sex chromosomes (fig. 11). One male specimen (LV-FC22) and one female specimen (MN 61661) showed $2 \mathrm{n}=50, \mathrm{FN}=63$, due to a pericentric inversion involving one chromosome of a medium autosome pair.

Natural History: In the CerradoCaatinga transitional areas, Cerradomys vivoi inhabits secondary semideciduous and gallery forests, as well as arboreal Caatinga (all information on the natural history of this species is based on Hingst et al., 1997, except where noted). In the same region this species was trapped along with Gracilinanus agilis, Marmosops incanus, Monodelphis domestica, Calomys expulsus, Oligoryzomys fornesi, Oligoryzomys nigripes, Oligoryzomys stramineus, Nectomys rattus, Rhipidomys sp., Wiedomys pyrrhorhinos, and Thrichomys apereoides. The diet of $C$. vivoi consists mainly of vegetal material and arthropods. The only ectoparasite species found in C. vivoi is the mite Gigantolaelaps vitzhumi (Acari: Laelapidae).

In the Atlantic Forest, at Una Biological Reserve located in southern Bahia (Pardini, 2004), Cerradomys vivoi was captured by $\mathrm{R}$. Pardini (unpubl.; in litt., A.R. Percequillo archives), who provided the following account on this species abundance and habitat preference:

I had performed 36,288 trap nights employing Sherman traps and 10,368 pitfall nights using $351 .[=$ liters $]$ buckets, an effort equally divided through six habitats ("cabrucas" [disturbed canopy forests, mixed with cacao plantations: the understory is removed and replaced by cacao plants], "capoeiras em estadio inicial a medio-inicial de regeneracao" [disturbed forests in initial and inicial/ advanced stage of regeneration], and interior and edge of mature forest with more than 1,000 ha and interior and edge of mature forest less than $100 \mathrm{ha})$. I captured 9 $O$ [ryzomys $]$. subflavus $[=$ Cerradomys vivoi $]$, 1 in "cabruca" and 8 in "capoeiras". Moreover, in preliminary un-standardized sampling, . . . I captured few individuals. . . of subflavus $[=C$. vivoi $]$ in open abandoned pasture areas.... Considering the smaller effort of this sampling, the number of 
individuals captured ( 2 or 3 ) was comparatively larger. Considering these numbers, I believe that subflavus $[=C$. vivoi $]$ is absent or very rare in mature forests, including the edges, occurs in disturbed forests in initial stages of regeneration or other disturbed forests (as cabrucas) and that is probably more common in open areas. It is noteworthy that even in "capoeiras" or "cabrucas" they are relatively rare, since only 8 individuals were captured in 350 captures in "capoeiras" and only 1 specimen was captured in 299 captures in "cabrucas". . . .

In the same geographical area, Cerradomys vivoi was captured along with Didelphis aurita, Gracilinanus microtarsus, Marmosa murina, Marmosa sp., Marmosops incanus, Metachirus nudicaudatus, Micoureus demerarae, Monodelphis americana, Sciurus ingrami, Akodon cursor, Blarinomys breviceps, Euryoryzomys russatus, Hylaeamys laticeps, Nectomys squamipes, Oecomys sp., Oligoryzomys sp., Rhipidomys mastacalis, Thaptomys sp., and Phyllomys sp. (Pardini, 2004).

Specimens Examined: BRAZIL: Bahia: Andaraí: F: UFPB 2376. Caetité: MN 63377, 63381. CEPLAC, E de Itabuna: M: MN 35898 (holotype of $C$. vivoi). Fazenda Bolandeira, $10 \mathrm{~km}$ S Una: M: UFMG MAS 1, MAS 31, MAS 46, 2854, 2856, YL 21; F: UFMG LPC 104, 2215, 2855, YL 103. Fazenda Lagoa D'Água, Serrinha, Feira de Santana: I: BMNH 1986.1596. Fazenda Massapê, SW Serrinha: F: UFMG YL 208. Fazenda Santa Rita, E Andaraí: M: UFMG 2859-61, 2863-5, LPC 221, 225; F: UFMG 2862, 2866, LPC 224. Gandú: F: UFPB 2063. Lagoa de Itaparica: F: MZUSP 28889, 28890. Mirorós: M: UnB 137-8. Mucujê: M: MZUSP 27403. Reserva Biológica de Una: M: MZUSP RP 1785, 2954. Rio Unamirim, $14 \mathrm{~km}$ W Valença: M: UFPB 540, 541. Sebastião Laranjeiras: F: UnB 1403. Una: M: UFMG MAS 32. Minas GeraIS: Fazenda Canoas, Juramento: M: MN 61662, 61664, LV-FC 22; F: MN 61661, 61663, LV-FC 148; I: MN 61665. Itaobin: F: UFMG 907. Itinga: M: UFMG 1453-4. Jequitinhonha: M: UFMG 1458. Riacho Mocambinho, Jaíba: M: MN 34433, 34436; F: MN 34432, 34434. Ribeirão Contendas, Cristália: F: UFMG 58. SERgiPe: Fazenda
Capivara, $7 \mathrm{~km}$ SE Brejo Grande: M: MN 30694; F: MN 30587-8.

\section{SPECIES Limits AND COMPARISONS}

Morphologic Variation: Cerradomys vivoi differs from $C$. maracajuensis and $C$. marinhus by its shorter, rich orange-brown dorsal pelage, when compared to the longer and denser yellow-brown dorsal pelage of the latter two taxa (table 1). Additionally, the anterior half of dorsal head pelage is distinctively grayish to yellow gray in $C$. vivoi, whereas in $C$. maracajuensis and $C$. marinhus its color is the same as the dorsal body pelage. The ventral pelage in $C$. vivoi varies from grayish white to grayish yellow; conversely, in both $C$. maracajuensis and $C$. marinhus this region exhibits an intense yellow or buffy color. Cerradomys vivoi also differs from $C$. maracajuensis and $C$. marinhus by the presence of posterolateral palatal pits recessed in deeply excavated fossae, whereas in the latter species pits are recessed in shallow palatal fossae. Another cranial feature that discriminates $C$. vivoi from C. marinhus and C. maracajuensis is the roof of mesopterygopid fossa, which is perforated by long and wide sphenopalatine vacuities, largely exposing the orbitosphenoid in $C$. vivoi. On the other hand, both $C$. maracajuensis and $C$. marinhus are characterized by shorter vacuities restricted to presphenoid (in all 92 Bolivian specimens of $C$. maracajuensis surveyed for this trait) or by a completely ossified roof of mesopterygoid fossa (in $77 \%$ of 31 Paraguayan and Brazilian specimens of $C$. maracajuensis).

Cerradomys vivoi can be easily distinguished from $C$. scotti and from the holotype of $C$. andersoni (CBF 6151) by dorsal body color, which is buffy yellow with brown in the latter two species. Cerradomys vivoi can also be recognized from $C$. scotti and $C$. andersoni in some tail traits (table 1): C. vivoi exhibits a moderately hirsute tail, ranging from uniform to bicolored dorsoventrally, whereas both $C$. andersoni and C. scotti present strongly hirsute and sharply bicolored tails. Cranial differences are also conspicuous: $C$. scotti, as well the holotype of $C$. andersoni, are characterized by the presence of alisphenoid strut in $84 \%$ of specimens $(\mathrm{n}=92)$, while this trait is 
consistently absent in $C$. vivoi. Palatal excrescences are also present in $C$. scotti and absent in $C$. vivoi (small in the young specimen of $C$. andersoni). Dental morphological traits also are distinctive regarding $C$. vivoi and $C$. scotti: the mesoloph is reduced in M2 $(22 \%$ of 78 examined specimens) and the mesolophid is consistently absent from $\mathrm{m} 1$ and $\mathrm{m} 2$ (in all surveyed specimens for this trait) in C. scotti (also in C. andersoni); conversely, both mesoloph and mesolphid are present in all specimens of $C$. vivoi.

The cranium of $C$. vivoi is readily distinguished from $C$. subflavus and C. langguthi by its long and wide sphenopalatine vacuities, largely exposing the orbitosphenoid, while $C$. subflavus shows long and narrow vacuities, barely exposing the orbitosphenoid and $C$. langguthi exhibits short and narrow sphenopalatine vacuities.

Morphometric Variation: Cerradomys scotti, C. marinhus, and C. maracajuensis can be readily and unambiguously distinguished from $C$. vivoi by discrete qualitative traits (see also table 3 for external and cranial measurements). In contrast, $C$. vivoi is most similar to C. subflavus and C. langguthi, with more subtle cranial differences. Therefore, all our subsequent analyses (morphometric, karyologic, and molecular) were restricted to these three forms in order to emphasize the differences among them.

Sexual dimorphism in species of genus Cerradomys is not an important component of variation in cranial morphometrics (Brandt and Pêssoa, 1994; Percequillo, 1998), a pattern recurrent in oryzomyine (Goldman, 1918; Musser and Williams, 1985) and other sigmodontine rodents (Voss, 1988: 362; Carleton and Musser, 1989; Voss and Marcus, 1992). Consequently, we combined males and females for all subsequent univariate and multivariate statistical analyses herein performed.

Among external measurements, $C$. vivoi and C. langguthi differ significantly from $C$. subflavus in body length (one-way ANOVA, df = $160, \mathrm{~F}=40.05, \mathrm{p}<0.001)$ and weight $(\mathrm{df}=$ $134, \mathrm{~F}=71.16, \mathrm{p}<0.001)$. With respect to cranial measurements, 7 of 15 variables significantly discriminated the three species: CIL (one-way ANOVA, $\mathrm{df}=159, \mathrm{~F}=84.73$, $\mathrm{p}<0.001), \mathrm{HB}(\mathrm{df}=155, \mathrm{~F}=51.03$,
TABLE 4

Results of Principal Components Analysis Employing the Adults of Cerradomys

Specimens included: C. subflavus $(\mathrm{n}=38)$, C. vivoi $(\mathrm{n}=31)$ and $C$. langguthi $(\mathrm{n}=32)$.

\begin{tabular}{lcrr}
\hline \hline & \multicolumn{3}{c}{ Eigenvectors } \\
\cline { 2 - 4 } Variable & First & Second & \multicolumn{1}{c}{ Third } \\
\hline CIL & 0.2908 & -0.1028 & 0.0057 \\
LD & 0.3714 & -0.4017 & -0.0203 \\
LM & 0.1493 & 0.3333 & -0.0062 \\
BM1 & 0.1869 & 0.4185 & 0.1576 \\
LIF & 0.3167 & -0.4010 & 0.0771 \\
PB & 0.2446 & 0.2917 & 0.1184 \\
BR & 0.0783 & 0.1653 & 0.8249 \\
LN & 0.2389 & -0.2505 & 0.2594 \\
LPB & 0.2007 & 0.0165 & -0.2752 \\
HB & 0.2047 & 0.0341 & -0.0469 \\
LIB & 0.3288 & 0.3887 & -0.3439 \\
ZB & 0.2576 & 0.0296 & 0.0462 \\
CZL & 0.2848 & -0.0521 & 0.0006 \\
OFL & 0.3171 & -0.0855 & -0.0655 \\
BB & 0.2421 & 0.2060 & -0.0661 \\
Eigenvalue & 0.023 & 0.0054 & 0.0033 \\
\% Variance & 54.03 & 12.92 & 7.88 \\
\hline
\end{tabular}

$\mathrm{p}<0.001)$, LIB (df $=179, F=84.08, p$ $<0.001), \mathrm{ZB}(\mathrm{df}=152, \mathrm{~F}=65.87, \mathrm{p}<0.001)$, CZL (df $=163, F=91.87, p<0.001)$, OFL $(\mathrm{df}=179, \mathrm{~F}=123.31, \mathrm{p}<0.001)$, and $\mathrm{BB}(\mathrm{df}$ $=162, \mathrm{~F}=104.18, \mathrm{p}<0.001)$. All cranial measurements exhibited differences among these three species, with $C$. subflavus significantly larger, and the two other species of similar size (table 2). For those variables significantly different among the three species, C. vivoi is of intermediate size, while $C$. subflavus is consistently the most robust, and C. langguthi is always the smallest (table 2).

Principal component analysis confirmed that size was an important characteristic separating the three species. The first principal component is responsible for more than $50 \%$ of the observed variance (table 4). Moreover, all eigenvectors were positively related to the greatest variation axis. Some overlapping can be observed along the first axis (fig. 12), especially between the two smaller species, $C$. vivoi and $C$. langguthi.

Discriminant analysis using log-transformed cranial measurements (fig. 13) separated the three species along the first and second canonical axes. OL, BB, and CIL were 


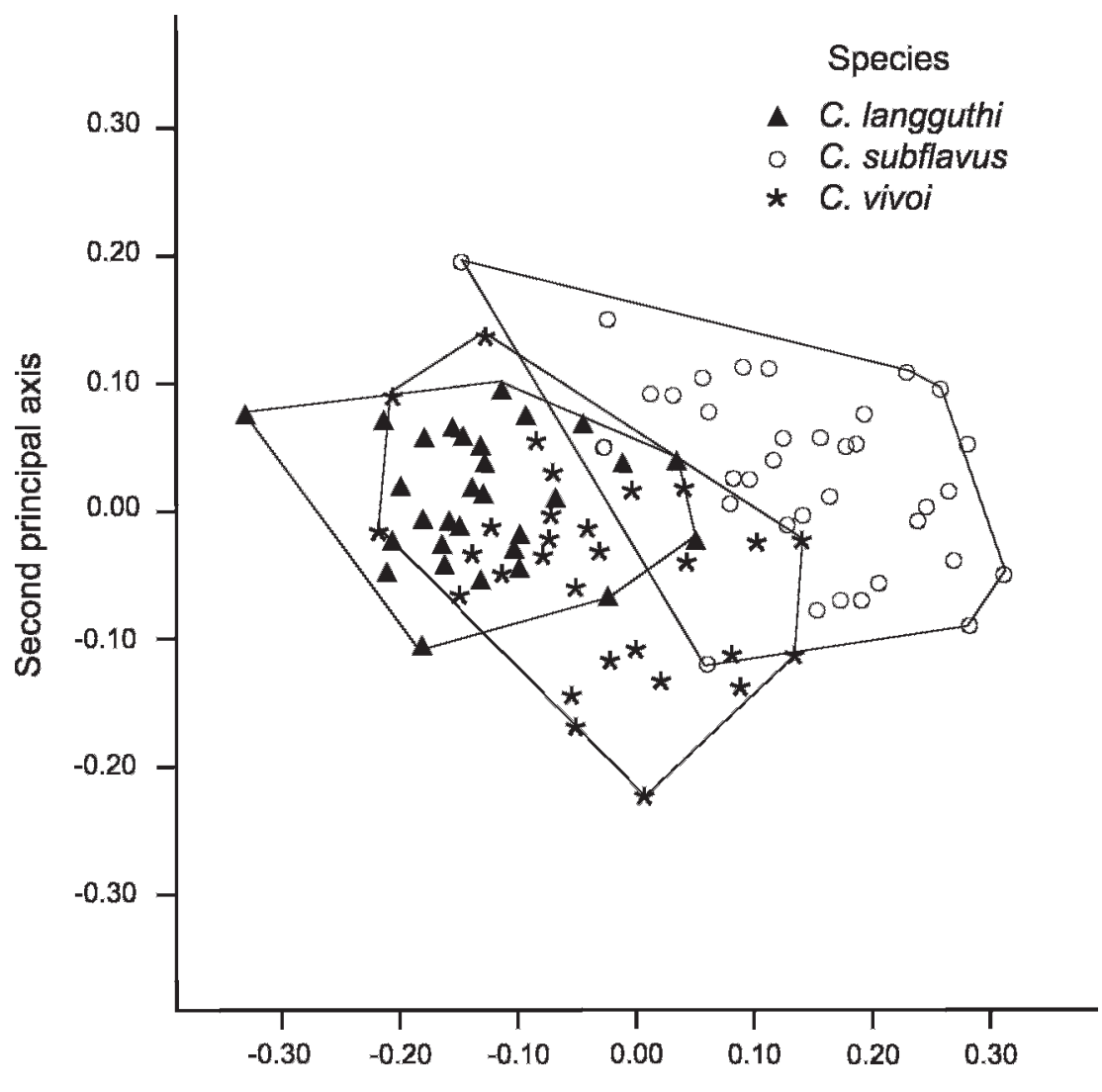

First principal axis

Fig. 12. Individual specimen scores based on log-transformed values of 15 cranial measurements, projected onto the first and second principal components extracted from analysis of adult specimens of three species of genus Cerradomys: C. subflavus, C. vivoi, and C. langguthi. Results of principal components analysis are in table 4.

the variables that mostly contributed to separation on first and second axis, respectively (table 5). Mahalanobis $\mathrm{D}^{2}$ distances between species were all significant (table 6).

KaRYOlOGIC VARIATION: Karyologic data reinforced the uniqueness of Cerradomys vivoi with respect to other species of the genus (table 7). When compared to $C$. subflavus, karyotypes were similar, since both species shared the same fundamental number. However, this resemblance is only apparent because they differed in diploid number and chromosome morphology. Complex rearrangements were responsible for these differences (fig. 10): C. subflavus has three large and two small biarmed chromosome pairs, while C. vivoi has two extra medium-sized biarmed chromosome pairs. Furthermore, $C$. vivoi exhibits a large acrocentric pair, the largest of its autosomal complement, without a recognizable counterpart in the $C$. subflavus complement, composed only of small-sized acrocentric pairs.

A similar $2 \mathrm{n}=50$ and $\mathrm{FN}=64$ karyotype was previously reported for specimens collected within the distribution range of Cerradomys vivoi: specimens from localities from central Bahia, namely Jacobina, Andaraí, Morro do Chapéu, and Mucugê (Percequillo, 1998) and from Sergipe (Andrades-Miranda et al., 2002). Moreover, a $2 \mathrm{n}=50$ and $\mathrm{FN}=62$ karyotype was found in specimens from northern Minas Gerais, Mocambinho (J. A. Oliveira, personal commun.). Quantitative and qualitative anal- 


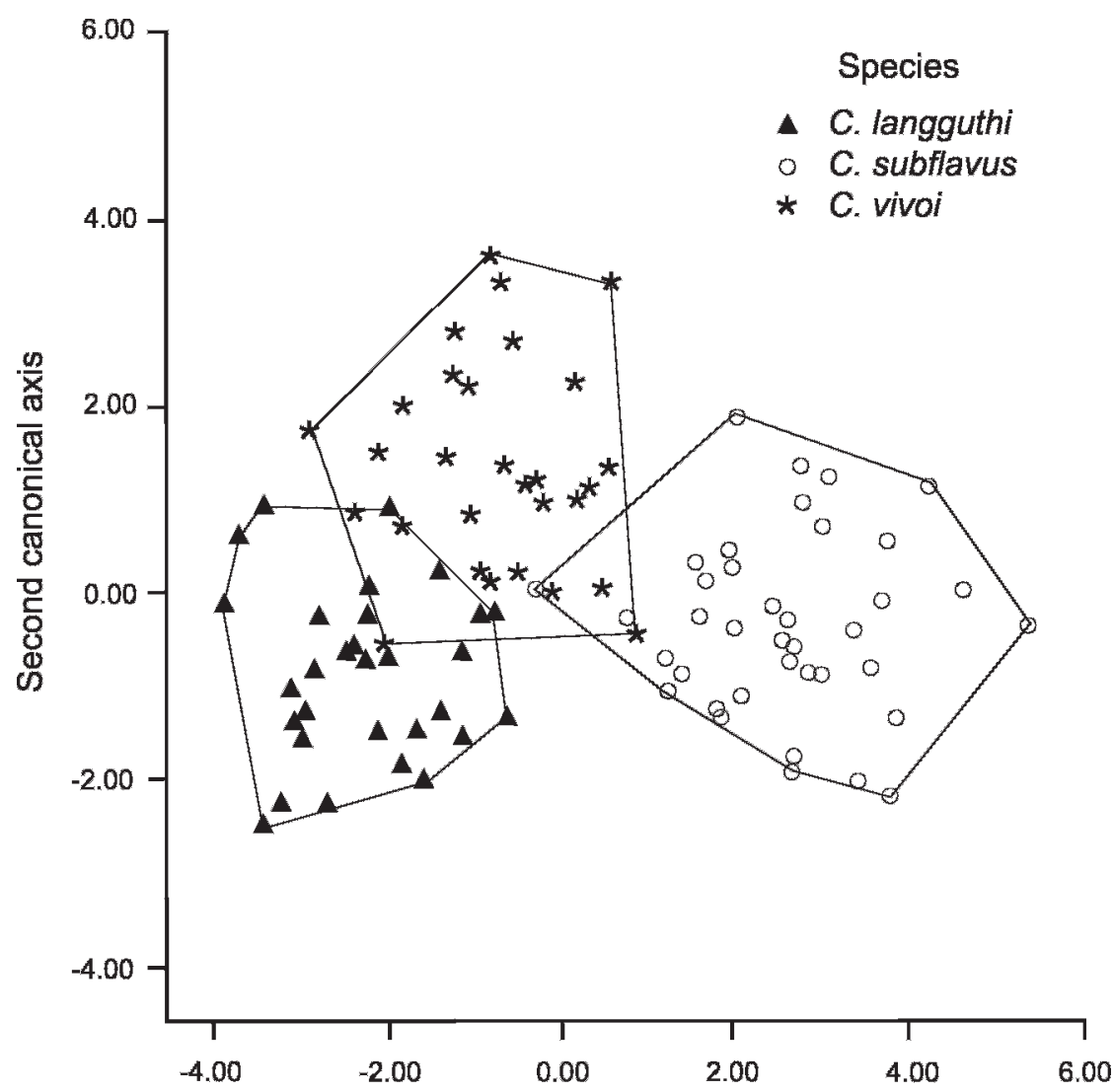

First canonical axis

Fig 13. Individual specimen scores based on log-transformed values of 15 cranial measurements and projected onto the first and the second canonical variates derived from discriminant function analysis of the three species of genus Cerradomys: C. subflavus, C. vivoi, and C. langguthi. Results of discriminant analysis are in table 5.

yses of voucher specimens from Mucugê (MZUSP 27403) and Mocambinho (MN 34432-4, 34436) and non-karyotyped specimens from Andaraí (UFPB 2376) allowed us to identify them as C. vivoi.

Some karyologic similarities were observed between $C$. vivoi and $C$. langguthi, which are characterized by a $2 \mathrm{n}=48-50$ and $\mathrm{FN}=56$. This intrapopulational polymorphism overlaps with the known diploid number of $C$. vivoi $(2 \mathrm{n}=50)$, but not with its fundamental autosome number $(\mathrm{FN}=64)$. However, $C$. vivoi was not variable in diploid number in samples from Bahia and Minas Gerais, south of Rio São Francisco (there is no available information of samples from Sergipe). Moreover, the morphologic distinctiveness of the autosomal complement between the samples from north of Rio São Francisco (herein C. langguthi) and C. vivoi allows for the recognition of both forms as separate species.

Molecular Variation: Genetic distance estimates between $C$. vivoi and $C$. subflavus were smaller $(1.7 \%-2.0 \%)$ than between other species pairs of Cerradomys (table 8). Maximumparsimony analyses placed Scotinomys and Neotoma apart from the oryzomyine species (fig. 14). The oryzomyines formed a trichotomy consisting of Nectomys genus, Sooretamys angouya, and a well-supported monophyletic group corresponding to Cerradomys species.

Within Cerradomys, the clade formed by $C$. maracajuensis and $C$. marinhus is the sister group to the remaining species of the genus: a 
TABLE 5

Results of Discriminant Analysis Employing Only Adults of Cerradomys

Specimens included: C. subflavus $(\mathrm{n}=38)$, C. vivoi $(\mathrm{n}=31)$ and $C$. langguthi $(\mathrm{n}=32)$.

\begin{tabular}{|c|c|c|}
\hline \multirow[b]{2}{*}{ Variable } & \multicolumn{2}{|c|}{ Canonical variates } \\
\hline & First & Second \\
\hline CIL & 0.79942 & 0.089374 \\
\hline LD & 0.585741 & 0.302316 \\
\hline LM & 0.707794 & -0.28913 \\
\hline BM1 & 0.569545 & -0.47175 \\
\hline LIF & 0.605877 & 0.301966 \\
\hline PB & 0.689085 & -0.37357 \\
\hline BR & 0.133541 & -0.38795 \\
\hline LN & 0.357743 & -0.11588 \\
\hline LPB & 0.403198 & 0.415764 \\
\hline HB & 0.612656 & 0.132083 \\
\hline LIB & 0.757297 & -0.07327 \\
\hline ZB & 0.760458 & -0.20443 \\
\hline CZL & 0.838757 & 0.070572 \\
\hline $\mathrm{OL}$ & 0.852912 & 0.137352 \\
\hline $\mathrm{BB}$ & 0.854506 & 0.096313 \\
\hline Canonical correlation & 0.90 & 0.66 \\
\hline Eigenvalue & 4.50 & 0.79 \\
\hline$\%$ Variance & 75.75 & 24.25 \\
\hline
\end{tabular}

clade joining $C$. scotti and a clade grouping Cerradomys langguthi, Cerradomys vivoi, and C. subflavus. The topology of this latter clade is well resolved, with Cerradomys langguthi emerging as a sister taxon to a monophyletic group formed by $C$. subflavus and Cerradomys vivoi.

\section{SUMMARY, COMPARISONS, AND DISCUSSION}

Unlike other Brazilian species of Cerradomys (C. scotti, C. maracajuensis, and $C$. marinhus), $C$. vivoi, $C$. subflavus, and $C$. langguthi do not exhibit discrete autapomorphic diagnostic traits. On the contrary, as several sigmodontine rodents (see Patton et al., 2000; Bonvicino, 2003; D’Elía and Pardiñas, 2004; Gonçalves et al., 2005; Emmons and Patton, 2005; Percequillo et al., 2005) these species are diagnosed by a unique combination of character states, together with karyologic, morphometric, and molecular evidence.

Cerradomys species are characterized by a remarkable karyologic divergence (see Langguth and Bonvicino, 2002; Bonvicino, 2003); current
TABLE 6

Mahalanobis D2 Distances (above diagonal) and Their Corresponding F-values (below)

Computed among the three species of Cerradomys, based on 15 skull measurements of 115 adult specimens. All values are significant at $\mathrm{p}=0.0001$. $\mathrm{df}=15 / 98$.

\begin{tabular}{lccc}
\hline \hline \multicolumn{1}{c}{ Species } & C. subflavus & C. vivoi & C. langguthi \\
\hline C. subflavus & 0 & 13.99 & 24.01 \\
C. vivoi & 13.65 & 0 & 6.74 \\
C. langguthi & 23.83 & 6.06 & 0 \\
\hline
\end{tabular}

recognized species, including $C$. vivoi and $C$. langguthi are clearly diagnosed by diploid and/or fundamental numbers, and by the morphology of autosomes and the sex chromosomes.

The combination of uni- and multivariate analyses confirms the existence of differences in the size and shape of cranial measurements among the valid species of Cerradomys: $C$. maracajuensis, $C$. marinhus, $C$. scotti, $C$. subflavus, $C$. vivoi, and Cerradomys langguthi. Regarding Cerradomys subflavus, $C$. vivoi, and $C$. langguthi, skull dimensions contributing significantly to this differentiation were related to the orbital region, auditory bulla, and cranial length and height. External measurements also separated the three species and, combined with skull dimensions, indicated a pattern in which C. subflavus is always larger and more robust than $C$. vivoi, whereas $C$. langguthi is consistently smaller.

Maximum-parsimony analysis clearly supported the monophyly of Cerradomys. This analysis also demonstrated the close relationship between $C$. maracajuensis and $C$. marinhus, and $C$. scotti as a sister branch with respect to the clade formed by $C$. subflavus, $C$. vivoi, and $C$. langguthi. This analysis also suggested that the ancestor of $C$. subflavus and Cerradomys vivoi was more recent than their common ancestor with $C$. langguthi.

Species of the genus Cerradomys inhabit open and drier biomes in South America, namely the Caatinga, Cerrado, and Chaco. Nevertheless, species of this genus are predominantly associated with the more mesic habitats of these biomes, such as gallery forests; humid forests formed by orographic rainfall, observed in hills and mountain ranges in the biome Caatinga (Mares et al., 1981), 


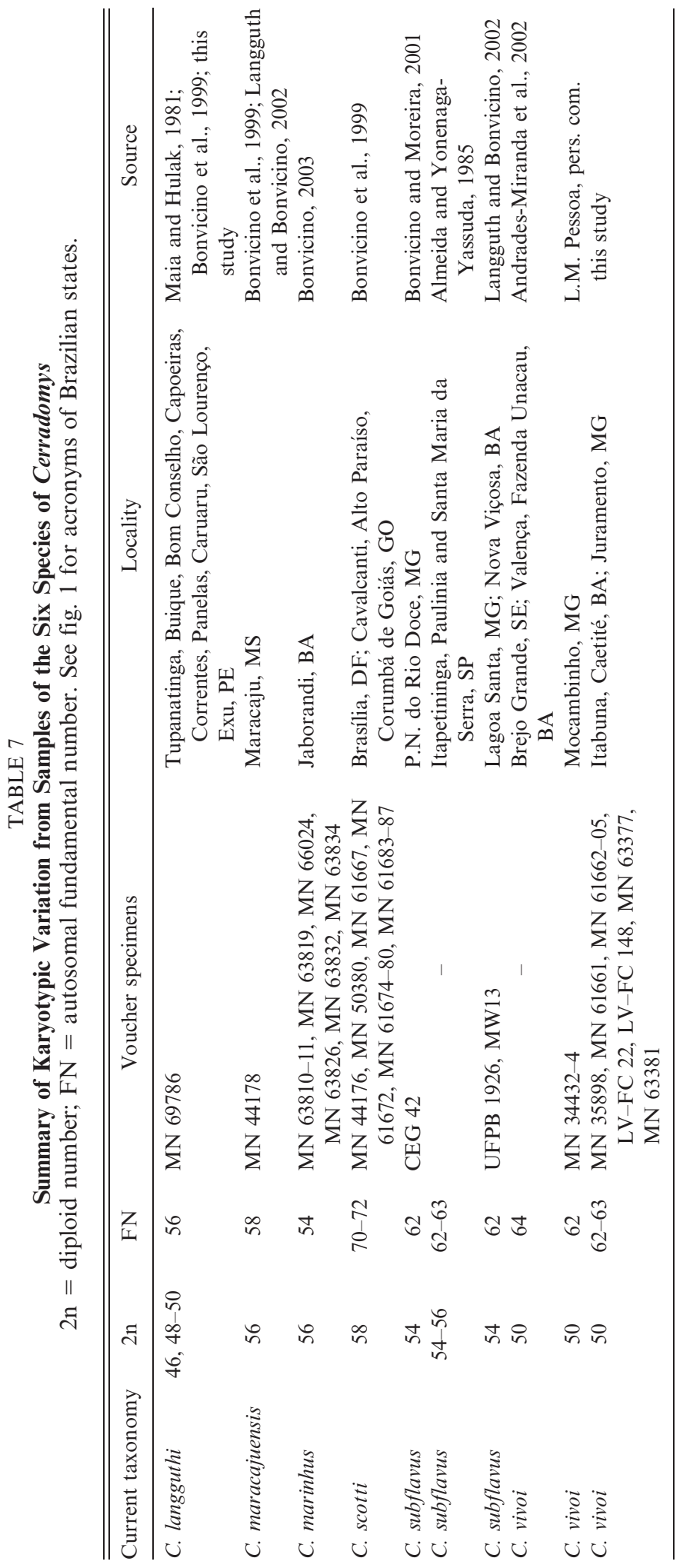


TABLE 8

Genetic Distance Estimates between Species of Cerradomys

\begin{tabular}{|c|c|c|c|c|c|c|c|c|c|}
\hline & Taxon & Number & 1 & 2 & 3 & 4 & 5 & 6 & 7 \\
\hline 1 & Cerradomys subflavus & LV-CEG 42 & & & & & & & \\
\hline 2 & C. vivoi & LV-FC 148 & 0.020 & & & & & & \\
\hline 3 & C. vivoi & MN 35898 & 0.017 & 0.003 & & & & & \\
\hline 4 & C. langguthi & MN 69786 & 0.046 & 0.057 & 0.057 & & & & \\
\hline 5 & C. scotti & MN 50379 & 0.085 & 0.084 & 0.085 & 0.087 & & & \\
\hline 6 & C. scotti & MN 61677 & 0.084 & 0.087 & 0.084 & 0.086 & 0.001 & & \\
\hline 7 & C. maracajuensis & MN 44178 & 0.122 & 0.122 & 0.119 & 0.127 & 0.112 & 0.111 & \\
\hline 8 & C. marinhus & MN 63824 & 0.119 & 0.113 & 0.110 & 0.122 & 0.107 & 0.106 & 0.092 \\
\hline
\end{tabular}

locally known as brejos de altitude; patches of more humid, closed canopy forest to drier, open-canopy woodland, locally known as cerradão (Eiten, 1972, 1992); and semideciduous forest. Exceptions to this pattern are the species that inhabit eastern Brazil: $C$. subflavus, C. vivoi, and C. langguthi. C. vivoi is a Caatinga-dwelling species that penetrates on Atlantic coastal rainforest in southern Bahia. The occurrence of $C$. vivoi in the latter habitat could be interpreted as a response to longterm, anthropic alteration of the habitat in this region (for example, extensive cacao plantations), since this species is found in low densities only in secondary and more open forest fragments, that occur marginally to more preserved fragments of Atlantic Forest (R. Pardini, unpublished data). A similar situation might be postulated for explaining the presence of Cerradomys langguthi (in this case, probably due to sugar-cane cultivation) and $C$. subflavus (probably due to extensive Eucalyptus plantations) in coastal Atlantic Forest in northeastern Brazil.

As the core species of the group in terms of geographic distribution (figs. 1, 2), C. scotti is

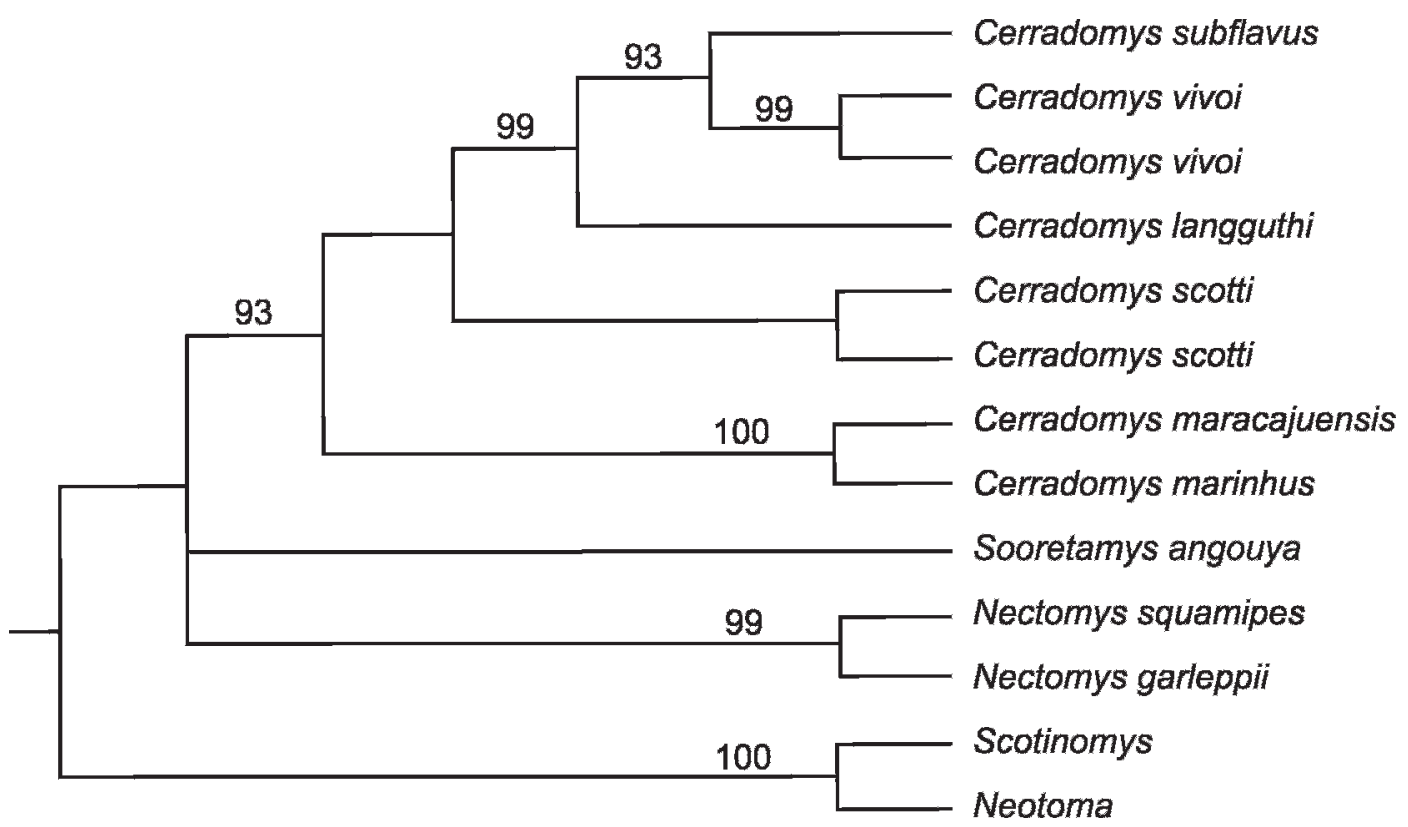

Fig. 14. Maximum-parsimony topology of the phylogenetic analysis of all known species of genus Cerradomys, employing DNA sequence data of the mitochondrial gene cytochrome $b$. Numbers near nodes represent bootstrap values obtained on the basis of 1,000 replicates. 
sympatric with almost all described species of the group: C. maracajuensis in Mato Grosso and Mato Grosso do Sul, Brazil, Sapucay, Paraguay, and Santa Cruz, Bolivia; C. marinhus, at the type locality of this species in Bahia; and samples of $C$. subflavus in Minas Gerais and São Paulo. However, there are some important differences among these species regarding habitat preferences in the Cerrado: C. scotti is associated more with the open vegetation of the Cerrado biome, namely the open and closed scrubs, both with scattered trees, locally known as campo cerrado and cerrado sensu stricto, respectively (Eiten, 1992), whereas C. maracajuensis and $C$. subflavus are associated more often with gallery forest and $C$. marinhus with grass marshes with buriti palms, called veredas (Eiten and Goodland, 1979), and flooded forests. At present, there is no evidence of sympatry between $C$. vivoi, C langguthi, and other congeneric forms: the known distributional records of the first species are restricted to the habitats of Caatinga and Atlantic Forest biomes south and east of the Rio São Francisco; the available collecting localities for the second species are distributed on the Caatinga and Atlantic Forest habitats north to the Rio São Francisco.

On the basis of the evidence herein presented, the evolutionary differentiation of the genus Cerradomys can be someway inferred. Species from eastern Brazil, C. subflavus, $C$. vivoi and $C$. langguthi, exhibit a clear trend of clinal variation, observed both in quantitative morphologic and karyologic traits. Samples of C. subflavus, the species with the southernmost distribution, present the largest dimensions in most external and cranial measurements, while samples of northernmost Cerradomys langguthi are characterized by the smallest values (table 2). Although some overlap is observed, average body and cranial dimensions diminish from south to north: geographic samples of $C$. subflavus are larger than those of $C$. vivoi, which are larger that those of $C$. langguthi. The same pattern of variation is observed regarding the diploid number (table 7), which decreases from south to north. In addition Cerradomys subflavus, C. vivoi, and C. langguthi also share a common ancestor. If this were accepted as indicative of sequence events since divergence, this clade is the most recent evolutionary branch of this group, a likely explanation for the striking morphologic resemblance among these species.

\section{ACKNOWLEDGMENTS}

We are grateful to the curators who granted us the permission to examine specimens under their care: Mario de Vivo (MZUSP); João Alves de Oliveira, Leandro Salles, and Luis Flamarion de Oliveira (MN); Alfredo Langguth (UFPB); Jader Marinho Filho (UnB); Gustavo Fonseca (UFMG); Carlos Galliari (MLP); Julieta Vargas (CBF); James L. Patton (MVZ); Bruce Patterson (FMNH); Phil Myers (UMMZ); Michael Carleton (USNM); Robert Voss (AMNH); and Paula Jenkins $(\mathrm{BMNH})$. We are also thankful to Ana Paula Carmignotto, Guillermo D'Elía, Louise Emmons, Marcelo Weksler, Yuri Leite, Leonora Costa, Raquel Moura, and Rui Cerqueíra for allowing examination of uncatalogued specimens. Alberto Barbosa de Carvalho, Eric Pedro Gonçalves, and Elisa Janowitzer provided valuable help with the photographs, and Fabio Machado helped organize data. We are most grateful to James Patton, Hussam Zaher, Michael Carleton, Guy Musser, and an anonymous reviewer: they provided valuable comments and suggestions on the manuscript. Hector Seuanez and Mary Knight provided insightful comments on the manuscript and also improved its style and grammar. This work is supported through grants from the American Museum of Natural History, the Field Museum, the Smithsonian Institution, the Museum of Comparative Zoology, Conselho Nacional de Pesquisa e Desenvolvimento-CNPq (grant numbers 309978/2003-3 and 477842/2004-6), and Fundação de Amparo à Pesquisa do Estado de São Paulo-FAPESP (auxílio a doutorado 98/12273-0, Programa Biota 98/05075-7 and auxílio a Jovem Pesquisador 01/0752-5).

\section{REFERENCES}

Alho, C.J.R., and O.M.M. Villela. 1984. Scansorial ability in Oryzomys eliurus and Oryzomys subflavus (Rodentia: Cricetidae) from the Cerrado. Revista Brasileira de Biologia 44: 403-408. 
Almeida, E.J.C., and Y. Yonenaga-Yassuda. 1985. Robertsonian fusion, pericentric inversion and sex chromosome heteromorphisms in Oryzomys subflavus (Cricetidae, Rodentia). Caryologia 38: 129-137.

Anderson, S. 1997. Mammals of Bolivia: taxonomy and distribution. Bulletin of the American Museum of Natural History 231: 1-652.

Andrades-Miranda, J., N.I.T. Zanchin, L.F. B Oliveira, A.R. Langguth, and M.S. Mattevi. 2002. (T2AG3)n telomeric sequence hybridization indicating centric fusion rearrangements in the karyotype of the rodent Oryzomys subflavus. Genetica 114: 11-16.

Bonvicino, C.R. 2003. A new species of Oryzomys (Rodentia, Sigmodontinae) of the subflavus group from the Cerrado of central Brazil. Mammalian Biology 68: 78-90.

Bonvicino, C.R., and M.A. Moreira. 2001. Molecular phylogeny of the genus Oryzomys (Rodentia: Sigmodontinae) based on cytochrome $b$ DNA sequences. Molecular Phylogenetics and Evolution 18: 282-292.

Bonvicino, C.R., I.B. Otazu, and P.M. Borodin. 1999. Chromosome variation in Oryzomys subflavus species group (Sigmodontinae, Rodentia) and its taxonomic implication. Cytologia 64: 327-332.

Brandt, R.S., and L.M. Pêssoa. 1994. Intrapopulational variability in cranial characters of Oryzomys subflavus (Wagner, 1842) (Rodentia: Cricetidae), in northeastern Brazil. Zoologischer Anzeiger 233: 45-55.

Brooks, D.M., R.J. Baker, R.J. Vargas, M., T. Tarifa, H. Aranibar, and J.M. Rojas. 2004. A new species of Oryzomys (Rodentia: Muridae) from an isolated pocket of Cerrado in eastern Bolivia. Museum of Texas Tech University Occasional Papers 241: 1-11.

Cabrera, A. 1961. Catalogo de los mamiferos de America del Sur. Revista del Museo Argentino de Ciencias Naturales Bernadino Rivadavia, Zoologia 4: 309-732.

Carleton, M.D. 1973. A survey of gross stomach morphology in new world Cricetinae (Rodentia, Muroidea), with comments on functional interpretations. University of Michigan, Museum of Zoology Miscellaneous Publications 146: 1-43.

Carleton, M.D., and G.G. Musser. 1989. Systematic studies of oryzomyine rodents (Muridae, Sigmodontinae): a synopsis of Microryzomys. Bulletin of the American Museum of Natural History 191: 1-83.

Costa, L.P. 2003. The historical bridge between the Amazon and Atlantic Forest of Brazil: a study of molecular phylogeography with small mammals. Journal of Biogeography 30: 71-86.
D’Elía, G., and U.F.J. Pardiñas. 2004. Systematics of Argentinean, Paraguayan, and Uruguayan swamp rats of the genus Scapteromys (Rodentia, Cricetidae, Sigmodontinae). Journal of Mammalogy 85: 897-910.

Eiten, G. 1972. The Cerrado vegetation of Brazil. Botanical Review 38: 201-341.

Eiten, G. 1992. Natural Brazilian vegetation types and their causes. Anais da Acadêmia Brasileira de Ciências 64: 35-65.

Eiten, G., and R. Goodland. 1979. Ecology and management of semi-arid ecosystems in Brazil. In B.H. Walker (editor), Management of semiarid ecosystems. Amsterdan: Elsevier, 277-300.

Emmons, L.H., V. Chávez, N. Rocha, B. Phillips, I. Phillips, F. del Aguila, and M.J. Swarner. 2006. The non-flying mammals of Parque Nacional Noel Kempff Mercado, Bolivia. Revista Boliviana de Ecología y Conservación Ambiental 19: 23-46.

Emmons, L.H., and J.L. Patton. 2005. A new species of Oryzomys (Rodentia: Muridae) from eastern Bolivia. American Museum Novitates 3478: 1-26.

Fonseca, G.A.B., and M.C.M. Kierulff. 1989. Biology and natural history of Brazilian Atlantic Forest small mammals. Bulletin of the Florida State Museum Biological Sciences 34: 99-152.

Goldman, E.A. 1918. The rice rats of North America (Genus Oryzomys). North American Fauna 43: 1-100.

Gonçalves, P.R., F.C. Almeida, and C.R. Bonvicino. 2005. A new species of Wiedomys (Rodentia: Sigmodontinae) from Brazilian Cerrado. Mammalian Biology: Zeitschrift für Saügetierkunde 70(1): 46-60.

Hershkovitz, P. 1962. Evolution of Neotropical cricetine rodents (Muridae) with special reference to the phyllotine group. Fieldiana Zoology 46: $1-524$.

Hingst, E., D. Astúa de Moraes, F.S. Rocha, L.C. Araripe, M. Weksler, and R. Cerqueira. 1997. Diversidade em uma comunidade de pequenos mamíferos de uma região de contato CaatingaCerrado. In L.L. Leite and C.H. Saito (editors), Contribuição ao conhecimento ecológico do Cerrado: trabalhos selecionados do III Congresso de Ecologia do Brasil. Brasília: Universidade de Brasília, 157-163.

Instituto Brasileiro de Geografia (IBG). 1969. Carta do Distrito Federal. 1:100.000.

Instituto Brasileiro de Geografia e Estatística (IBGE). 1970. Mapa do Estado da Paraíba (MEP). 1:500.000.

Instituto Brasileiro de Geografia e Estatística (IBGE). 1972. Carta do Brasil ao Milionésimo (CBM). 1:1.000.000. 
Karimi, Y., C.R. de Almeida, and F. Petter. 1976. Note sur les rongeurs du nord-est du Brésil. Mammalia 40: 257-266.

Kumar, S., K. Tamura, and M. Nei. 1993. MEGA: molecular evolutionary genetics analysis. Version 1.0. University Park: Pennsylvania State University.

Langguth, A. 1963. Las especies uruguayas del genero Oryzomys. Comunicaciones Zoologicas del Museo de Historia Natural de Montevideo 7: 1-19.

Langguth, A., and C.R. Bonvicino. 2002. The Oryzomys subflavus group, with description of two new species (Rodentia, Muridae, Sigmodontinae). Arquivos do Museu Nacional (Rio de Janeiro) 60: 285-294.

Lund, P.W. 1840. Blik paa Brasiliens Dyreverden för Sidste Jordomvaeltning. Anden Afhandling: Pattedyrene. Lagoa Santa D. 16 de Novbr. 1838. Kjöbenhavn: Trykt i Blanco Lunos Bogtrykkeri.

Maia, V., and A. Hulak. 1981. Robertsonian polymorphism in chromosomes of Oryzomys subflavus (Rodentia, Cricetidae). Cytogenetics and Cell Genetics 31: 33-39.

Mares, M.A., M.R. Willig, K.E. Streilein, and T.E. LacherJr.. 1981. The mammals of northeastern Brazil: a preliminary assessment. Annals of the Carnegie Museum of Natural History 50: 81-137.

Marinho-Filho, J.S., M.L. Reis, P.S. Oliveira, E.M. Vieira, and M.N. Paes. 1994. Diversity standards and small mammal numbers: conservation of the Cerrado biodiversity. Anais da Academia Brasileira de Ciências 66(Suppl. 1): 149-157

Musser, G.G., and M.D. Carleton. 2005. Superfamily Muroidea. In D.E. Wilson and D.A. Reeder (editors), Mammal species of the world: a taxonomic and geographic reference. 3rd ed. Baltimore: Johns Hopkins University Press, 894-1531.

Musser, G.G., M.D. Carleton, E. Brothers, and A.L. Gardner. 1998. Systematic studies of Oryzomyine rodents (Muridae, Sigmodontinae): diagnoses and distributions of species formerly assigned to Oryzomys "capito". Bulletin of the American Museum of Natural History 236: 1-376.

Musser, G.G., and M.M. Williams. 1985. Systematic studies of Oryzomyine rodents (Muridae): definition of Oryzomys villosus and Oryzomys talamancae. American Museum Novitates 2810: 1-22.

Neff, N.A., and L.F. Marcus. 1980. A survey of multivariate methods for systematics. Privately published for the workshop on Numerical Methods in Systematic Mammalogy at the annual meeting of the American Society of Mammalogists. New York: printed at the American Museum of Natural History, 243 pp.

Paiva, M.P. 1973. Distribuição e abundância de alguns mamíferos selvagens no estado do Ceará. Ciência e Cultura 25: 442-450.

Pardini, R. 2004. Effects of forest fragmentation on small mammals in an Atlantic Forest landscape. Biodiversity and Conservation 13: 2567-2586.

Patton, J.L., M.N.F. Da Silva, and J.R. Malcolm. 2000. Mammals of the Rio Juruá and the evolutionary and ecological diversification of Amazonia. Bulletin of the American Museum of Natural History 244: 1-306.

Paynter, R.A., Jr. 1992. Ornithological gazetteer of Bolivia. 2nd ed. Cambridge, MA: Bird Department, Museum of Comparative Zoology, Harvard University.

Paynter, R.A., Jr., and M.A. Traylor, Jr. 1991. Ornithological gazetteer of Brazil. Cambridge, MA: Bird Department, Museum of Comparative Zoology, Harvard University, 2 vols.

Percequillo, A.R. 1998. Sistemática de Oryzomys Baird, 1858 do Leste do Brasil (Muroidea, Sigmodontinae). Unpublished Master thesis, São Paulo: Universidade de São Paulo.

Percequillo, A.R. 2003. Sistemática de Oryzomys Baird, 1858: definição dos grupos de espécies e revisão taxonômica do grupo albigularis (Rodentia, Sigmodontinae). Unpublished PhD thesis, São Paulo: Universidade de São Paulo.

Percequillo, A.R., A.P. Carmignotto, and M.J.J. Silva. 2005. A new species of Neusticomys (Ichthyomyini, Sigmodontinae) from central Brazilian Amazonia. Journal of Mammalogy 86: 873-880.

Reig, C.A. 1977. A proposed unified nomenclature for the enamelled components of the molar teeth of the Cricetidae (Rodentia). Journal of Zoology (London) 181: 227-241.

Schinz, H. 1845. Systematisches Berzeichnik alter bis bekannten Säugethiere oder Synopsis Mammalium nach dem Cuvier'schen System. Solothurn: Verlag von Jent und Gassmann.

Seabright, M. 1971. A rapid banding technique for human chromosomes. Lancet 298(7731): 971972.

Sokal, R.R., and F.J. Rohlf. 1995. Biometry. New York: W.H. Freeman.

Stallings, J.R. 1989. Small mammals inventories in an eastern Brazilian park. Bulletin of the Florida State Museum Biological Sciences 34: 153-200.

Steppan, S.J. 1995. Revision of tribe Phyllotini (Rodentia: Sigmodontinae), with a phylogenetic hypothesis for the Sigmodontinae. Fieldiana Zoology New Series 80: 1-112. 
Streilein, K.E. 1982. Ecology of small mammals in the semiarid Brazilian Caatinga. I. Climate and faunal composition. Annals of the Carnegie Museum 51: 79-107.

Svartman, M., and E.J.C. de Almeida. 1992. Sex chromosomes polymorphisms in Oryzomys aff. subflavus (Cricetidae, Rodentia) from central Brazil. Caryoloia 45: 313-324.

Swofford, D.L. 2003. "PAUP*: phylogenetic analysis using parsimony (*and other methods), version 4. Sunderland, MA: Sinauer Associates.

Thomas, O. 1901. On mammals obtained by Mr. Alphonse Robert on the Rio Jordão, S.W. Minas Gerais. Annals and Magazine of Natural History ser. 7(8): 526-536.

United States Board on Geographical Names (USBGN). 1957. Gazetteer no. 35. Paraguay: official standard names. Washington, DC: Office of Geography, Department of the Interior.

United States Board on Geographical Names (USBGN). 1963. Gazetteer no. 71. Brazil: official standard names. Washington, DC: Office of Geography, Department of the Interior.

Vanzolini, P.E. 1992. A supplement to the ornithological gazetteer of Brazil. São Paulo: Museu de Zoologia, Universidade de São Paulo.

Voss, R.S. 1988. Systematics and ecology of Ichthyomyine rodents (Muroidea): patterns of morphological evolution in a small adaptive radiation. Bulletin of the American Museum of Natural History 188(2): 260-493.

Voss, R.S. 1993. A revision of the Brazilian muroid rodent genus Delomys, with remarks on "thomasomyine" characters. American Museum Novitates 3073: 1-44.

Voss, R.S., and M.D. Carleton. 1993. A new genus for Hesperomys molitor Winge and Holochilus magnus Hershkovitz (Mammalia, Muridae),

\section{APPENDIX 1}

\section{Gazetteer of Cerradomys Localities}

A list of the sampled localities of genus Cerradomys and their respective geographical coordinates are given below. Note that the numbers preceding collecting localities are the same presented in figures 1 and 2. For each locality we also provide the altitude, source for geographical coordinates, collector, collecting date, museum[s] or collection[s], and species obtained in each locality.

The gazetteer is arranged in alphabetical order, by country, state or province, and collecting locality. with an analysis of its phylogenetic relationships. American Museum Novitates 3085: 1-39.

Voss, R.S., D.P. Lunde, and N.B. Simmons. 2001. The Mammals of Paracou, French Guiana: a Neotropical lowland fauna. Part 2. Nonvolant species. Bulletin of the American Museum of Natural History 263: 1-236.

Voss, R.S., and L.F. Marcus. 1992. Morphological evolution in muroid rodents II. Craniometric factor divergence in seven Neotropical genera, with experimental results from Zygodontomys. Evolution 46: 1918-1934.

Wagner, J.A. 1842. Diagnosen neuer arten brasilischer Säugethiere. Archiv für Naturgeschichte Jahrgang 8(1): 356-362.

Weksler, M. 1996. Revisão sistemática do grupo de espécies nitidus do gênero Oryzomys (Rodentia: Sigmodontinae). Unpublished Master thesis, Rio de Janeiro: Universidade Federal do Rio de Janeiro.

Weksler, M. 2003. Phylogeny of Neotropical oryzomyine rodents (Muridae: Sigmodontinae) based on the nuclear IRBP exon. Molecular Phylogenetics and Evolution 29: 331-349.

Weksler, M. 2006. Phylogenetic relationships of Oryzomine rodents (Muroidea: Sigmodontinae): separate and combined analyses of morphological and molecular data. Bulletin of the American Museum of Natural History 296: $1-149$.

Weksler, M., A.R. Percequillo, and R.S. Voss. 2006. Ten new genera of Oryzomyine rodents (Cricetidae: Sigmodontinae). American Museum Novitates 3537: 1-29.

Winge, H. 1888. Jordfunde og nulevende Gnavere (Rodentia) fra Lagoa Santa, Minas Geraes, Brasilien: med udsigt over gnavernes indbyrdes slatskab. E Museo Lundii 1(3): 1-178 + 8 pls.

\section{BOLIVIA}

\section{BENI}

1. Boca del Rio Baures, $12^{\circ} 30^{\prime} \mathrm{S}, 64^{\circ} 18^{\prime} \mathrm{W}$ (collector). S. Anderson (col.), September, 1963. AMNH. C. maracajuensis.

2. Camino Vilches, $13^{\circ} 04^{\prime} \mathrm{S}, 64^{\circ} 48^{\prime} \mathrm{W}$ (Anderson, 1997). M. L. Kuns (col.), July, 1963. FMNH. C. maracajuensis.

3. Centenela, Rio Machupo, $1 \mathrm{~km}$ E of San Joaquin, $c a .13^{\circ} 04^{\prime} \mathrm{S}, 64^{\circ} 48^{\prime} \mathrm{W}$ (collector); ca. 200m (Paynter, 1992). M.L. Kuns (col.), September, 1963. FMNH. C. maracajuensis.

4. Pampa de Meio, $12^{\circ} 30^{\prime} \mathrm{S}, 64^{\circ} 15^{\prime} \mathrm{W}$ (collector). S. Anderson (col.), September, 1964. AMNH. C. maracajuensis. 
5. Puerto Almacen, $14^{\circ} 47^{\prime} \mathrm{S}, 64^{\circ} 51^{\prime} \mathrm{W} ; 230 \mathrm{~m}$ (collector). S. Anderson (col.), Augut, 1983. AMNH. C. maracajuensis.

6. Rio Beni, Magdalena, $13^{\circ} 20^{\prime} \mathrm{S}, 64^{\circ} 08^{\prime} \mathrm{W} ; 776 \mathrm{~m}$ (Paynter, 1992). M.L. Kuns (col.), July, 1963; June, 1964. FMNH. C. maracajuensis.

7. Rio Itenez [ $=$ Rio Guapore], opposite Costa Marques, $12^{\circ} 29^{\prime} \mathrm{S}, \quad 64^{\circ} 17^{\prime} \mathrm{W}$ (collector). A. Ximenes (col.), September, 1964. AMNH. C. maracajuensis.

8. Rio Mamoré, en la boca del Rio Ibare, $14^{\circ} 37^{\prime} \mathrm{S}$, $64^{\circ} 57^{\prime} \mathrm{W}$ (collector). D. E Anez (col.), September, 1965. AMNH. C. maracajuensis.

9. Rio Mamoré, Puerto Caballo, $13^{\circ} 43^{\prime} \mathrm{S}, 65^{\circ} 21^{\prime} \mathrm{W}$ (collector). S. Anderson. (col.), O. Eduardo (col.), September, 1965. AMNH. C. maracajuensis.

10. Rio Mamoré, circa $10 \mathrm{~km} \mathrm{~W}$ San Pedro, $14^{\circ} 20^{\prime} \mathrm{S}, \quad 64^{\circ} 55^{\prime} \mathrm{W}$. S. Anderson (col.), September, 1965. AMNH. C. maracajuensis.

11. Rio Mamoré, circa $23 \mathrm{~km}$ W San Javier, $14^{\circ} 34^{\prime} \mathrm{S}, \quad 64^{\circ} 42^{\prime} \mathrm{W}$ (collector). S. Anderson (col.), September, 1965. AMNH. C. maracajuensis.

12. San Joaquin, $13^{\circ} 04^{\prime} \mathrm{S}, 64^{\circ} 49^{\prime} \mathrm{W}$; ca. $200 \mathrm{~m}$ (Paynter, 1992). M.L. Kuns (col.), MarchApril, June-July, August-October, December, 1963; January, March, May-June, 1964; FMNH. USNM. C. maracajuensis.

\section{LA PAZ}

13. Pitiguaya [= La Florida; see Paynter, 1992], $16^{\circ} 21^{\prime} \mathrm{S}, 67^{\circ} 46^{\prime} \mathrm{W} ; 5800 \mathrm{ft}$ [= 1750m] (Paynter, 1992). G.H.H. Tate (col.), May, 1926. AMNH. C. maracajuensis.

-. Rio Beni, not located (see Anderson, 1997). I. Mercado T. (col.), September, 1985. AMNH. C. maracajuensis.

\section{Santa Cruz}

14. $1 \mathrm{~km}$ NE Estancia Las Cuevas, $18^{\circ} 11^{\prime} \mathrm{S}$, $63^{\circ} 44^{\prime} \mathrm{W}$; $1300 \mathrm{~m}$ (collector). J.L. Dunnum (col.), May, 1991. AMNH. C. maracajuensis.

15. $3 \mathrm{~km} \mathrm{SE}$ of Montero, $17^{\circ} 23^{\prime} \mathrm{S}, 63^{\circ} 14^{\prime} \mathrm{W} ; 250 \mathrm{~m}$ (collector). I. Mercado T. (col.), August, 1985. AMNH. C. maracajuensis.

16. $3.5 \mathrm{~km} \mathrm{~W}$ of Estacion Pailon, $17^{\circ} 39^{\prime} \mathrm{S}$, $62^{\circ} 47^{\prime} \mathrm{W} ; 300 \mathrm{~m}$ (collector). S. Anderson (col.), September, 1984. AMNH. C. maracajuensis.
17. $6 \mathrm{~km} \mathrm{~N}$ of Buen Retiro, $17^{\circ} 13^{\prime} \mathrm{S}, 63^{\circ} 38^{\prime} \mathrm{W}$; $300 \mathrm{~m}$ (collector). S. Anderson (col.), J.A. Cook (col.), September, 1984. AMNH. C. maracajuensis.

18. $6 \mathrm{~km}$ by road, $\mathrm{W}$ of Ascencion, $15^{\circ} 43^{\prime} \mathrm{S}$, $63^{\circ} 04^{\prime} \mathrm{W} ; 240 \mathrm{~m}$ (collector). S. Anderson (col.). AMNH. C. maracajuensis.

19. $7 \mathrm{~km} \mathrm{~N}, 17 \mathrm{~km} \mathrm{~W}$ Buena Vista, $17^{\circ} 24^{\prime} \mathrm{S}$, $63^{\circ} 44^{\prime} \mathrm{W} ; 353 \mathrm{~m}$ (collector). ' $\mathrm{km} 119$ on Carretera Ayapacani, Propriedad Nuevo Mundo. Habitat, dense shrub grass field (cleared forest), dense forest adjacent" (collector). G. Schmitt (col.), December, 1978. AMNH. C. maracajuensis.

20. $12 \mathrm{~km} \mathrm{~S}, 8 \mathrm{~km} \mathrm{E}$ of Santa Cruz, $17^{\circ} 55^{\prime} \mathrm{S}$, $63^{\circ} 10^{\prime} \mathrm{W}$ (Anderson, 1997). S. Anderson (col.), August, 1983. AMNH. C. marajuensis.

21. $15 \mathrm{~km} \mathrm{~S}$ of Santa Cruz, $17^{\circ} 53^{\prime} \mathrm{S}, 63^{\circ} 07^{\prime} \mathrm{W}$; $430 \mathrm{~m}$ (collector). Romer S. Miserendino S. (col.), June, 1991. AMNH. C. maracajuensis.

22. Ayacucho, $17^{\circ} 00^{\prime} \mathrm{S}, 63^{\circ} 55^{\prime} \mathrm{W} ; 250 \mathrm{~m}$ (collector) [includes Ibanez, Ayacucho]. S. Anderson (col.), October, 1987. AMNH. USNM. C. maracajuensis.

23. Buena Vista, $17^{\circ} 27^{\prime} \mathrm{S}, 63^{\circ} 40^{\prime} \mathrm{W}$ (Paynter); $450 \mathrm{~m}$ (collector). F. Steinbach (col.), May, 1926 [FMNH]; July-August, November, 1926 [BMNH]. C. maracajuensis.

24. Cordillera, Basilio, not located; the geographical coordinates of Basilio are $18^{\circ} 08^{\prime} \mathrm{S}$, $63^{\circ} 19^{\prime} \mathrm{W} ; 703$ m. USNM. C. maracajuensis.

25. El Refugio Pampa, $3 \mathrm{~km}$ NE from camp, $14^{\circ} 75^{\prime} \mathrm{S}, 61^{\circ} 01^{\prime} \mathrm{W}$ (collector). "In deep grass and shrubs pampa" (collector). I.G. Phillips (col.), L.H. Emmons (col.), N. Rocha (col.), October-November, 1998. USNM. C. maracajuensis, C. scotti.

26. Estancia Cachuela Esperanza, $16^{\circ} 47 \mathrm{~S}, 63^{\circ} 23 \mathrm{~W}$ (collector). N. Olds, S. Anderson (cols.), August, 1984. AMNH. C. maracajuensis.

27. Pozo Mario, Estancia Las Conchas, $17^{\circ} 35^{\prime} \mathrm{S}$, $59^{\circ} 30^{\prime} \mathrm{W}, 220 \mathrm{~m}$ (collector); type locality of Cerradomys andersoni. J. Vargas-M. (col.), April, 1999. CBF. C. scotti.

28. Rio Palomitillas [=Palometillas], Buena Vista, $16^{\circ} 36^{\prime} \mathrm{S}, 6^{\circ} 18^{\prime} \mathrm{W}$ (Paynter, 1992); $400 \mathrm{~m}$ (collector). F. Steinbach (col.), December, 1926. BMNH. C. maracajuensis. 
29. San Miguel Rincon, $17^{\circ} 23^{\prime} \mathrm{S}, 63^{\circ} 32^{\prime} \mathrm{W} ; 300 \mathrm{~m}$ (collector). N. Olds (col.), S. Anderson (col.), August, 1984. AMNH. C. maracajuensis.

30. San Rafael de Amboro, $17^{\circ} 36^{\prime} \mathrm{S}, 63^{\circ} 36^{\prime} \mathrm{W}$; $400 \mathrm{~m}$ (collector). I. Mercado T. (col.), Agosto, 1985. AMNH. C. maracajuensis.

31. Santa Rosa de la Roca, $15^{\circ} 50^{\prime} \mathrm{S}, 61^{\circ} 27^{\prime} \mathrm{W}$; $250 \mathrm{~m}$ (collector). S. Anderson (col.), June, 1990. AMNH. C. scotti.

32. Warnes, $17^{\circ} 30^{\prime} \mathrm{S}, 63^{\circ} 10^{\prime} \mathrm{W} ; 275 \mathrm{~m}$ (Paynter, 1992). USNM. C. maracajuensis.

\section{BRAZIL}

\section{BAHIA}

33. Andaraí, $12^{\circ} 48^{\prime} \mathrm{S}, 41^{\circ} 20^{\prime} \mathrm{W}$ (USBGN, 1963). M.T.U. Rodrigues (col.) UFPB. C. vivoi.

34. Caetité, $14^{\circ} 04^{\prime} \mathrm{S}, 42^{\circ} 29^{\prime} \mathrm{W}$. P.S. D’Andrea (col.). MN. C. vivoi.

35. Fazenda Bolandeira, $10 \mathrm{~km} \mathrm{~S}$ Una, Una, $15^{\circ} 21^{\prime} \mathrm{S}, 39^{\circ} 00^{\prime} \mathrm{W}$ (collector). L.P. Costa, R. Moura, Y. Leite (cols.), August, 1996. UFMG. C. vivoi.

36. Fazenda Lagoa D’Água, Conceição do Coité, Serrinha, Feira de Santana, not located. Here are employed the geographical coordinates of Conceição do Coité, $11^{\circ} 33^{\prime} \mathrm{S}, \quad 39^{\circ} 16^{\prime} \mathrm{W}$ (USBGN, 1963). M. Rampand (col.), August, 1986. BMNH. C. vivoi.

37. Fazenda Massapê, $15 \mathrm{~km}$ SW Serrinha, Serrinha, $11^{\circ} 43^{\prime} \mathrm{S}, \quad 39^{\circ} 05^{\prime} \mathrm{W}$ (collector). Y. Leite (col.), May, 1998. UFMG. C. vivoi.

38. Fazenda Santa Rita, 8 km E Andaraí, Andaraí, $12^{\circ} 48^{\prime} 06^{\prime \prime} \mathrm{S}, 41^{\circ} 05^{\prime} 41^{\prime \prime} \mathrm{W}$; 399m (collector). L.P. Costa (col.), may, 1998. UFMG. C. vivoi.

39. Fazenda Sertão do Formoso, (formerly known as Fazenda Jucurutu), Jaborandi, $14^{\circ} 48^{\prime} \mathrm{S}$, $45^{\circ} 57^{\prime} \mathrm{W}$; $775 \mathrm{~m}$ (collector); type locality of $C$. marinhus. See further explanations under the heading Type Locality of C. marinhus. C.R. Bonvicino, S.M. Lindbergh, P.S. D'Andrea, L.S. Maroja, and A. Bezerra (cols.), September, 1998. MN. C. marinhus, C. scotti.

40. Gandú, $13^{\circ} 44^{\prime} 38^{\prime \prime} \mathrm{S}, \quad 39^{\circ} 29^{\prime} 12^{\prime \prime} \mathrm{W}$ (USBGN, 1963). UnB. C. vivoi.

41. Lagoa de Itaparica, $11^{\circ} 03^{\prime} \mathrm{S}, \quad 42^{\circ} 47^{\prime} \mathrm{W}$ (USBGN, 1963). P.L.B. Rocha (col.). MZUSP. C. vivoi.
42. Mirorós, $11^{\circ} 26^{\prime} \mathrm{S}, 42^{\circ} 19^{\prime} \mathrm{W}$ (USBGN, 1963). UnB. C. vivoi.

43. Mucujê, $13^{\circ} 00^{\prime} \mathrm{S}, 41^{\circ} 23^{\prime} \mathrm{W}$ (USBGN, 1963). MZUSP. C. vivoi.

44. Nova Viçosa, $17^{\circ} 53^{\prime} \mathrm{S}, 39^{\circ} 22^{\prime} \mathrm{W}$ (USBGN, 1963). M. Weksler (col.). LV. C. subflavus.

45. Parque Zoobotânico da Comissão Executiva do Plano de Lavoura Cacaueira (CEPLAC), $6 \mathrm{~km}$ E de Itabuna por estrada, Itabuna, $14^{\circ} 48^{\prime} \mathrm{S}, 39^{\circ} 20^{\prime} \mathrm{W}$ (collector); type locality of C. vivoi. E.H. Zaher and M. Lara (cols.), December, 1992. MN. C. vivoi.

46. Reserva Biológica de Una, $15^{\circ} 10^{\prime} \mathrm{S}, 39^{\circ} 03^{\prime} \mathrm{W}$ (collector). R. Pardini (col.), September, 1999, January, 2000. MZUSP. C. vivoi.

47. Rio Unamirim, $14 \mathrm{~km} \mathrm{~W}$ de Valença, Valença, $13^{\circ} 17^{\prime} \mathrm{S}, 39^{\circ} 13^{\prime} \mathrm{W}$ (collector). O.S. Farias (col.), August, 1985. UFPB. C. vivoi.

48. Sebastião Laranjeiras (Estreito IV), $14^{\circ} 34^{\prime} 23^{\prime \prime} \mathrm{S}$, $42^{\circ} 56^{\prime} 25^{\prime \prime} \mathrm{W}$ (collector). UnB. C. vivoi.

49. Una, $15^{\circ} 17^{\prime} \mathrm{S}, 39^{\circ} 04^{\prime} \mathrm{W}$ (USBGN, 1963). M. Sábato (col.). UFMG. C. vivoi.

\section{Ceará}

50. Guaribas, $5 \mathrm{~km}$ NW Crato, Crato, ca. $7^{\circ} 13^{\prime} \mathrm{S}$, $39^{\circ} 27^{\prime} \mathrm{W}$ (collector). L.P. Costa (col.), May, 1998. UFMG. C. langguthi.

51. Sítio Friburgo, grota do cafezal, a cerca de $1 \mathrm{~km}$ da sede, Serra de Baturité, Pacoti, $04^{\circ} 13^{\prime} 01^{\prime \prime} \mathrm{S}, \quad 38^{\circ} 53^{\prime} 53^{\prime \prime} \mathrm{W}$ (collector). A.R. Percequillo (col.), October, 1998. MZUSP. C. langguthi.

52. Sítio Friburgo, morro em frente à sede, Serra de Baturité, Pacoti, 04 $13^{\prime} 48^{\prime \prime} \mathrm{S}, 38^{\circ} 54^{\prime} 29^{\prime \prime} \mathrm{W}$ (collector). A.R. Percequillo (col.), October, 1998. MZUSP. C. langguthi.

53. Sítio Páscoa, $5 \mathrm{~km} \mathrm{NW}$ Crato, Crato, ca. $7^{\circ} 13^{\prime} \mathrm{S}, 39^{\circ} 27^{\prime} \mathrm{W}$ (collector). L.P. Costa (col.), May, 1998. UFMG. C. langguthi.

\section{Distrito Federal (DF)}

54. Fazenda Água Limpa, $15^{\circ} 57^{\prime} \mathrm{S}, \quad 47^{\circ} 56^{\prime} \mathrm{W}$ (Paynter and Traylor, 1991). O. Villela (col.), outubro de 1981. UnB, UFPB. C. scotti.

55. Parque Nacional de Brasília, $15^{\circ} 40^{\prime} \mathrm{S}, 48^{\circ} 00^{\prime} \mathrm{W}$ (CDF; IBG, 1969) [includes Brasília]. A. C. Santos (col.), June-August, 1970. Antônio and 
Luiz (cols.), December, 1980; April, 1981. José Carlos and Luiz (cols.), April, June, 1981. Alba (col.?), May, 1981. UnB, FMNH. C. scotti.

56. Reserva Biológica de Águas Emendadas, $15^{\circ} 33^{\prime} \mathrm{S}, 47^{\circ} 37^{\prime} \mathrm{W}$ (CDF; IBG, 1969). M.L. Reis (col.), May-September, November-December, 1987; January-May, October, 1988. E.M. Vieira (col.), February, 1989. UnB. C. scotti.

57. Reserva Ecológica Roncador, IBGE, $15^{\circ} 57^{\prime} \mathrm{S}$, $47^{\circ} 52^{\prime} \mathrm{W}$ (CDF; IBG, 1969). K. Redford (col.), February, April and October, 1981. P.S. Oliveira (col.), July-August, 1991. UnB e MPEG. C. scotti.

\section{GoIÁs}

58. $3 \mathrm{~km}$ leste de Mambai, $14^{\circ} 29^{\prime} \mathrm{S}, 46^{\circ} 08^{\prime} \mathrm{W}$ (CBM; IBGE, 1972). C. A. Caetano (col.), junho de 1990. UFPB. C. scotti.

59. $5 \mathrm{~km} \mathrm{~N}$ Alto Paraíso, Alto Paraíso, $14^{\circ} 05^{\prime} \mathrm{S}$, $47^{\circ} 31^{\prime} \mathrm{W}$ (collector). C.R. Bonvicino (col.). MN. C. scotti.

60. $14 \mathrm{~km} \mathrm{~N}$ Alto Paraíso, Alto Paraíso, $14^{\circ} 01^{\prime} \mathrm{S}$, $47^{\circ} 32^{\prime} \mathrm{W}$ (collector). C.R. Bonvicino (col.). C. scotti.

61. Anápolis, $16^{\circ} 19^{\prime} \mathrm{S}, 48^{\circ} 58^{\prime} \mathrm{W}$ (CBM; IBGE, 1972). C. Lako (col.), R.M. Gilmore (col.), M.E.S.-Serviço de Estudos e Pesquisas sobre a Febre Amarela (SEPFA)/The Rockfeller Foundation-Internation Division Health, January-March; June-July, September, 1937. AMNH, MN. C. subflavus.

62. Cerrado Alto, Catalão, not located. Here are employed the geographical coordinates of Catalão, $18^{\circ} 10^{\prime} \mathrm{S}, 47^{\circ} 57^{\prime} \mathrm{W}$ (USBGN, 1963). L.P.S. Pinto (col.), June, 1988. UFMG. C. scotti.

63. Fazenda Bandeirantes, Rio Lageado, Baliza, not located. Here are employed the geographical coordinates of Baliza $16^{\circ} 15^{\prime} \mathrm{W}, 52^{\circ} 25^{\prime} \mathrm{W}$ (USBGN, 1963). C.R. Bonvicino (col.), July, October, 1988. UnB. C. scotti.

64. Fazenda Fiandeira, Parque Nacional de Chapada dos Veadeiros, $65 \mathrm{~km}$ SSW de Cavalcante, $14^{\circ} 19^{\prime} \mathrm{S}, 47^{\circ} 45^{\prime} \mathrm{W}$ (CBM; IBGE, 1972). C.R. Bonvicino, S. Lindbergh, M. Weksler and B. Lemos (cols.). MN. C. scotti.

65. Morro dos Cabeludos, Corumbá de Goiás, $15^{\circ} 54^{\prime} \mathrm{S}, 48^{\circ} 48^{\prime} \mathrm{W}$ (collector); type locality of Cerradomys scotti. S.M. Lindbergh (col.), September, 1991. MN. C. scotti.

\section{Maranhão}

66. Alto Parnahyba (= Alto Parnaíba), 400-600m, $09^{\circ} 06^{\prime} \mathrm{S}, 45^{\circ} 57^{\prime} \mathrm{W}$ (USBGN, 1963); 400-600 m. E. Snethlage (col.), August, 1925. FMNH. C. langguthi.

67. Estiva, Município Alto Parnaíba, $9^{\circ} 16^{\prime} \mathrm{S}$, $46^{\circ} 35^{\prime} \mathrm{W}$ (USBGN, 1963). MPEG. C. scotti.

68. Fazenda Lagoa Nova, Município Bacabal, not located. Here are employed the geographical coordinates of Bacabal, $04^{\circ} 14^{\prime} \mathrm{S}, \quad 44^{\circ} 47^{\prime} \mathrm{W}$ (USBGN, 1963). MPEG. C. langguthi.

\section{Mato Grosso}

69. $264 \mathrm{~km} \mathrm{~N}$ Xavantina, Serra do Roncador, $400 \mathrm{~m}, \quad 12^{\circ} 49^{\prime} \mathrm{S}, \quad 51^{\circ} 46^{\prime} \mathrm{W}$ (Musser et al., 1998). I.R. Bishop (col.), August, October, 1968 BMNH. C. maracajuensis, C. scotti.

70. Escola Evangélica Buriti, Chapada dos Guimarães, not located. Accordingly to the curator of UFMT mammal collection (M. Shiraiwa), this is an Evangelic School situated near the town of Chapada dos Guimarães, located at $15^{\circ} 26^{\prime} \mathrm{S}, 55^{\circ} 45^{\prime} \mathrm{W}$ (USBGN, 1963). J. Dalponte (col.). UFMT. C. scotti.

71. Estação Ecológica Serra das Araras, $65 \mathrm{~km} \mathrm{~S}$ de Barra do Bugres, Barra do Bugres, $15^{\circ} 39^{\prime} \mathrm{S}$, $57^{\circ} 13^{\prime} \mathrm{W}$ (Paynter and Traylor, 1991). J. Dalponte (col.). UFMT. C. scotti.

72. Fazenda Altamira, Ponte Branca, not located. Here are employed the geographical coordinates of Ponte Branca, $16^{\circ} 43^{\prime} \mathrm{S}, 52^{\circ} 47^{\prime} \mathrm{W}$ (CBM; IBGE, 1972). C.R. Bonvicino (col.), July, 1988. UnB. C. scotti.

73. Usina Hidroelétrica de Manso, $100 \mathrm{~km} \mathrm{~N}$ de Cuiabá, $14^{\circ} 42^{\prime} \mathrm{S}, 56^{\circ} 02^{\prime} \mathrm{W}$ (CBM; IBGE, 1972). T.E. Lacher, Jr. (col.), October, 1988. UnB. C. scotti.

74. Usina Hidroelétrica de Manso, Rio Manso, Chapada dos Guimarães, $14^{\circ} 52^{\prime} \mathrm{S}, 55^{\circ} 57^{\prime} \mathrm{W}$ (Marinho-Filho et al., 1994). C. Alho and J. Marinho-Filho (cols.), May, 1988. E.M. Vieira (col.), February, 1988; February, 1989. M.L. Reis (col.), June-July, September, 1988; February, 1989. P.S. Oliveira (col.), February, 1989. UnB. C. scotti.

\section{Mato Grosso do Sul}

75. Fazenda da Mata, Maracaju, $21^{\circ} 38^{\prime} \mathrm{S}, 55^{\circ} 09^{\prime} \mathrm{W}$ (Langguth and Bonvicino, 2002); type locality of C. maracajuensis. C.R. Bonvicino and E.D. 
Hingst (cols.), July, 1992. MN. C. maracajuensis.

76. Fazenda Primavera, Bataiporã, not located. Here are employed the geographical coordinates of Bataiporã, $22^{\circ} 20^{\prime} \mathrm{S}, \quad 53^{\circ} 17^{\prime} \mathrm{W}$ (USBGN, 1963). L. E. Pereira (col.), fevereiro de 1993. MZUSP. C. maracajuensis.

77. Maracaju, $21^{\circ} 38^{\prime} \mathrm{S}, 55^{\circ} 09^{\prime} \mathrm{W}$ (USBGN, 1963); $500 \mathrm{~m}$ (collector). R.M. Gilmore (col.), M.E.S.-Serviço de Estudos e Pesquisas sobre a Febre Amarela (SEPFA)/The Rockfeller Foundation-Internation Division Health; March-July, 1937. AMNH, MN. C. maracajuensis, C. scotti.

\section{Minas Gerais}

78. Águas Claras, Ravena (= Águas Claras, km 28, Ravena). Not located; here are employed the geographical coordinates of Ravena, $19^{\circ} 47^{\prime} \mathrm{S}$, $43^{\circ} 45^{\prime} \mathrm{W}$ (USBGN, 1963). C.A. [Unknown acronym] (col.), October, 1979. UFMG. C. subflavus.

79. [Área 23,] Usina Hidroelétrica de Miranda, Uberlândia, $19^{\circ} 05^{\prime} \mathrm{S}, 47^{\circ} 56^{\prime} \mathrm{W}$; $710 \mathrm{~m}$ (collector). L.P. Costa (col.), August, 1998. UFMG. C. scotti.

80. BR 262, km 580, Ibiá, not located. Here are employed the geographical coordinates of Ibiá, $19^{\circ} 29^{\prime} \mathrm{S}, 46^{\circ} 32^{\prime} \mathrm{W}$ (CBM; IBGE, 1972). M.L. Reis (col.), E.M. Vieira (col.), January, 1989. UnB. C. subflavus.

81. BR 262, km 609, Campos Altos, not located. Here are employed the geographical coordinates of Campos Altos, $19^{\circ} 42^{\prime} \mathrm{S}, 46^{\circ} 10^{\prime} \mathrm{W}$ (CBM; IBGE, 1972). M.L. Reis (col.), January, 1989. UnB. C. subflavus.

82. Campus Ecológico da UFMG, Belo Horizonte, $19^{\circ} 55^{\prime} \mathrm{S}, 43^{\circ} 56^{\prime} \mathrm{W}$ (USBGN, 1963). C.A.M.P. [Unknown acronym] (col.), October, 1980. UFMG. C. subflavus.

83. Caqui, Barra Longa, not located. Here are employed the geographical coordinates of Barra Longa, $20^{\circ} 17^{\prime} \mathrm{S}, 43^{\circ} 02^{\prime} \mathrm{W}$ (USBGN, 1963). J.B. Varejão (col.), April, 1979. UFMG. C. subflavus.

84. Cerrado de Indianópolis, Indianópolis, not located. Here are employed the geographical coordinates of Indianópolis, $19^{\circ} 02^{\prime} \mathrm{S}, 47^{\circ} 55^{\prime} \mathrm{W}$ (USBGN, 1963). G. Herrman (col.), October, 1987. UFMG. C. scotti.

85. Cerrado Fazenda Boa, BR 452, km 169, margem esquerda do Rio Araguari, not locat- ed. Here are employed the geographical coordinates of Indianópolis, $19^{\circ} 02^{\prime} \mathrm{S}, 47^{\circ} 55^{\prime} \mathrm{W}$ (UFMG database). G. Hermann (col.), October, 1987. UFMG. C. scotti.

86. Cerrado João Alonso, Perdizes, not located. Here are employed the geographical coordinates of Perdizes, $19^{\circ} 21^{\prime} \mathrm{S}, 47^{\circ} 17^{\prime} \mathrm{W}$ (USBGN, 1963) [includes Mata de galeria João Alonso, Perdizes]. UFMG. C. scotti.

87. COPASA-Área de Proteção Ambiental, Serra Azul, Mateus Leme, not located. Here are employed the geographical coordinates of Serra Azul, 20 $04^{\prime} \mathrm{S}, 44^{\circ} 26^{\prime} \mathrm{W}$ (USBGN, 1963). April-May, 1986. UFMG. C. scotti, C. subflavus.

88. Coromandel, $18^{\circ} 28^{\prime} \mathrm{S}, 47^{\circ} 13^{\prime} \mathrm{W}$ (USBGN, 1963) [includes Cerrado do Gato Mourisco; Fazenda da Barra; Fazenda Marques; Mata da Abadia, ponte sobre o Rio Parnaíba; em Coromandel]. L.P.S. Pinto (col.), February, May, 1988. February, 1988. UFMG. C. subflavus, C. scotti.

89. EMBRAPA, Sete Lagoas, not located. Here are employed the geographical coordinates of Sete Lagoas, $19^{\circ} 27^{\prime} \mathrm{S}, 44^{\circ} 14^{\prime} \mathrm{W}$ (USBGN, 1963). C. Valle (col.), April, 1978. Severino (col.), May-June, 1979. UFMG. C. subflavus.

90. Estação de Pesquisa e Desenvolvimento Ambiental de PETI (Estação da CEMIG), Santa Barbara, $19^{\circ} 23^{\prime} \mathrm{S}, \quad 43^{\circ} 21^{\prime} \mathrm{W}$ (CBM; IBGE, 1972). November, 1986; January, 1987. UFMG. C. subflavus.

91. Fazenda Baroneza, Santa Luzia, not located. Here are employed the geographical coordinates of Santa Luzia, $19^{\circ} 47^{\prime} \mathrm{S}, 43^{\circ} 52^{\prime} \mathrm{W}$ (USBGN, 1963). Severino (col.), setembro de 1978. UFMG. C. subflavus.

92. Fazenda Barreiro Grande, Pompeu, not located. Here are employed the geographical coordinates of Pompeu, $19^{\circ} 12^{\prime} \mathrm{S}, \quad 44^{\circ} 59^{\prime} \mathrm{W}$ (USBGN, 1963). C. Pinto and C. Valle (cols.), January, 1979. UFMG. C. subflavus.

93. Fazenda Canoas, $36 \mathrm{~km} \mathrm{NE}, 12 \mathrm{~km}$ W Montes Claros (by road), Juramento, not located. Here are employed the geographical coordinates of Juramento, $16^{\circ} 50^{\prime} \mathrm{S}, 43^{\circ} 35^{\prime} \mathrm{W}$ (USBGN, 1963). Labvert (col.). MN. C. vivoi.

94. Fazenda Capão Grande, Santa Juliana, not located. Here are employed the geographical coordinates of Santa Juliana, $19^{\circ} 19^{\prime} \mathrm{S}, 47^{\circ} 32^{\prime} \mathrm{W}$ 
(USBGN, 1963). G. Herrman (col.), February, 1988. UFMG. C. scotti.

95. Fazenda Cavaia, $17 \mathrm{~km} \mathrm{~N} \mathrm{e} 11 \mathrm{~km} \mathrm{~W}$ de Lagoa Santa, $19^{\circ} 28^{\prime} \mathrm{S}, 43^{\circ} 57^{\prime} \mathrm{W}$ (CBM; IBGE, 1972). A. Langguth (col.), dezembro de 1988. UFPB. C. subflavus.

96. Fazenda EPAMIG, Governador Valadares, not located. Here are employed the geographical coordinates of Governador Valadares, $18^{\circ} 51^{\prime} \mathrm{S}, 41^{\circ} 56^{\prime} \mathrm{W}$ (USBGN, 1963). Severino (col.), October-November, 1978. UFMG. C. subflavus.

97. Fazenda Esmeralda, Rio Casca, not located. Here are employed the geographical coordinates of Rio Casca, a municipality of Minas Gerais [and not the Rio Casca, a right bank tributary of Rio Doce], $20^{\circ} 13^{\prime} \mathrm{S}, 42^{\circ} 39^{\prime} \mathrm{W}$ (USBGN, 1963). December, 1985. UFMG. $C$. subflavus.

98. Fazenda Triângulo Formoso, Buritizeiros, not located. Here are employed the geographical coordinates of Buritizeiros, $17^{\circ} 21^{\prime} \mathrm{S}, 44^{\circ} 58^{\prime} \mathrm{W}$ (USBGN, 1963). C. Encarnação (col.), October, 1987. UFMG. C. subflavus.

99. Itaobin, $16^{\circ} 33^{\prime} \mathrm{S}, 41^{\circ} 30^{\prime} \mathrm{W}$ (CBM; IBGE, 1972). C.A.M.P. [Unknown acronym] (col.), October, 1980. UFMG. C. vivoi.

100. Itinga (TELEMIG), $16^{\circ} 36^{\prime} \mathrm{S}, 41^{\circ} 46^{\prime} \mathrm{W}$ (USBGN, 1963). Valdemar (col.), June, 1987. UFMG. C. vivoi.

101. Jequitinhonha (TELEMIG), $16^{\circ} 26^{\prime} \mathrm{S}, 41^{\circ} 00^{\prime} \mathrm{W}$ (USBGN, 1963). Valdemar (col.), May, 1987. UFMG. C. vivoi.

102. Lagoa da Pampulha, Belo Horizonte, $19^{\circ} 54^{\prime}$ S, $43^{\circ} 55^{\prime} \mathrm{W}$ (collector). I.N.E.R.U. [Unknown acronym] (col.), July, 1992. UFMG. C. subflavus.

103. Lagoa Santa, $19^{\circ} 37^{\prime} \mathrm{S}, 43^{\circ} 53^{\prime} \mathrm{W} ; 760 \mathrm{~m}$ (USBGN, 1963) [includes Sítio no bairro Quebra, Lagoa Santa]; type locality of $C$. subflavus. A. Langguth (col.). UFPB. J.T. Reinhardt (col.), June-July, 1851. BMNH. C. subflavus, C. scotti.

104. Mata do Edésio, $8 \mathrm{~km}$ NW Nova Ponte, Nova Ponte, $19^{\circ} 07^{\prime} 50^{\prime \prime} \mathrm{S}, 47^{\circ} 44^{\prime} 22^{\prime \prime} \mathrm{W}$; $854 \mathrm{~m}$ (collector). L.P. Costa (col.), June, 1998. UFMG. C. subflavus.

105. Mata do Eixo, Canteiro de Obras da CEMIG (Barragem Nova Ponte), Uberlândia, not located. Here are employed the geographical coordinates of Uberlândia, $18^{\circ} 55^{\prime} \mathrm{S}, 48^{\circ} 16^{\prime} \mathrm{W}$ (USBGN, 1963). L.F.B.M.S. [unknown acronym] (col.), October, 1987. UFMG. C. subflavus.

106. Mata do João Lindolfo, $8 \mathrm{~km}$ NW Nova Ponte, Nova Ponte, $19^{\circ} 07^{\prime} 10^{\prime \prime} \mathrm{S}, 47^{\circ} 43^{\prime} 53^{\prime \prime} \mathrm{W}$; $706 \mathrm{~m}$ (collector). L.P. Costa (col.), June, 1998. UFMG. C. subflavus.

107. Ouro Preto, $20^{\circ} 17^{\prime} \mathrm{S}, 43^{\circ} 30^{\prime} \mathrm{W}$ (USBGN, 1963). Severino (col.), July, 1979. UFMG. C. subflavus.

108. Parque Acangau, Paracatú, not located. Here are employed the geographical coordinates of Paracatú, $17^{\circ} 13^{\prime} \mathrm{S}, 46^{\circ} 52^{\prime} \mathrm{W}$ (USBGN, 1963). P.S. Oliveira (col.), M.N. Paes, April, 1989. UnB. C. scotti.

109. Parque Estadual do Rio Doce (= Parque Florestal Estadual do Rio Doce), $19^{\circ} 32^{\prime} \mathrm{S}$, $42^{\circ} 32^{\prime} \mathrm{W}$ (Vanzolini, 1992) [includes Parque Estadual do Rio Doce, Coronel Fabriciano]. Severino (col.), February, 1978. J.R. Stallings (col.), November, 1985; March, 1986. UFMG. C. subflavus.

110. Parque Estadual do Rio Doce, $13 \mathrm{~km} \mathrm{E}$ Marliéria, $19^{\circ} 34^{\prime} \mathrm{S}, 42^{\circ} 39^{\prime} \mathrm{W} ; 300 \mathrm{~m}$ (collector) [includes Parque Estadual do Rio Doce, Marliéria]. L. Paulo (col.), December, 1986. C. subflavus.

111. Parque Estadual do Rio Preto, $15 \mathrm{~km}$ S São Gonçalo do Rio Preto, São Gonçalo do Rio Preto, $18^{\circ} 09^{\prime} \mathrm{S}, 43^{\circ} 23^{\prime} \mathrm{W}$; $950 \mathrm{~m}$ (collector). L.P. Costa (col.), Y. Leite (col.), July, 1996. C. subflavus.

112. Parque Nacional Grande Sertão Veredas, $15^{\circ} 16^{\prime} \mathrm{S}, 45^{\circ} 52^{\prime} \mathrm{W}, 700-800 \mathrm{~m}$ (collector). A.P. Carmignotto (col.), October, 2001. MZUSP. C. marinhus.

113. Prados, Biquinha, $21^{\circ} 03^{\prime} \mathrm{S}, 44^{\circ} 05^{\prime} \mathrm{W}$ (USBGN, 1963). C. Valle (col.), January, 1979. UFMG. C. subflavus.

114. Reserva do Jacob, Nova Ponte, not located; here are employed the geographical coordinates of Nova Ponte, $19^{\circ} 08^{\prime} \mathrm{S}, 47^{\circ} 40^{\prime} \mathrm{W}$ (USBGN, 1963). R. Moura and E. Sabato (cols.), March, 1996. C. maracajuensis.

115. Riacho Mocambinho, Jaíba, $15^{\circ} 06^{\prime} \mathrm{S}, 44^{\circ} 03^{\prime} \mathrm{W}$ (collector). J.A. Oliveira (col.). MN. C. vivoi.

116. Ribeirão Contendas, Cristália, $16^{\circ} 43^{\prime} \mathrm{S}$, 42 $52^{\prime} \mathrm{W}$ (USBGN, 1963). April, 1987. UFMG. C. vivoi. 
117. Rio Bagaço, Santa Luzia, not located. Here are employed the geographical coordinates of Santa Luzia, $19^{\circ} 46^{\prime} \mathrm{S}, 43^{\circ} 51^{\prime} \mathrm{W}$ (USBGN, 1963). Severino (col.), January, March, 1979. UFMG. C. subflavus.

118. Usina Hidroelétrica de Igarapava, Conquista, $20^{\circ} 00^{\prime} \mathrm{S}, \quad 47^{\circ} 35^{\prime} \mathrm{W}$ (UFMG database). E. Sábato (col.). UFMG. C. scotti, C. subflavus.

119. Val da Lagoa, Serra do Cipó, not located. Here are employed the geographical coordinates of Rio Cipo, a stream that dissects the Serra do Cipó, $19^{\circ} 14^{\prime} \mathrm{S}, 43^{\circ} 33^{\prime} \mathrm{W}$ (USBGN, 1963). C. Valle (col.), julho de 1979. UFMG. C. subflavus.

120. Vargem do Retiro, Ribeirão Mascates, Parque Nacional da Serra do Cipó, 800m; not located. Here are employed the geographical coordinates of Ribeirão Mascate, $19^{\circ} 20^{\prime} \mathrm{S}, 43^{\circ} 36^{\prime} \mathrm{W}$ (USBGN, 1963). MN. C. subflavus.

\section{Paraíba}

121. Corredor São João-Fazenda Pacatuba, lado W Mata Pacatuba, Sapé, ca. $07^{\circ} 02^{\prime} \mathrm{S}$, $35^{\circ} 09^{\prime} \mathrm{W}$; type locality of C. langguthi. A. Langguth (col.), December, 1995. MN. C. langguthi.

122. João Pessoa, $07^{\circ} 06^{\prime} \mathrm{S}, 34^{\circ} 41^{\prime} \mathrm{W}$ (USBGN, 1963) [includes Campus Universitário; Mata em Cruz das Armas, próximo a Cimepar; Mata próxima ao Conjunto dos Bancários; Mata Sul UFPB; Mata do Timbó, ao lado Conjunto dos Bancários]. A.P. Oliveira (col.), August, November, 1979. J. Leite (col.), November, 1980. SUCAM, December, 1980. M.P. Silva (col.), May, 1981. O. Farias (col.), H. Monteiro. A. (col.), January, 1981. D.R. Nogueira (col.), March, 1986. UFPB. C. langguthi.

123. Fazenda Alagamar, $9 \mathrm{~km} \mathrm{~S}$ e $6 \mathrm{~km} \mathrm{E} \mathrm{de}$ Mamanguape, $06^{\circ} 55^{\prime} \mathrm{S}, \quad 35^{\circ} 04^{\prime} \mathrm{W}$ (MEP; IBGE, 1970). A. Langguth (col.), July, 1987. UFPB. C. langguthi.

124. Mata de Pau Ferro, $6 \mathrm{~km}$ de Areia, not located. Here are employed the geographical coordinates of Areia, $06^{\circ} 57^{\prime} \mathrm{S}, 35^{\circ} 41^{\prime} \mathrm{W}$ (USBGN, 1963). A. Langguth (col.), A. Langguth \& L.F. Soares (cols.), April, 1983. UFPB. C. langguthi.

125. Natuba, $07^{\circ} 38^{\prime} \mathrm{S}, 35^{\circ} 34^{\prime} \mathrm{W}$ (USBGN, 1963) [includes Povoado Gito, Sítio Chã do Vento, Sítio F. dos Meiros, Sítio Lagoa da Besta, Sítio Malheiro, Sítio Pedra da Bica, Sítio Quicé,
Sítio Recreio, Sítio São José, Sítio Tauá]. M.P. Silva (col.), May, June, 1982. A. Langguth (col.), SUCAM, October, December, 1982. SUCAM, May, August, October, December, 1982. UFPB. C. langguthi.

126. Pico do Jabre, $18 \mathrm{~km}$ WSW de Teixeira, $07^{\circ} 19^{\prime} \mathrm{S}, 37^{\circ} 23^{\prime} \mathrm{W}$ (MEP; IBGE, 1970). A. Langguth (col.), October, 1984. F. S. Lima (col.), October, 1984. UFPB. C. langguthi.

127. Pirauá, Natuba, $07^{\circ} 36^{\prime} \mathrm{S}, 35^{\circ} 35^{\prime} \mathrm{W}$ (USBGN, 1963) [includes Proximidade Pirauá e Povoado de Pirauá]. M.P. Silva (col.), May, 1982. A. Langguth (col.), October, 1982. SUCAM, October, December, 1982. UFPB. C. langguthi.

128. Salgado de São Felix, $07^{\circ} 21^{\prime} \mathrm{S}, 35^{\circ} 26^{\prime} \mathrm{W}$ (USBGN, 1963) [includes Engenho Govão Fazenda T. do Marinheiro, Sítio Campinas, Sítio Preguiça, Vila Feira Nova]. M.P. Silva (col.), SUCAM, June, 1982. SUCAM, October, 1983. UFPB. C. langguthi.

\section{Pernambuco}

129. Exú, $07^{\circ} 30^{\prime} \mathrm{S}, \quad 39^{\circ} 44^{\prime} \mathrm{W}$ (USBGN, 1963). ABC-FINEP (col.), May, 1972; January, September, October, 1977; January-March, May, 1978. MZUSP. C. langguthi.

130. Fazenda Saco IBA, $6.6 \mathrm{~km}$ NNE de Serra Talhada, $07^{\circ} 59^{\prime} \mathrm{S}, 38^{\circ} 18^{\prime} \mathrm{W}$ (USBGN, 1963). ABC-FINEP (col.), October, 1977. MZUSP. C. langguthi.

131. Macaparana, $07^{\circ} 33^{\prime} \mathrm{S}, 35^{\circ} 29^{\prime} \mathrm{W}$ (USBGN, 1963) [includes Chã do Pau d'Arco, Fazenda Alegre Velho, Fazenda Monte Alegre, Fazenda Monte Alegre Novo, Sítio Bilo, Sítio Cilo, Sítio Fandango, Sítio José Camilo (= Sítio São José Camilo), Sítio Olho d'Água]. A. Langguth (col.), SUCAM, September-November, 1982. SUCAM, September-October, 1983. UFPB. C. langguthi.

132. São Vicente Ferrer, $07^{\circ} 35^{\prime} \mathrm{S}, \quad 35^{\circ} 29^{\prime} \mathrm{W}$ (USBGN, 1963) [includes Engenho Zabelê Sítio Alto do Miro, São Vicente Ferrer]. SUCAM, September, December, 1982. A. Langguth (col.), SUCAM, December, 1982. UFPB. C. langguthi.

133. Sítio Mata Verde, Buíque. Not located; here are employed the geographical coordinates of Buíque, $08^{\circ} 37^{\prime} \mathrm{S}, 37^{\circ} 09^{\prime} \mathrm{W}$ (USBGN, 1963). Serviço Nacional de Peste (SNP), November, 1977. MZUSP. C. langguthi. 


\section{Piauí}

134. Arara, $04^{\circ} 50^{\prime} \mathrm{S}, 40^{\circ} 55^{\prime} \mathrm{W}$ (USBGN, 1963); 500-800m (collector). E. Snethage (col.), February, 1925. FMNH. C. langguthi.

135. Estação Ecológica de Uruçuí-Una, $08^{\circ} 50^{\prime} \mathrm{S}$, $44^{\circ} 10^{\prime} \mathrm{W}$ (collector). A.R. Percequillo, A.P. Carmignotto, M. Vivo, E. Hingst-Zaher (cols.), February-April, 2000; July, 2000; January-February, 2001. MZUSP. C. scotti.

\section{São Paulo}

136. Avanhandava, $21^{\circ} 28^{\prime} \mathrm{S}, 49^{\circ} 57^{\prime} \mathrm{W}$ (USBGN, 1963). E. Garbe (col.), July, 1911. MZUSP. C. subflavus.

137. Barreiro Rico (= Fazenda Barreiro Rico), Santa Maria da Serra, $22^{\circ} 45^{\prime} \mathrm{S}, 48^{\circ} 09^{\prime} \mathrm{W}$ (Vanzolini, 1992). E. Dente (col.), ex BIOLaboratório de Citogenética de Vertebrados, August, 1980. UFPB. C. subflavus.

138. Campininha, Mogi Guaçu, Res. Biol. de Mogi Guaçu, $22^{\circ} 17^{\prime} \mathrm{S}, 47^{\circ} 09^{\prime} \mathrm{W}$ (P.E. Vanzolini, MZUSP archives). M. de Vivo (col.), July, 1981. MZUSP. C. subflavus.

139. Cássia dos Coqueiros, $21^{\circ} 17^{\prime} \mathrm{S}, 47^{\circ} 10^{\prime} \mathrm{W}$ (USBGN, 1963). Ex-Faculdade de Medicina Ribeirão Preto, August, 1963. MZUSP. C. subflavus.

140. Dois Córregos, $22^{\circ} 22^{\prime} \mathrm{S}, 48^{\circ} 21^{\prime} \mathrm{W}$ (USBGN, 1963). O. Della Serra (col.), August, 1950. MZUSP. C. subflavus.

141. Franca, $20^{\circ} 32^{\prime} \mathrm{S}, 47^{\circ} 24^{\prime} \mathrm{W}$ (USBGN, 1963). Dreher (col.), October-November, 1902. MZUSP. C. subflavus.

142. Itapetininga, $23^{\circ} 35^{\prime} \mathrm{S}, 48^{\circ} 03^{\prime} \mathrm{W}$ (USBGN, 1963). E. Dente (col.), Instituto Adolpho Lutz (col.), May, 1969; February, April, 1972. UFMG, MZUSP. C. subflavus.

143. Ituverava, $20^{\circ} 20^{\prime} \mathrm{S}, 47^{\circ} 47^{\prime} \mathrm{W}$ (USBGN, 1963). E. Garbe (col.), July, 1911. MZUSP. C. subflavus.

144. Salto de Pirapora, Bairro da Ilha, $23^{\circ} 43^{\prime} \mathrm{S}$, $47^{\circ} 37^{\prime} \mathrm{W}$ (P.E. Vanzolini, MZUSP archives). Faculdade de Higiene e Saúde Publica-USP, May, 1968. MZUSP. C. subflavus.

\section{SERGIPE}

145. Fazenda Capivara, $7 \mathrm{~km}$ SE de Brejo Grande, Brejo Grande, $10^{\circ} 29^{\prime} \mathrm{S}, 36^{\circ} 26^{\prime} \mathrm{W}$ (collector). A. Langguth (col.) MN. C. vivoi.

\section{Tocantins}

146. Margem direita do Rio da Palma, a montante da confluência dos rios da Palma e Paranã, Paranã, $12^{\circ} 35^{\prime} \mathrm{S}, 47^{\circ} 52^{\prime} \mathrm{W}$ (collector). A.R. Percequillo (col.), 2001. MZUSP C. scotti.

\section{PARAGUAY}

\section{Amambay}

147. $28 \mathrm{~km} \mathrm{SW}$ de Pedro Juan Caballero, $22^{\circ} 43^{\prime} \mathrm{S}$, 555'' W (CBM; IBGE, 1972). T. W. Nelson (col.), January, 1977. UMMZ. C. maracajuensis.

148. Parque Nacional Cerro Cora, ca. $22^{\circ} 45^{\prime} \mathrm{S}$, $55^{\circ} 58^{\prime} \mathrm{W}$ (collector) [includes Parque Nacional Cerro Corá, Aquidaban, sendero NE de pista de avión and Parque Nacional Cerro Cora, near Rio Aquidaban, aprox. $7 \mathrm{~km}$ from casa de Adm.]. D.E. Wilson and M. Ludlow (cols.), February, 1982. USNM. C. maracajuensis.

\section{Caaguazu}

149. Estancia San Ignacio, $24 \mathrm{~km}$ NNW Carayao, $25^{\circ} 00^{\prime} \mathrm{S}, 56^{\circ} 30^{\prime} \mathrm{W}$ (CBM; IBGE, 1972). P. Myers (col.), July, 1979. UMMZ. C. maracajuensis.

\section{Canendiyu}

150. $13.3 \mathrm{~km} \mathrm{~N}$ de Curuguaty, by road, $24^{\circ} 22^{\prime} \mathrm{S}$, $55^{\circ} 42^{\prime} \mathrm{W}$ (CBM; IBGE, 1972). P. Myers (col.), July, 1979. UMMZ. C. maracajuensis.

151. Villa Igatimi [also spelled Ygatimí or Igatimí], $24^{\circ} 05^{\prime} \mathrm{S}, 55^{\circ} 30^{\prime} \mathrm{W}, 151 \mathrm{~m}$ (USBGN, 1957). J. Contreras (col.). MLP. C. maracajuensis.

\section{CONCEPCION}

-. $\quad 28 \mathrm{~km} \mathrm{~S}$ junction route 3 and route 5, on route 3, not located. P. Myers (col.), July, 1972. MVZ. C. scotti.

\section{Cordillera}

152. $1.6 \mathrm{~km} \mathrm{~S}$ Tobatí, $25^{\circ} 16^{\prime} \mathrm{S}, 57^{\circ} 04^{\prime} \mathrm{W}$ (collector). P. Myers (col.), October, 1972; MVZ. July, 1978; UMMZ. C. scotti.

153. $20 \mathrm{~km} \mathrm{~N}$ Altos, $25^{\circ} 04^{\prime} \mathrm{S}, 57^{\circ} 03^{\prime} \mathrm{W}$ (MVZ database). P. Myers (col.), July, 1973. MVZ. C. scotti.

\section{Paraguari}

154. Sapucay [also spelled Sapucaí], $25^{\circ} 40^{\prime} \mathrm{S}$, $56^{\circ} 55^{\prime} \mathrm{W}$ (USBGN, 1957). W. Foster (col.), July, 1902; BMNH. July, 1903; MZUSP. August-September, 1902; USNM. C. maracajuensis, C. scotti. 
155. Tacuati, [Aca Poi] $23^{\circ} 27^{\prime} \mathrm{S}, \quad 56^{\circ} 35^{\prime} \mathrm{W}$ (USBGN, 1957). "Ground set-edge of canadon near growth of Bromelia balansae" (collector). C. Wharton (col.), April, 1950. USNM. C. maracajuensis.

\section{SAn PEDro}

156. Ganadera La Carolina, $1.5 \mathrm{Km}$ SW las casas, $24^{\circ} 06.619^{\prime} \mathrm{S}, 5^{\circ} 25.624^{\prime} \mathrm{W}$ (collector). G. D’Elía (col.), C. Manchini (col.), March, 2001. GD. C. maracajuensis.

\section{PERU}

Puno

157. Rio Heath, Aguas Claras Camp, $12^{\circ} 57^{\prime} 32^{\prime \prime} \mathrm{S}$, $68^{\circ} 54^{\prime} 08^{\prime \prime} \mathrm{W}, 190 \mathrm{~m}$ (collector). L.H. Emmons (col.), June, 1992. USNM. C. maracajuensis. 

Complete lists of all issues of the Novitates and the Bulletin are available at World Wide Web site http://library.amnh.org/pubs. Inquire about ordering printed copies via e-mail from scipubs@amnh.org or via standard mail from: American Museum of Natural History, Library-Scientific Publications, Central Park West at 79th St., New York, NY 10024. TEL: (212) 769-5545. FAX: (212) 769-5009. 